\title{
Surfacing the Submerged State: Operational Transparency Increases Trust in and Engagement with Government
}

Ryan W. Buell

Ethan Porter

Michael I. Norton

Working Paper 14-034 


\section{Surfacing the Submerged State: Operational Transparency Increases Trust in and Engagement with Government}

\section{Ryan W. Buell}

Harvard Business School

Ethan Porter

George Washington University

Michael I. Norton

Harvard Business School

Working Paper 14-034

Copyright (C) 2013, 2014, 2015, 2016, 2017, 2018, 2019 by Ryan W. Buell, Ethan Porter, and Michael I. Norton. 


\title{
Surfacing the Submerged State: Operational Transparency Increases Trust in and Engagement with Government
}

\author{
Ryan W. Buell ${ }^{1}$, Ethan Porter $^{2}$, and Michael I. Norton ${ }^{3}$ \\ Harvard Business School ${ }^{1,3}$, George Washington University ${ }^{2}$ rbuell@hbs.edu ${ }^{1}$, \\ evporter@email.gwu.edu², mnorton@hbs.edu $\left.{ }^{3}\right]$
}

\begin{abstract}
:
Problem definition: As trust in government reaches historic lows, frustration with government performance approaches record highs. Academic/practical relevance: We propose that in co-productive settings like government services, peoples' trust and engagement levels can be enhanced by designing service interactions to allow them to see the often-hidden work - via increasing operational transparency - being performed in response to their engagement. Methodology and results: Across three experimental studies, conducted in the field and lab, we find that surfacing the "submerged state" through operational transparency impacts citizens' attitudes and behavior. Study 1 leveraged proprietary data from a mobile phone application developed by the City of Boston, Massachusetts, through which residents can submit service requests; the city's goal was to increase engagement with the app. Users who received photos of government addressing their service requests submitted $60 \%$ more requests and in $38 \%$ more categories over the ensuing 13 months than users who did not receive such photos. These significant gains in engagement persisted for 11 months following users' initial exposure to operational transparency, and were highest for users who previously had experienced government to be at least moderately responsive to their past requests. In Study 2, residents of Boston who interacted with a website that visualized both service requests (e.g., potholes and broken street lamps) and efforts by the city's government to address those requests became $14 \%$ more trusting and $12 \%$ more supportive of government. Moreover, residents who received additional transparency into the growing backlog of service requests that government was failing to fulfill - revealing government to be less responsive - were no more nor less trusting and supportive of government than residents who received no transparency. Study 3 replicated findings from the first two studies, tracing out the mechanisms linking operational transparency and responsiveness to trust and willingness to engage. Operational transparency increases trust and engagement by two causal pathways - through consumers' increased perceptions of effort by the government and through increased perceptions that engaging with it is impactful. Responsiveness increases feelings of personal efficacy, which boosts willingness to engage both directly and indirectly through the other causal paths. Managerial implications: Taken together, our results suggest that showing more work performed by the organization - via operational transparency - encourages customers to do more work themselves, results with implications for the design of a broad array of co-productive services where operations are hidden and consumer trust and engagement is critical.
\end{abstract}

[Keywords: Government services, behavioral operations, co-production, operational transparency, trust, engagement]

\section{Introduction}

Governments are massive service operations; in the United States in 2019 alone, for example, the federal, state, and local government employed more than 22 million people - 14\% of the working-age population and provided service for 329 million people (U.S. Bureau of Labor Statistics 2019). Moreover, like service offerings in a broad array of domains, government services are co-produced; governments rely on their citizen "customers" to productively engage in the service delivery process: voting, paying taxes, following laws, and contributing to the public discourse (Roels 2014). However, in the United States, as in many parts 
of the world, trust in government has been in decline for more than half a century. For example, in 1958, $73 \%$ of Americans reported that they trusted their government at least most of the time; by 2019, that percentage had fallen to 17\% (Pew Research Center 2019). Lack of trust in government presents serious challenges to its effectiveness, undermining support for the governing process and reducing civic engagement (Jennings and Stoker 2004).

In political science, explanations for the decline in trust in government include political scandals (Bowler and Karp 2004), foreign policy failures (Hetherington and Husser 2012), citizens' low evaluations of government performance (Citrin 1974), and, more broadly, the public salience of ineffective and unpopular policies and politicians (Miller 1974). We propose that the public's deteriorating relationship with government - manifested in declining levels of trust, support, and engagement - may arise in part from what is not publicly salient. Government operations are typically hidden from public view, such that citizens often are unable to observe the work involved in delivering government service: citizens follow helpful traffic signs, for example, and rarely think about the government agency and employees responsible for their installation. This "submerged state" can result in citizens failing to credit government for the work it performs (Mettler 2011). We suggest that making government services more operationally transparentrevealing the hidden work that government performs and surfacing the submerged state - can improve attitudes towards government and increase citizens' engagement.

Motivating trust and engagement are crucial challenges in a broad array of people-centric operations settings, both within and outside the public sector. From healthcare to education to financial services, success in many service contexts depends on whether consumers trust the organization with which they are interacting and whether they are willing to meaningfully engage with it. While a growing body of management research documents the benefits of transparency on perceptions of organizations, demonstrating that customers reward firms that make their operations transparent and punish those that do not (Buell et al. 2017, Buell and Norton 2011, Kalkanci et al. 2015, Kraft et al. 2018, Mohan et al. 2019), this prior work has not explored whether operational transparency can shape people's perceptions in ways that make them more willing to engage in co-production. Despite the many differences among for-profit and government operations, we propose, and our results suggest, that when a government that is at least moderately responsive to citizen requests increases the transparency of its operations - literally, showing its work - those citizens will trust and engage with government more. Moreover, we explore the underlying mechanisms driving these effects - that operational transparency increases perceptions of the effort expended by government, as well as perceptions that engaging with government is impactful - and argue that the same dynamics exist in a broad swath of co-productive services, where fostering trust and meaningful engagement is determinative of a high-quality outcome. 


\section{Trust, engagement, and operational transparency}

Trust and engagement are inextricably linked. In the operations literature, trust is defined as the willingness to voluntarily behave in a way to accept vulnerability due to the uncertain behavior of another, based upon the expectation of a positive outcome (Özer and Zheng 2019). Engagement is a voluntary behavior enacted in anticipation of a positive outcome, but in settings where the outcome will be co-produced, taking the first step is an act of vulnerability, since it is unclear whether one's engagement will be reciprocated, and whether a positive outcome will manifest in turn.

These dynamics can be especially challenging in co-productive settings like government, where so much of the work government performs escapes the awareness of the people who consume its services. For example, in a recent survey, $60 \%$ of citizens who claimed the Home Mortgage Interest Deduction denied that they "used a government social program," with large numbers of beneficiaries of student loans, veterans' benefits, Medicaid, Medicare and food stamps claiming the same (Koch and Mettler 2012). Theorists have proposed that policy designs that make government effort more visible elevate citizens' awareness of those efforts, while those that obscure such efforts leave citizens oblivious to the government's role (Pierson 1993). Problematically, however, even in cases where citizens are aware that the government is engaged in service delivery, their opportunities to observe it in action may be somewhat limited. For example, residential mail delivery and trash collection often occur during working hours, when homeowners may be away. Traffic is typically rerouted around major government-funded construction projects, and temporary work zones, including those involving government resources, are generally cordoned off from pedestrians. When service delivery is obscured from customers, they may lack the ability to intuit the work involved in the process (Neely et al. 2011, Parasuraman et al. 1985), hindering their perceptions of its value - and perhaps, by extension, their trust in the organization.

A growing body of research documents the benefits of operational transparency: revealing the work performed for customers has been shown to shape perceptions of organizations in positive ways. Customers consider operationally transparent services to be more valuable, owing to a heightened understanding and appreciation of the effort involved in delivering the service (Buell et al. 2017, Buell and Norton 2011). Similarly, observing that time has been devoted to the production of a product or service increases ratings of its quality (Chinander and Schweitzer 2003, Kruger et al. 2004), and observing effortful processes increases customer satisfaction as well as feelings of reciprocity and gratitude (Bray 2018, Kraft et al. 2018, Mohr and Bitner 1995, Morales 2005).

We suggest that, by extension, operational transparency may additionally engender trust. Indeed, Özer and Zheng (2016) describe how business process design is an important building block of trust, highlighting 
reputation and feedback systems, as well as assistance processes as examples - innovations that may be similar in effect to operational transparency. Reputation and feedback systems enable under-informed parties to learn from the past experiences of others, building trust by facilitating the screening out of unreliable trading partners (Özer and Zheng 2019), while assistance processes such as information sharing have been shown to build trust even among parties whose incentives may not otherwise be fully aligned (Özer et al. 2018). In many co-productive service contexts such as government, information asymmetries abound; customers may be uncertain about the extent of the (hidden) effort of the organizations that serve them and of the likelihood that the effort they expend by engaging will be reciprocated. Consequently, operational transparency that closes the loop with customers, providing direct feedback that shows the work that was performed in response to their engagement, or that shares information about the otherwise-hidden work being performed in service of others, could be a viable pathway to engendering trust. Indeed, since visual information can dominate other types of information in forming perceptions (Ambady and Rosenthal 1993, Benjamin and Shapiro 2009, Rule and Ambady 2008, Tsay 2014), operational transparency may play an especially powerful role in influencing trust in government, a context that's not only rife with information asymmetries, but also one that frequently teems with conflicting sources of information.

To the extent operational transparency induces higher levels of trust, it may also promote an increased willingness to engage with the operation. A growing body of recent research in a broad array of operating contexts has demonstrated how transparency can serve as a lever for influencing how people engage with operations. For example, providing transparency into different facets of an operation has been shown to promote process compliance (Staats et al. 2016), influence rates of bias and discrimination (Cui et al. 2018, Mejia and Parker 2018), foster sustainable purchase and consumption behaviors (Buell, Mariadassou, et al. 2017, Buell and Kalkanci 2019, Kalkanci et al. 2015) inform customer product selection (Buell and Choi 2019), shape evaluations (Bray 2018), and promote donations and sales (Kraft et al. 2018, Mejia et al. 2019, Mohan et al. 2019). However, no previous work has explored how operational transparency influences consumers' co-productive behavior - their propensity to engage in the operation itself (Roels 2014). Here, we offer an intervention in which showing more work performed by the organization - via operational transparency - encourages customers to do more work themselves.

To the extent that customers in co-productive settings simultaneously serve as both consumers and producers, it seems possible that operational transparency may exert the same influence on would-be coproducers that it does on the consumer role played by customers and the producer role played by employees. In particular, if transparency engenders trust, and in turn, a willingness to engage in much the same way that transparency increases customers' perceptions of an organization's effort, feelings of appreciation, and perceived value (Buell and Norton 2011), it may similarly enact in customers the same psychological 
processes driving employees to expend effort in operationally transparent service contexts. Just as seeing the beneficiaries of one's efforts makes work feel more meaningful and appreciated, increasing an employee's willingness to engage in it (Buell et al. 2017, Grant 2007, Grant et al. 2007), seeing the impact of one's own engagement through operational transparency may help individuals feel their engagement is more meaningful and engender positive attitudes toward themselves for engaging.

Although these dynamics are likely to exist in a broad array of co-productive settings, we conduct the present study in the context of government - a domain where low levels of engagement have long been an object of inquiry in political science research and practice (Campbell et al. 1960, Lewis-Beck et al. 2008, Rosenstone and Hansen 1993, Schlozman et al. 2012). In the United States, despite many efforts to engage citizens, participation levels remain stubbornly low (Pew Research Center 2019). Low levels of participation affect not just politics (Skocpol 2003), but bleed into civic life as well (Putnam 2000). For their part, political campaigns spend enormous sums to try and coax voters to go to the polls. For example, in 2016, campaign spending totaled $\$ 6.5$ billion (Ingraham 2017), but in that same election, the level of U.S. political participation ranked 26th of 32 OECD nations (Desilver 2017). By extending research on operational transparency into government contexts - where engagement and trust are declining, and services are habitually hidden - the present research not only has practical implications for government policy and service design, but also contributes in four primary ways to the broader literature on coproduction in people-centric operations.

First, although prior research has investigated the effects of showing the hidden work taking place within an operation on customer perceptions and purchase behavior, the present work is the first to directly investigate whether operational transparency has the capacity to drive increased engagement with an organization over time. Leveraging two years of proprietary data from a mobile application through which Boston residents submit service requests (e.g. potholes, burned-out streetlights, graffiti, etc.) to the city government, we explore how the provision of operational transparency - showing the hidden work involved in fulfilling a resident's request - affects subsequent levels of engagement. Residents who were shown images of the work government performed in response to their requests engaged with the app at significantly higher rates over the ensuing 13 months, submitting 60\% more requests, and in $38 \%$ more categories gains in engagement that enabled the City of Boston to allocate fewer employees to identifying problems and more employees to solving them. Moreover, residents who experience operational transparency continue to submit more requests, and in a broader array of categories, eleven months after their initial exposure. These results highlight that the incorporation of operational transparency into service designs has the potential to affect not just short-term perceptions and behaviors, but longer-term engagement as well. 
Second, we investigate the extent to which the provision of operational transparency can engender trust in and support for government. In the government domain, trust is a well-established driver of civic engagement, but it is also notoriously difficult to influence. In our research, Boston-area residents who interacted with a website that visualized public service requests, and efforts by the city's government to resolve them, became $14 \%$ more trusting and $12 \%$ more supportive of government. Third, we identify an important boundary condition that influences the effect of operational transparency on engagement and trust: the degree of responsiveness of the transparent organization. In our studies, we find that operational transparency only leads to increased engagement and trust when the government is at least moderately responsive.

Fourth, we explore the underlying psychological mechanisms linking operational transparency and government responsiveness to levels of trust and willingness to engage. We find that in co-productive settings like government, where the consumer is both a beneficiary and a producer of the service being delivered (Roels 2014), operational transparency activates similar causal pathways to those it has separately been shown to produce among customers and employees. Much like its effects on customers established in previous literature (Buell and Norton 2011), we find that operational transparency increases co-producers' perceptions that the government exerts effort, which causes them to appreciate, trust, and support the government more. And, similar to its documented effects on employees of providing transparency to the beneficiaries of their efforts (Buell et al. 2017, Grant 2007, Grant et al. 2007), we find that operational transparency can increase co-producers' perceptions that engaging with the government is impactful, which leads to feelings of positivity directed toward themselves for engaging, thereby increasing their willingness to engage. And consistent with the moderating effects of responsiveness described above, we find that responsiveness promotes feelings of efficacy, which increases willingness to engage both directly, and indirectly by increasing perceptions that the government is an effortful partner, with which it is impactful to engage. Owing to the ubiquity of service settings where successful outcomes depend on the consumer's level of trust and willingness to engage, and the fact that the dynamics we document as drivers of trust and engagement exist in many settings, we believe the present research speaks not only to government services - an important sector in its own right - but to a much broader array of co-productive contexts.

\section{Presentation of studies}

Through three field and lab studies examining behavioral and perceptual measures, we explore the effects of operational transparency and government responsiveness on citizen trust and engagement, and examine underlying mechanisms. Study 1 was conducted in the field in collaboration with the City of Boston, and it

follows 21,786 residents of the City of Boston engaging with a smartphone app over a two-year period to 
document the effects of operational transparency on resident engagement. Study 2 brought Boston-area residents into a behavioral lab, where they engaged with a website that visualized actual service requests submitted to the city government, and the government's efforts to resolve them, to investigate how operational transparency and government responsiveness influence feelings of trust and support. Study 3 is a large-scale online experiment designed to map the mechanisms linking operational transparency and responsiveness to trust and engagement: citizen's perceptions of increased effort by government and an increased feeling of their own impact of engaging. In the presentation of each of the studies that follow, the paper reports how sample sizes were determined, all data exclusions, all manipulations, and all measures collected (Simmons et al. 2012).

\subsection{Study 1: Operational transparency, responsiveness, and citizen engagement}

As an initial investigation of whether operational transparency could promote increased engagement, we relied upon proprietary data from the city of Boston, Massachusetts. Between October 1, 2013 and October 27, 2015, Boston residents submitted service requests to the government through "Citizen's Connect," a smart phone application that transmits inquiries for resolution to the city's Public Works Department. Resident-submitted descriptions at the time of this study included: "broken playground equipment needs a bolt;" "annual enormous pothole at the end of the Westbound exit ramp, left lane;" and "graffiti on Allied Waste dumpster." Each submission captured by the application included a photo of the issue, a title, a description, and an approximate address verified by the phone's GPS. Historically, residents who submitted service requests through Citizen's Connect received a "closed" badge appended to their original submission when the issue was resolved - a "text only" notification. But on September 25, 2014, the city launched a new version of the application that allowed for "text and transparency" notifications when an issue was resolved, that included images of the completed work performed and/or the city workers that performed it when the request was closed. We exploit the variation in this difference in transparency to investigate operational transparency's impact on resident engagement.

3.1.1 Design and procedure. The new version of Citizen's Connect, which was automatically pushed to residents' phones through the iOS and Android platforms, diffused rapidly, achieving more than a $90 \%$ penetration rate within three months. Experiencing operational transparency required residents both to have the new version of Citizen's Connect and to make a service request that was closed by a Public Works team that happened to post a photo. This combination of requirements resulted in a staggered diffusion of the treatment that facilitated our identification strategy (Figure 1). Our strategy depends on the as-if random quality of individual Public Works teams' decisions to post, or not post, a photo; critically, conversations with the officials responsible for Citizen's Connect revealed that teams posted photos with no guidance 
from their supervisors and without visibility into the identities of the residents who submitted each request. These officials indicated that the primary factor influencing whether a request was resolved with a photo was whether the crew who responded had a version of the city worker app that supported photos at the time of their response. We test the robustness of our results to this assumption in Section 3.1.8 below.

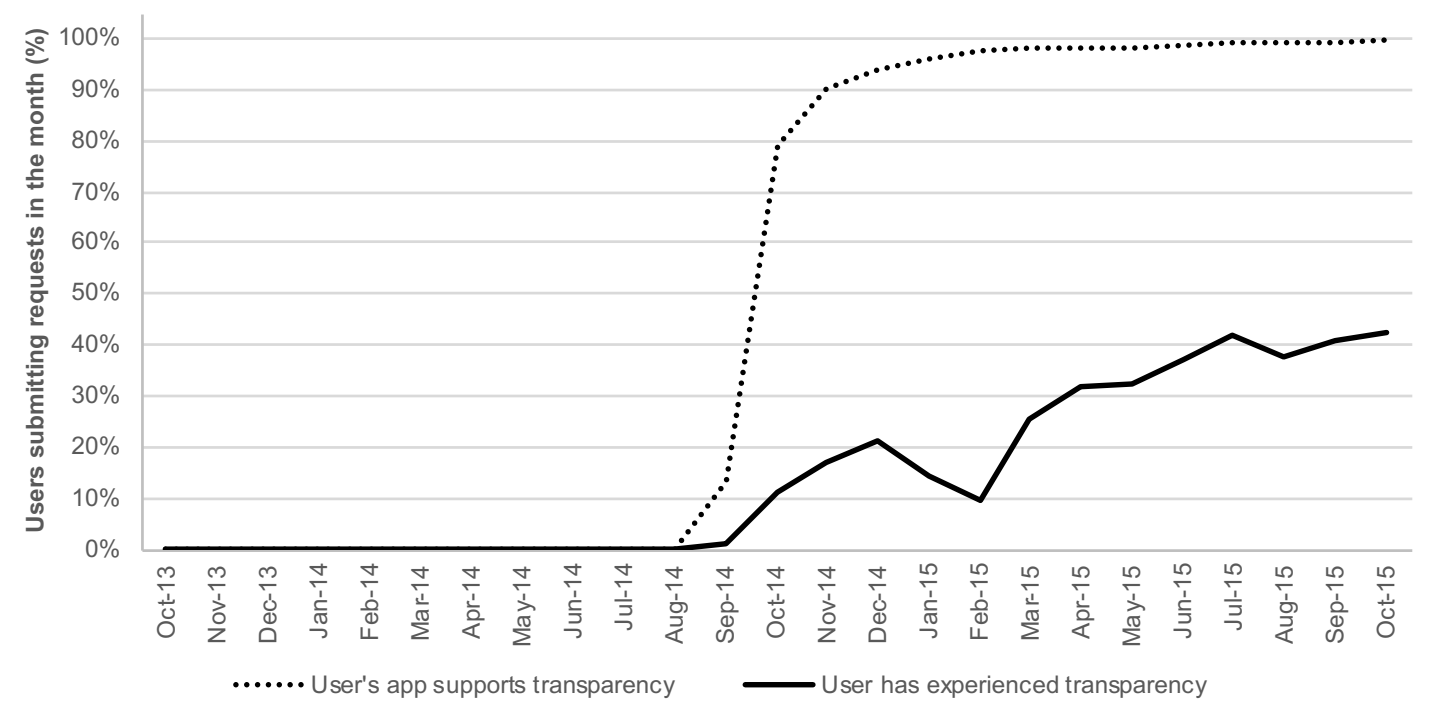

Figure 1: Percentage of reports submitted by users who had experienced operational transparency over time as well as diffusion of Version 3.10.1890 of the application, which supported operational transparency (Study 1). The new version of the app was launched on September 25, 2014, and it diffused rapidly. Note that periods of decline in the percentage of users who had previously experienced operational transparency reflect periods of time during which the total number of Citizen's Connect users increased.

We conceptualized transparency as a persistent treatment variable: once a resident had observed an image of requested work being performed, we counted that resident as having received the operational transparency treatment. Figure 2 illustrates what residents experienced in the text-only baseline and operationally transparent conditions. Panel A is representative of the baseline condition, in which a user has submitted a picture of a local sidewalk that has not been shoveled after a snowstorm. After the request is fulfilled and the sidewalk is shoveled, the user receives her original picture back, along with a blue tag noting that the case has been closed and a textual message indicating that the sidewalk has been shoveled. Contrast that with Panel B, which displays an example of the operationally transparent condition - in addition to the blue tag and textual notification, the city provides the user a photo of the work that was performed in accordance with their request - the shoveled sidewalk. 


\section{Submission}

A. Non-transparent Upon closure, resident sees only the photo he or she originally submitted, along with a text description of how the issue was resolved.

\section{B. Transparent \\ Upon closure, resident sees the photo he or she originally submitted, a text description of how the issue was resolved, and a photo uploaded by the government employee, of the resolved issue.}

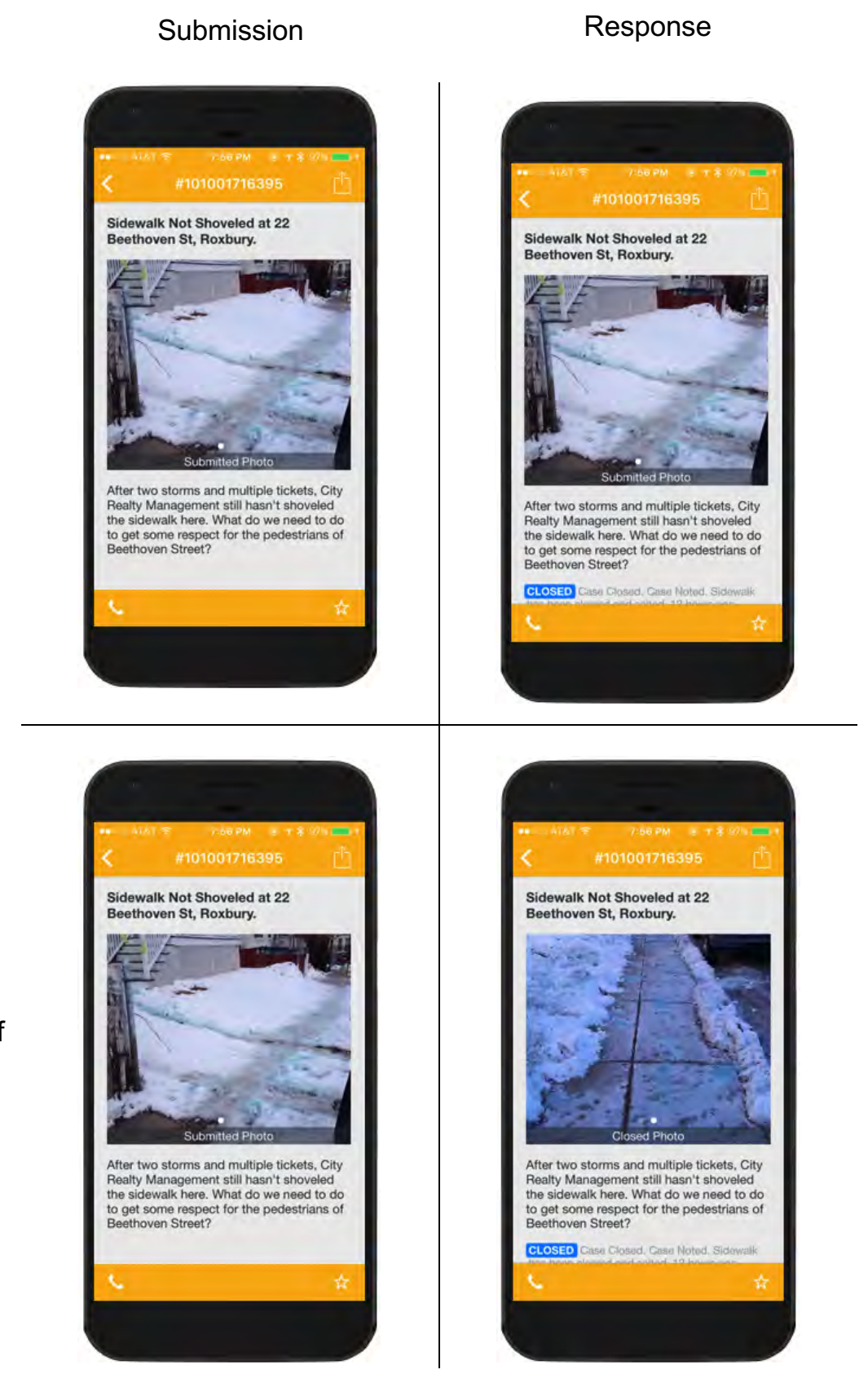

Figure 2: Screenshots from the Citizen's Connect application in the baseline and operationally transparent conditions (Study 1). When an issue was resolved, residents in both conditions received a textual notification that the work had been completed, but those experiencing operational transparency additionally received an image of the work that had been performed.

3.1.2. Participants. During our period of analysis, 23,302 residents submitted service requests to the Boston city government. We focused on the requests submitted by the 21,986 residents who submitted at least one service request without transparency, to provide at least some basis for comparison in our fixed effects panel analyses. Furthermore, we conducted our primary analyses on a sub-sample of the data $(N=$ 
21,786 ) that excluded users who submitted 21 or more requests in a given month (the top percentile), in part because conversations with city officials suggested that such heavy users were likely to be government employees, and were thus less representative of the general population in that they were already aware of the hidden work being conducted behind the scenes by the government. However, we note that all results are substantively similar when all observations are included $(N=21,986)$, and analyses conducted on the full sample are provided in the online appendix.

3.1.3. Dependent measures. We measured the effect of increased operational transparency on citizen engagement by assessing changes in residents' subsequent reporting behavior in response to the treatment, both in terms of the number of issues residents reported per month and the number of service categories in which residents reported (for example, categories included illegal graffiti, potholes, street lights, litter, etc. - a categorical breakdown of requests submitted through the Citizen's Connect application is provided in the online appendix). The city of Boston views increased reporting as a signal of much-desired civic engagement, suggesting that residents who use Citizen's Connect "serve as the eyes and ears for government, helping us find and respond to the basics of community quality of life" (City of Boston 2016). Namely, when residents become more engaged by reporting more service requests, it enables the city to allocate fewer workers to the diagnosis of public service issues, and more workers to their resolution.

3.1.4. Independent measures. Our focal independent measure, TRANSP $P_{i t}$, is an indicator variable, denoting whether resident $i$ had experienced at least one instance of operational transparency as of month $t$. In some specifications, we additionally include FIRST_TRANSP $P_{i t}$, which indicates whether month $t$ was the first time resident $i$ experienced transparency. This indicator is designed to separate the novelty effect of transparency from any persistent effects that it may have on engagement over the longer term. If, for example, the provision of operational transparency reframes the nature of the interaction for the resident, such that engaging is more meaningful, or the government is a more worthy engagement partner, we may expect to see the effects of transparency persist over the longer run. Consistently, in some specifications, which are presented in full in the online appendix, we incorporate a vector of indicator variables denoting the number of months since resident i's initial exposure to operational transparency, $1 M T H S \_S I N C E_{i t}, 2 M T H S \_S I N C E_{i t}, \ldots 14 M T H S \_S I N C E_{i t}$. Owing to the duration of our period of observation, the maximum number of months since a resident's initial exposure to transparency is 14 .

During the period of our Citizen's Connect study, the median service request was resolved within three days, but some requests remained unaddressed far longer. Of the 92,707 service requests submitted, 12,865 remained unaddressed at the end of the study, and $90 \%$ of those had been open for 25 days or more. Consequently, Citizen's Connect offered an ideal domain for comparing the effects of transparency among 
residents who experienced the government to be highly responsive (rapidly addressing their submitted requests) and residents who experienced the government to be less responsive (addressing requests slowly, if at all). Accordingly, in some specifications, we include CLOSED_PCT $T_{i t}$, which measures the timevarying percentage of service requests submitted by resident $i$ as of time $t$ that were not closed by the government. Incorporating this information allows us to explore whether government must be experienced by citizens as highly responsive in order for the gains from operational transparency to accrue.

3.1.5. Control measures. Although the City of Boston does not collect identifiable, user-level demographic data, we are able to observe several account-level characteristics that serve as useful control variables for our analysis. On a monthly basis, we control for the non-linear effect of each resident's tenure, $T_{E N U R E_{i t}}$ and TENURE ${ }_{i t}^{2}$, which accounts for the number of months resident $i$ has had the Citizen's Connect app as of month $t$, as well as CLOSED_CT $T_{i t}$, the total number of submissions resident $i$ has made that, as of month $t$, had been closed by the city. Finally, we incorporate resident and time fixed effects to account for time-invariant differences between residents, and resident-invariant differences across time that may have affected the propensity to submit service requests.

3.1.6. Empirical approach. To estimate the effects of operational transparency on resident engagement, both in terms of the number of monthly service requests submitted, and in terms of the number of categories in which residents submitted requests, we use the following fixed effects panel models with bootstrapped standard errors, clustered at the resident level. In our base specification, we model engagement as a function of transparency and a vector of control variables:

$$
\begin{aligned}
\text { ENGAGEMENT }_{i t}= & \alpha_{0}+\alpha_{1} \text { TRANSP }_{i t}+\alpha_{2} \text { TENURE }_{i t} \\
& +\alpha_{3} \text { TENURE }_{i t}^{2}+\alpha_{4} \text { CLOSED_CT }_{i t}+X_{i}+Z_{t}+\epsilon_{i t}
\end{aligned}
$$

To distinguish the novelty effects of transparency from its longer-run effects, we additionally include an indicator variable denoting the first month after which operational transparency was initially experienced:

$$
\begin{aligned}
\text { ENGAGEMENT }_{i t}= & \beta_{0}+\beta_{1} \text { TRANSP }_{i t}+\beta_{2} \text { FIRST_TRANSP }_{i t}+\beta_{3} \text { TENURE }_{i t} \\
& +\beta_{4} \text { TENURE }^{2}{ }_{i t}+\beta_{5} \text { CLOSED_CT } \\
i t & +X_{i}+Z_{t}+\epsilon_{i t}
\end{aligned}
$$

To test whether operational transparency has a persistent effect on engagement over time, we use the following specification:

$$
\begin{aligned}
& \text { ENGAGEMENT }_{i t}=\gamma_{0}+\left(\sum_{n=1}^{14} \gamma_{n} n M T H \operatorname{SSINCE} E_{i t}\right)+\gamma_{15} \text { TENURE }_{i t} \\
& +\gamma_{16} \text { TENURE }^{2}{ }_{i t}+\gamma_{17} \text { CLOSED_C } T_{i t}+X_{i}+Z_{t}+\epsilon_{i t}
\end{aligned}
$$


Finally, to isolate the contingent effects of government responsiveness, we interact the transparency variable with the non-linear effect of the percentage of each resident's past requests that were successfully closed by the government:

$$
\begin{aligned}
\text { ENGAGEMENT }_{i t}= & \delta_{0}+\delta_{1} \text { TRANSP }_{i t}+\delta_{2} C L O S E D \_P C T_{i t}+\delta_{3} \text { TRANSP }_{i t} \times C L O S E D \_P C T_{i t} \\
& +\delta_{4} \text { CLOSED_PCT }{ }_{i t}^{2}+\delta_{5} \text { TRANSP }_{i t} \times C L O S E D \_P C T^{2}{ }_{i t}+\delta_{6} \text { TENURE }_{i t} \\
& +\delta_{7} \text { TENURE }^{2}{ }_{i t}+\delta_{8} C L O S E D \_C T_{i t}+X_{i}+Z_{t}+\epsilon_{i t}
\end{aligned}
$$

3.1.7. Results. As shown in Columns (1) and (4) of Table 1, operational transparency increased citizen engagement, leading residents to submit more service requests $(\beta=0.81 ; p<0.001)$ and to submit them in more categories $(\beta=0.44 ; p<0.001)$ in months following exposure to operational transparency than in the preceding months. Moreover, Columns (2) and (5) demonstrate that although the increases in service requests $(\beta=1.63 ; p<0.001)$ and request categories $(\beta=1.11 ; p<0.001)$ were especially strong in the month immediately following residents' first experience with operational transparency, the effects persisted significantly eleven months after a resident's initial exposure, as documented in the online appendix. Overall, residents submitted an average of $59.8 \%$ more public service requests $(\beta=0.40 ; p<0.001)$ in $37.7 \%$ more categories $(\beta=0.17 ; p<0.001)$ following exposure to operational transparency.

Although we identify a positive main effect of operational transparency on an individual's subsequent willingness to engage with government, it's possible that these effects depend on the level of responsiveness that individual has experienced from the government during her interactions with it in the past. Columns (3) and (6) of Table 1 show that government responsiveness was associated with an increase in citizen engagement, such that residents whose requests were successfully resolved submitted more requests $(\beta=$ $1.60 ; p<0.001)$ and in more categories $(\beta=1.12 ; p<0.001)$, but the relationship was concave, such that resident engagement exhibited diminishing returns in responsiveness, $(\beta=-1.16 ; p<0.001)$ and $(\beta=-0.94$; $p<0.001$ ), respectively. We also observed a non-linear interaction between government responsiveness and transparency. Transparency was associated with the greatest increases in subsequent engagement among residents who experienced government being responsive to their requests, with such residents submitting more requests $(\beta=18.07 ; p<0.001)$ and in more categories $(\beta=8.54 ; p<0.001)$, but again the interaction was concave, such that the benefits of transparency were attenuated among people who experienced especially high levels of government responsiveness $(\beta=-10.76 ; p<0.001)$ and $(\beta=-5.11$; $p<0.001)$. 


\begin{tabular}{|c|c|c|c|c|c|c|}
\hline & $(1)$ & $(2)$ & $(3)$ & $(4)$ & (5) & $(6)$ \\
\hline & $\begin{array}{l}\text { Monthly } \\
\text { Count }\end{array}$ & $\begin{array}{l}\text { Monthly } \\
\text { Count }\end{array}$ & $\begin{array}{l}\text { Monthly } \\
\text { Count }\end{array}$ & $\begin{array}{l}\text { Category } \\
\text { Count }\end{array}$ & $\begin{array}{l}\text { Category } \\
\text { Count }\end{array}$ & $\begin{array}{l}\text { Category } \\
\text { Count }\end{array}$ \\
\hline Transparency & $\begin{array}{c}0.807^{* * *} \\
(0.063)\end{array}$ & $\begin{array}{c}0.404^{* * *} \\
(0.057)\end{array}$ & $\begin{array}{c}-6.980^{* * *} \\
(0.930)\end{array}$ & $\begin{array}{c}0.439^{\star * *} \\
(0.029)\end{array}$ & $\begin{array}{c}0.167^{* * *} \\
(0.031)\end{array}$ & $\begin{array}{c}-3.312^{* * *} \\
(0.579)\end{array}$ \\
\hline First transparency month indicator & & $\begin{array}{c}1.633^{* * *} \\
(0.072)\end{array}$ & $\begin{array}{c}1.660^{* * *} \\
(0.080)\end{array}$ & & $\begin{array}{c}1.105^{* * *} \\
(0.035)\end{array}$ & $\begin{array}{c}1.117^{* * *} \\
(0.034)\end{array}$ \\
\hline Percentage of requests closed & & & $\begin{array}{c}1.598^{* * *} \\
(0.109)\end{array}$ & & & $\begin{array}{c}1.121^{* * *} \\
(0.083)\end{array}$ \\
\hline Percentage of requests closed ${ }^{2}$ & & & $\begin{array}{c}-1.162^{* \star *} \\
(0.106)\end{array}$ & & & $\begin{array}{c}-0.940^{* * *} \\
(0.068)\end{array}$ \\
\hline Transparency x Percentage closed & & & $\begin{array}{c}18.067^{* * *} \\
(2.355)\end{array}$ & & & $\begin{array}{c}8.540^{* * *} \\
(1.465)\end{array}$ \\
\hline Transparency x Percentage closed ${ }^{2}$ & & & $\begin{array}{c}-10.764^{* * *} \\
(1.459)\end{array}$ & & & $\begin{array}{c}-5.105^{* * *} \\
(0.906)\end{array}$ \\
\hline Tenure & $\begin{array}{c}-0.022^{* * *} \\
(0.001)\end{array}$ & $\begin{array}{c}-0.021^{* * *} \\
(0.001)\end{array}$ & $\begin{array}{c}-0.022^{* * *} \\
(0.001)\end{array}$ & $\begin{array}{c}-0.018^{* * *} \\
(0.000)\end{array}$ & $\begin{array}{c}-0.017^{* * *} \\
(0.000)\end{array}$ & $\begin{array}{c}-0.018^{* * *} \\
(0.000)\end{array}$ \\
\hline Tenure $^{2}$ & $\begin{array}{c}0.000^{* * *} \\
(0.000)\end{array}$ & $\begin{array}{c}0.000^{* * *} \\
(0.000)\end{array}$ & $\begin{array}{c}0.000^{* * *} \\
(0.000)\end{array}$ & $\begin{array}{c}0.000^{* * *} \\
(0.000)\end{array}$ & $\begin{array}{c}0.000^{* * *} \\
(0.000)\end{array}$ & $\begin{array}{c}0.000^{* * *} \\
(0.000)\end{array}$ \\
\hline Total number of closed submissions & $\begin{array}{c}-0.069^{* * *} \\
(0.007)\end{array}$ & $\begin{array}{c}-0.062^{* * *} \\
(0.007)\end{array}$ & $\begin{array}{c}-0.064^{* * *} \\
(0.006)\end{array}$ & $\begin{array}{c}-0.029^{* * *} \\
(0.003)\end{array}$ & $\begin{array}{c}-0.024^{* * *} \\
(0.003)\end{array}$ & $\begin{array}{c}-0.026^{* * *} \\
(0.003)\end{array}$ \\
\hline Constant & $\begin{array}{c}0.707^{* * *} \\
(0.022)\end{array}$ & $\begin{array}{c}0.676^{* * *} \\
(0.022)\end{array}$ & $\begin{array}{c}0.271^{* * *} \\
(0.050)\end{array}$ & $\begin{array}{c}0.464^{* * *} \\
(0.012)\end{array}$ & $\begin{array}{c}0.443^{* * *} \\
(0.011)\end{array}$ & $\begin{array}{c}0.262^{* * *} \\
(0.026)\end{array}$ \\
\hline Observations & 371,992 & 371,992 & 371,992 & 371,992 & 371,992 & 371,992 \\
\hline R-squared & 0.070 & 0.089 & 0.092 & 0.059 & 0.088 & 0.091 \\
\hline Number of reporters & 21,786 & 21,786 & 21,786 & 21,786 & 21,786 & 21,786 \\
\hline
\end{tabular}

Table 1: Operational transparency increases resident engagement $(\mathrm{N}=371,992$ monthly observations from 21,786 resident reporters, withholding high-intensity submitters) (Study 1). Residents submit more service requests, and across a broader array of categories after being exposed to operational transparency. *, **, and $* * *$ signify significance at the $10 \%, 5 \%$ and $1 \%$ levels, respectively, relative to the baseline condition.

Although residents who experienced the government to be perfectly responsive to their requests exhibited significant gains in engagement after exposure to transparency, the gains from transparency were strongest among residents who experienced their government to be responsive, but not perfect. On the other hand, under relatively low levels of responsiveness, relative to the baseline, transparency was associated with reduced levels of citizen engagement $(\beta=-6.98 ; p<0.001)$ and $(\beta=-3.31 ; p<0.001)$, respectively. (Note that due to the manner in which transparency was operationalized in our analysis, all residents who experienced transparency had at least one request successfully resolved.) We present these results graphically in Figure 3. The figure demonstrates a consistent pattern wherein operational transparency increases engagement among residents who had experienced the government to be at least moderately responsive in the past. 

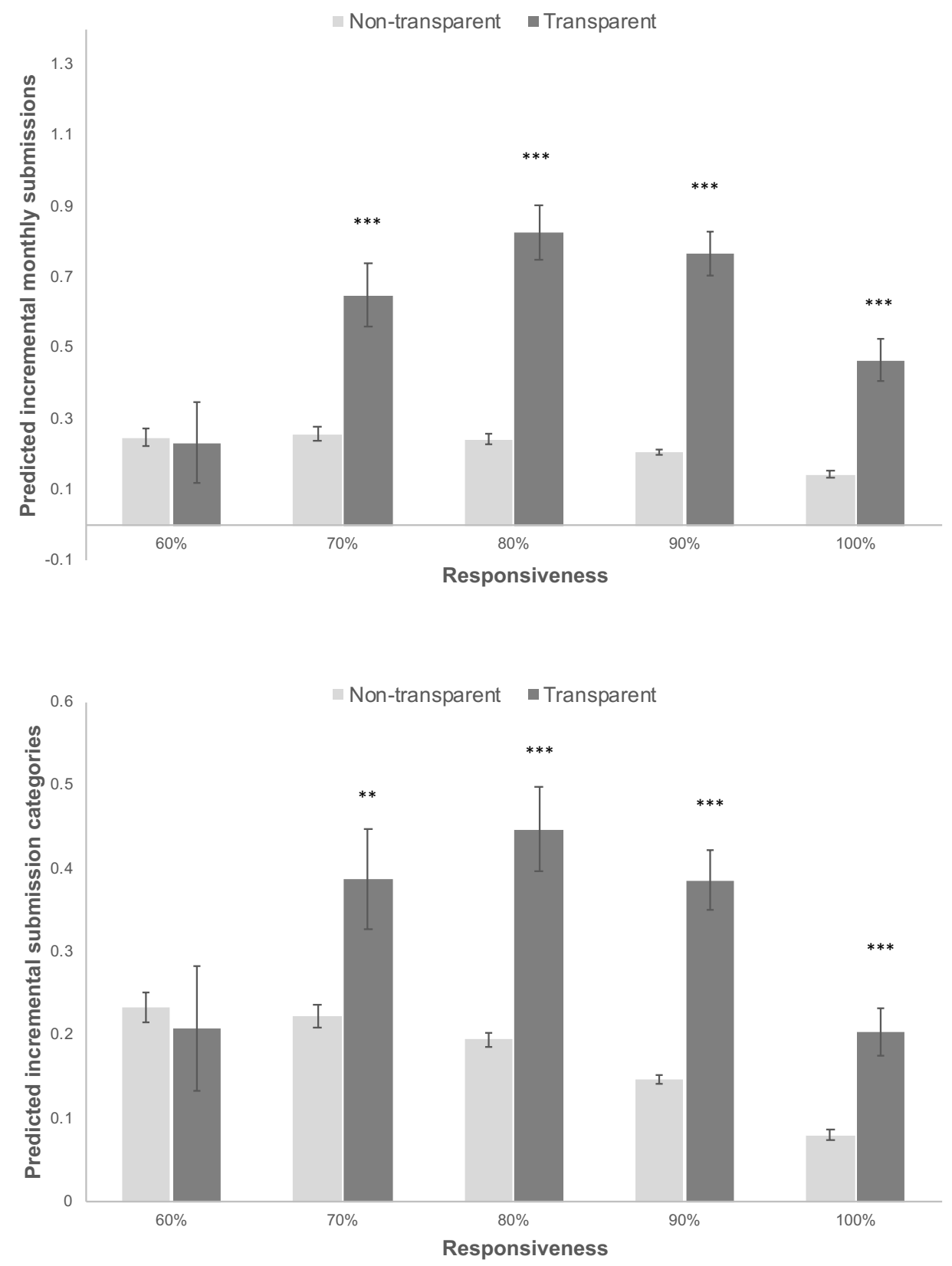

Figure 3: Operational transparency increased the predicted incremental monthly submissions and count of submission categories among residents who, in the past, had experienced at least a moderate level of responsiveness from the government (Study 1). All models are estimated with bootstrapped standard errors. $*, * *$, and $* * *$ signify significance at the $10 \%, 5 \%$ and $1 \%$ levels, respectively, relative to the baseline nontransparent condition. Error bars represent Delta-method standard errors.

3.1.8 Robustness test. As described above, the as-if random nature of the assignment of photos in this field data is important in interpreting our results, since if, for example, city workers chose to post photos only for requests that were resolved most satisfactorily, it may have been the elevated quality of responses that included a photo, and not the provision of operational transparency itself, that led to increased resident 
engagement. To test the robustness of our results to this possibility, we exploit a feature of the data that allows us to break this potential endogeneity. Specifically, observing operational transparency through Citizen's Connect required that the resident had a request closed by a Public Works team that posted a photo, and that the resident had a version of the app that supported their seeing that photo. Although the new version of Citizen's Connect diffused rapidly, for $18.05 \%$ of the resident-month observations corresponding with first-time service requests that were resolved with a photo, the resident did not (as of the time they submitted the request) have a version of the app that supported transparency.

\begin{tabular}{|c|c|c|c|c|c|c|}
\hline & (1) & (2) & (3) & (4) & (5) & (6) \\
\hline & $\begin{array}{c}\text { Monthly } \\
\text { Count }\end{array}$ & $\begin{array}{c}\text { Monthly } \\
\text { Count }\end{array}$ & $\begin{array}{c}\text { Monthly } \\
\text { Count }\end{array}$ & $\begin{array}{c}\text { Category } \\
\text { Count }\end{array}$ & $\begin{array}{c}\text { Category } \\
\text { Count }\end{array}$ & $\begin{array}{c}\text { Category } \\
\text { Count }\end{array}$ \\
\hline Transparency & $\begin{array}{c}0.489^{* * *} \\
(0.104)\end{array}$ & $\begin{array}{c}0.153 \\
(0.108)\end{array}$ & $\begin{array}{c}-7.456^{\star \star *} \\
(1.168)\end{array}$ & $\begin{array}{c}0.394^{\star * *} \\
(0.068)\end{array}$ & $\begin{array}{l}0.164^{* *} \\
(0.074)\end{array}$ & $\begin{array}{c}-3.352^{\star \star *} \\
(0.756)\end{array}$ \\
\hline Photo posted indicator & $\begin{array}{l}0.227^{\star *} \\
(0.104)\end{array}$ & $\begin{array}{c}0.162 \\
(0.101)\end{array}$ & $\begin{array}{l}0.168^{*} \\
(0.095)\end{array}$ & $\begin{array}{l}-0.008 \\
(0.064)\end{array}$ & $\begin{array}{l}-0.052 \\
(0.068)\end{array}$ & $\begin{array}{l}-0.053 \\
(0.052)\end{array}$ \\
\hline Updated app indicator & $\begin{array}{c}0.436^{\star \star \star} \\
(0.028)\end{array}$ & $\begin{array}{c}0.424^{\star \star *} \\
(0.029)\end{array}$ & $\begin{array}{c}0.404^{\star \star \star} \\
(0.038)\end{array}$ & $\begin{array}{c}0.196^{\star \star \star} \\
(0.018)\end{array}$ & $\begin{array}{c}0.188^{\star \star *} \\
(0.015)\end{array}$ & $\begin{array}{c}0.167^{\star \star *} \\
(0.014)\end{array}$ \\
\hline First transparency month indicator & & $\begin{array}{c}1.612^{\star \star \star} \\
(0.073)\end{array}$ & $\begin{array}{c}1.642^{\star \star \star} \\
(0.062)\end{array}$ & & $\begin{array}{c}1.100^{\star \star \star} \\
(0.033)\end{array}$ & $\begin{array}{c}1.114^{\star \star *} \\
(0.031)\end{array}$ \\
\hline Percentage of requests closed & & & $\begin{array}{c}1.048^{* * *} \\
(0.146)\end{array}$ & & & $\begin{array}{c}0.906^{* \star *} \\
(0.083)\end{array}$ \\
\hline Percentage of requests closed ${ }^{2}$ & & & $\begin{array}{c}-0.713^{* \star *} \\
(0.140)\end{array}$ & & & $\begin{array}{c}-0.764^{* \star *} \\
(0.084)\end{array}$ \\
\hline Transparency x Percentage closed & & & $\begin{array}{c}18.815^{\star * *} \\
(3.027)\end{array}$ & & & $\begin{array}{c}8.727^{\star \star *} \\
(1.900)\end{array}$ \\
\hline Transparency $\times$ Percentage closed ${ }^{2}$ & & & $\begin{array}{c}-11.301^{* * *} \\
(1.887)\end{array}$ & & & $\begin{array}{c}-5.253^{* * *} \\
(1.160)\end{array}$ \\
\hline Tenure & $\begin{array}{c}-0.025^{\star \star * *} \\
(0.001)\end{array}$ & $\begin{array}{c}-0.024^{* * *} \\
(0.001)\end{array}$ & $\begin{array}{c}-0.024^{* * *} \\
(0.001)\end{array}$ & $\begin{array}{c}-0.019^{* * *} \\
(0.000)\end{array}$ & $\begin{array}{c}-0.019^{* \star *} \\
(0.000)\end{array}$ & $\begin{array}{c}-0.019^{\text {*** }} \\
(0.000)\end{array}$ \\
\hline Tenure $^{2}$ & $\begin{array}{c}0.000^{* * *} \\
(0.000)\end{array}$ & $\begin{array}{c}0.000^{* * *} \\
(0.000)\end{array}$ & $\begin{array}{c}0.000^{* * *} \\
(0.000)\end{array}$ & $\begin{array}{c}0.000^{\star \star *} \\
(0.000)\end{array}$ & $\begin{array}{c}0.000^{\star * *} \\
(0.000)\end{array}$ & $\begin{array}{c}0.000^{* * *} \\
(0.000)\end{array}$ \\
\hline Total number of closed submissions & $\begin{array}{c}-0.077^{\star * *} \\
(0.007)\end{array}$ & $\begin{array}{c}-0.070^{* * *} \\
(0.006)\end{array}$ & $\begin{array}{c}-0.072^{* \star *} \\
(0.008)\end{array}$ & $\begin{array}{c}-0.032^{\star * *} \\
(0.003)\end{array}$ & $\begin{array}{c}-0.028^{* * *} \\
(0.003)\end{array}$ & $\begin{array}{c}-0.028^{* * *} \\
(0.003)\end{array}$ \\
\hline Constant & $\begin{array}{c}0.689^{\star * *} \\
(0.020)\end{array}$ & $\begin{array}{c}0.659^{* \star *} \\
(0.020)\end{array}$ & $\begin{array}{c}0.356^{* * *} \\
(0.053)\end{array}$ & $\begin{array}{c}0.455^{\star * *} \\
(0.009)\end{array}$ & $\begin{array}{c}0.435^{* * *} \\
(0.010)\end{array}$ & $\begin{array}{c}0.293^{* * *} \\
(0.028)\end{array}$ \\
\hline Observations & 371,992 & 371,992 & 371,992 & 371,992 & 371,992 & 371,992 \\
\hline R-squared & 0.076 & 0.095 & 0.098 & 0.063 & 0.091 & 0.094 \\
\hline Number of reporters & 21,786 & 21,786 & 21,786 & 21,786 & 21,786 & 21,786 \\
\hline
\end{tabular}

Table 2: Operational transparency increases resident engagement after separately controlling for whether a request was resolved with a photo and the user's app version $(\mathrm{N}=371,992$ monthly observations from 21,786 resident reporters, withholding high-intensity submitters) (Study 1). Residents submit more service requests, and across a broader array of categories after being exposed to operational transparency. *, **, and $* * *$ signify significance at the $10 \%, 5 \%$ and $1 \%$ levels, respectively, relative to the baseline condition.

By including separate indicator variables into our specifications above that control for whether the resident had ever made a request that was closed with a photo, whether the resident had a version of the app that supports observing transparency, and whether the resident had ever made a request with a version of the app that supports transparency that was closed with a photo, we are able to make the provision of 
operational transparency exogenous to both the resident and the worker. By doing so, we can separately analyze whether the effects we observe arise from selection effects or from the provision of operational transparency itself. This analysis requires two caveats - both of which bias against finding support for operational transparency. First, we cannot directly observe from our data when a user updated their app we can only observe which version of the app they had when they submitted each service request. As such, even if a resident didn't have a version of the app that supported transparency when they submitted a request that was ultimately closed with a photo, it doesn't mean that they didn't experience transparency after receiving an updated version of the app. Indeed, updates to the app diffused rapidly (Figure 1), and under this specification, any effects attributable to observing operational transparency after receiving the update would be credited to the indicator variable for whether the worker posted a photo, and not to the treatment variable itself - thus biasing against observing an effect. Second, identification to carry out this analysis comes from a narrower subset of the observations, which diminishes its statistical power. Nevertheless, as shown in Table 2, the effects documented above are generally robust when these controls are included, reinforcing the primary conclusions that operational transparency promoted increased engagement among residents, especially among those for whom the government had been at least moderately responsive.

\subsection{Study 2: Operational transparency, responsiveness, and citizen attitudes}

Study 2 extends our analysis of the impact of operational transparency and government responsiveness on citizen engagement by exploring its effects on citizens' attitudes about government - in particular, their level of trust in government and their support for government programs.

3.2.1. Participants. 125 Boston-area residents of voting age $\left(47.2 \%\right.$ female, $\left.M_{\text {age }}=23.1\right)$ were recruited to take part in this and a series of unrelated studies at a behavioral research lab affiliated with a major university near the City of Boston in exchange for $\$ 15.00$.

3.2.2. Design and procedure. We partnered with Code for America, a non-partisan, non-political 501(c)(3) organization that works with residents and local governments throughout the United States to leverage digital technology to solve community problems (Code for America 2019). The organization brings together technology and design professionals to work with city governments to build open source applications that promote civic engagement and participation. One such open source application is "The Daily Brief," a website Code for America deployed in multiple cities, including Boston, which provided operational transparency into the service requests residents were submitting and the efforts of the government to resolve them.

To deliver operational transparency, service requests that had been submitted to the city through the Citizen's Connect app described in Study 1, as well as through other reporting channels, were retrieved on 
a daily basis from the city's databases and displayed graphically on The Daily Brief website. Each service request was represented by a pushpin, overlaid on a map of the city, indicating its location. By clicking on each pin, website visitors could see the title, photo, address, and description of the corresponding issue, along with a timestamp indicating when the service request was submitted to the city, and the period of time that had elapsed since its submission. Pushpins were color-coded based on the status of each request. Requests that were "opened yesterday," were represented with orange pins, requests that were "closed yesterday," were represented with blue pins, and the remaining "open" requests were represented with red pins. In addition, a tally summarizing the total number of requests in each category was displayed at the bottom of the screen.

As described in Study 1, during the period of our research, there was considerable variation in the City of Boston's capacity to address public service requests in a timely manner - although the median service request was resolved within three days, a backlog of requests remained unaddressed for far longer. Consequently, by manipulating which service requests The Daily Brief displayed (e.g., accentuating requests submitted and/or resolved yesterday, vs. accentuating all open requests), our experiment could leverage operational transparency and real performance data to portray the Boston government to be more or less responsive - facilitating our investigation of how transparency and responsiveness affect resident attitudes. Participants were randomly-assigned to experience one of three versions of The Daily Brief website that had been developed specifically for this experiment. Those in the non-transparent condition saw a version of the website without any pushpins, merely viewing the tally of service requests in each category. Remaining participants were assigned to one of two transparency conditions. Participants in the transparent/responsive condition saw the same website as participants in the non-transparent condition, but with the addition of pins representing requests that had been opened and closed the previous day. Finally, participants in the transparent/non-responsive condition saw the same website as participants in the transparent/responsive condition, but with the inclusion of pins visualizing the substantial backlog of open service requests that had not yet been resolved (Figure 4).

3.2.3 Manipulation check. It is important to note that a limitation of this experimental design is that we manipulate responsiveness between our two transparency conditions by toggling the categories of requests shown to participants (e.g. opened yesterday, closed yesterday, and all open requests). An ideal manipulation would not have conflated "responsiveness" and "categories of transparency provided" by holding the categories shown constant and randomly-assigning participants to experience different levels of government responsiveness. As this study provided real Boston-area residents with transparency into the Boston government's actual performance, this ideal manipulation was not a practical option without using deception. Consequently, in a post-hoc analysis, we recruited a separate sample of 120 participants (48.76\% 
female, $M_{\text {age }}=35.73$ ), randomly assigning them to observe a screenshot of the Daily Brief website in one of the two transparency conditions. We provided each participant the same description of the Daily Brief website, and asked each to evaluate how transparent and how responsive they perceived the Boston local government to be in resolving residents' service requests. 101 participants passed an attention check question at the end of the study asking them to recall the colors of the pins they observed on the map (49.50\% female, $M_{\text {age }}=36.62$ ).

However, our results are similar if all observations are included. Although we observe no significant differences in transparency perceptions between the transparent/responsive $(M=5.57 S D=1.41)$ and transparent/non-responsive conditions $(M=5.46 S D=1.33, T(99)=0.41 p=0.68)$, we do observe a significant difference in perceived responsiveness. Participants in the transparent/responsive condition $(M=4.21$ $S D=1.73$ ) perceived the Boston government to be more responsive than participants in the transparent/nonresponsive condition $(M=3.30 S D=1.91, T(99)=2.51, p<0.05)$. This pattern of results suggests that the experimental manipulation utilized, albeit imperfect, was likely experienced by the Boston residents we studied as intended. Moreover, we note that Study 3 utilizes a hypothetical experimental scenario, and as a consequence replicates the present analysis with a cleaner manipulation.

3.2.4 Survey measures. To measure participants' trust in and support for government, we relied upon the Pew Center for the People and the Press Trust in Government Survey (Dimock et al. 2013). This 14question battery, the full text of which appears in the online appendix, measures participants' attitudes about government's role in their everyday lives, government's role as being positive or negative, the quality of civil service, and whether they trust government to do what is right, as well as whether they would prefer a bigger or smaller government with more or fewer services, and whether government programs should be maintained or cut back. Responses were standardized and an exploratory factor analysis was conducted, which revealed nine questions that measured participants' trust in government $(\alpha=0.83)$, and two questions that measured support for government programs $(\alpha=0.74)$. The full text of all questions and the factor analysis is provided in the online appendix.

3.2.4. Control measures. Given that responses on these survey measures are likely correlated with individuals' political ideology, we assessed participants' political orientation, which we use as a control variable in our analyses. We also control for gender, age, income, whether the participant is a member of a racial minority, and level of education. Finally, we control for the number of active service issues present on the site at the time of the participant's interaction with it, as well as the amount of time each participant spent browsing the Daily Brief website. 


\section{A. Non-transparent}

Participants only observed counts of the number of open, opened yesterday, and closed yesterday requests.
B. Transparent/ responsive

In addition to the information presented in (A) above, participants additionally observed orange pins representing requests opened the previous day, and blue pins representing requests closed the previous day.

\section{Transparent/ non-responsive} In addition to the information presented in (B) above, participants additionally observed red pins representing the large backlog of open and unresolved requests.
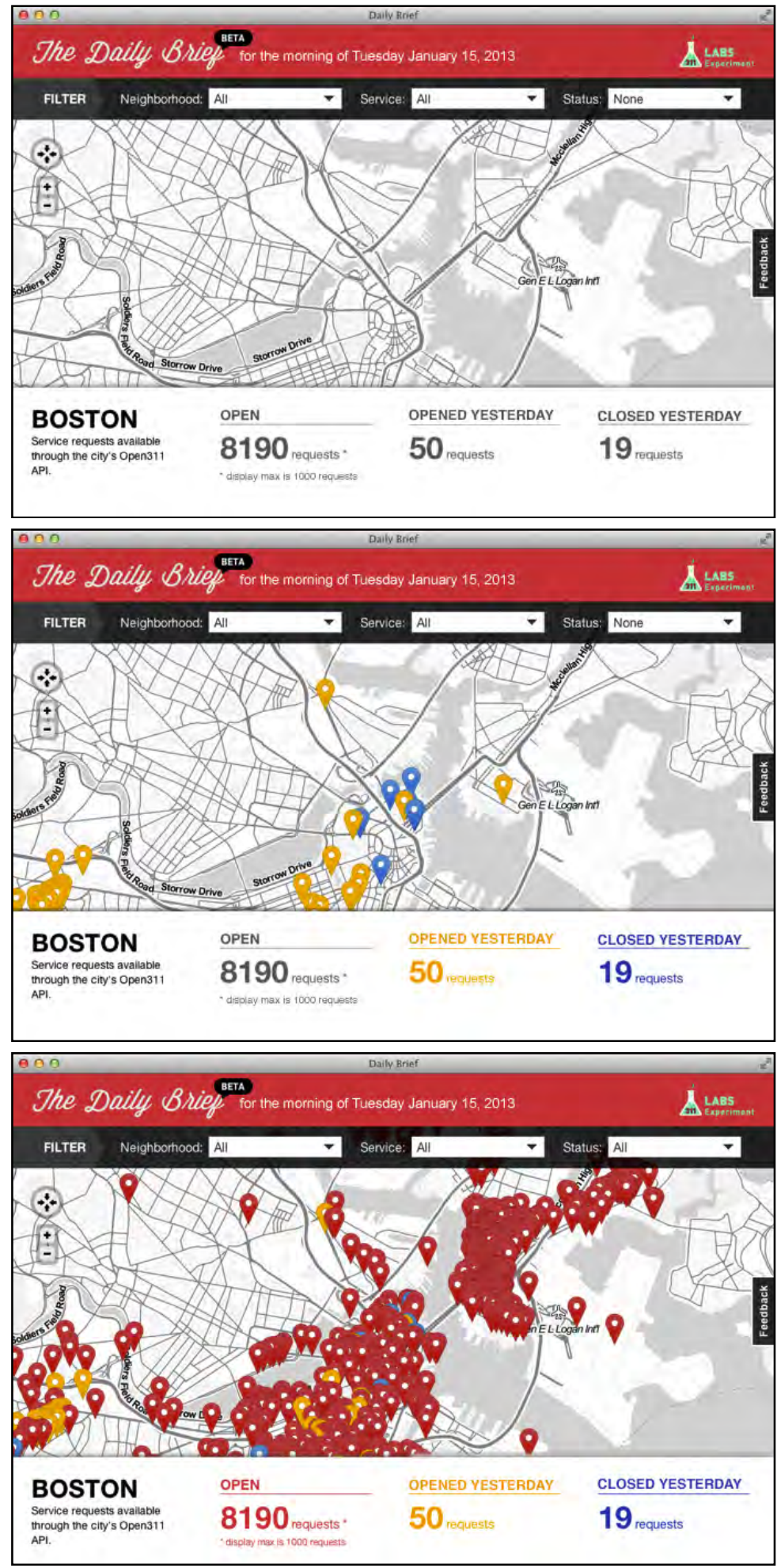

Figure 4: Screenshots from the Daily Brief, illustrating the a) non-transparent, b) transparent/responsive, and c) transparent/non-responsive conditions (Study 2). 


\begin{tabular}{|c|c|c|c|c|c|}
\hline & (1) & $(2)$ & (3) & (4) & (5) \\
\hline & $\begin{array}{c}\text { Composite } \\
\text { Trust }\end{array}$ & $\begin{array}{c}\text { Composite } \\
\text { Trust }\end{array}$ & $\begin{array}{l}\text { Composite } \\
\text { Support }\end{array}$ & $\begin{array}{c}\text { Composite } \\
\text { Support }\end{array}$ & $\begin{array}{l}\text { Composite } \\
\text { Support }\end{array}$ \\
\hline Transparent/ responsive & $\begin{array}{l}0.288^{* *} \\
(0.142)\end{array}$ & $\begin{array}{l}0.325^{\star *} \\
(0.137)\end{array}$ & $\begin{array}{l}0.375^{*} \\
(0.190)\end{array}$ & $\begin{array}{l}0.358^{* *} \\
(0.173)\end{array}$ & $\begin{array}{c}0.256 \\
(0.168)\end{array}$ \\
\hline Transparent/ non-responsive & $\begin{array}{c}0.055 \\
(0.139)\end{array}$ & $\begin{array}{c}0.068 \\
(0.149)\end{array}$ & $\begin{array}{c}0.197 \\
(0.206)\end{array}$ & $\begin{array}{c}0.210 \\
(0.163)\end{array}$ & $\begin{array}{c}0.188 \\
(0.153)\end{array}$ \\
\hline Composite trust & & & & & $\begin{array}{c}0.315^{\star \star \star} \\
(0.109)\end{array}$ \\
\hline Female & & $\begin{array}{c}0.096 \\
(0.121)\end{array}$ & & $\begin{array}{c}0.007 \\
(0.141)\end{array}$ & $\begin{array}{l}-0.023 \\
(0.139)\end{array}$ \\
\hline Age & & $\begin{array}{l}-0.020 \\
(0.012)\end{array}$ & & $\begin{array}{l}0.029^{* *} \\
(0.014)\end{array}$ & $\begin{array}{l}0.035^{* *} \\
(0.014)\end{array}$ \\
\hline Minority & & $\begin{array}{l}-0.089 \\
(0.117)\end{array}$ & & $\begin{array}{l}-0.071 \\
(0.133)\end{array}$ & $\begin{array}{l}-0.043 \\
(0.129)\end{array}$ \\
\hline Income & & $\begin{array}{l}-0.005 \\
(0.022)\end{array}$ & & $\begin{array}{c}-0.075^{* * *} \\
(0.027)\end{array}$ & $\begin{array}{c}-0.074^{\star \star \star} \\
(0.027)\end{array}$ \\
\hline Missing Income & & $\begin{array}{c}0.083 \\
(0.189)\end{array}$ & & $\begin{array}{l}0.444^{*} \\
(0.252)\end{array}$ & $\begin{array}{l}0.417^{*} \\
(0.249)\end{array}$ \\
\hline Political orientation & & $\begin{array}{l}-0.009 \\
(0.054)\end{array}$ & & $\begin{array}{c}-0.357^{\star * *} \\
(0.055)\end{array}$ & $\begin{array}{c}-0.354^{* * *} \\
(0.054)\end{array}$ \\
\hline Not political & & $\begin{array}{c}0.368 \\
(0.284)\end{array}$ & & $\begin{array}{l}-0.946^{*} \\
(0.483)\end{array}$ & $\begin{array}{l}-1.062^{*} \\
(0.546)\end{array}$ \\
\hline Active & & $\begin{array}{l}-0.005 \\
(0.008)\end{array}$ & & $\begin{array}{l}-0.002 \\
(0.008)\end{array}$ & $\begin{array}{l}-0.001 \\
(0.008)\end{array}$ \\
\hline Time on site & & $\begin{array}{l}-0.003^{* *} \\
(0.001)\end{array}$ & & $\begin{array}{c}-0.004^{\star * *} \\
(0.001)\end{array}$ & $\begin{array}{c}-0.003^{\star * *} \\
(0.001)\end{array}$ \\
\hline Constant & $\begin{array}{l}-0.120 \\
(0.099)\end{array}$ & $\begin{array}{c}41.828 \\
(58.187)\end{array}$ & $\begin{array}{l}-0.200 \\
(0.147)\end{array}$ & $\begin{array}{c}17.691 \\
(60.326)\end{array}$ & $\begin{array}{c}4.518 \\
(57.718)\end{array}$ \\
\hline $\begin{array}{l}\text { Observations } \\
\text { R-squared }\end{array}$ & $\begin{array}{c}125 \\
0.037\end{array}$ & $\begin{array}{c}125 \\
0.109\end{array}$ & $\begin{array}{c}125 \\
0.029\end{array}$ & $\begin{array}{c}125 \\
0.398\end{array}$ & $\begin{array}{c}125 \\
0.445\end{array}$ \\
\hline
\end{tabular}

Table 3: Operational transparency increases trust in government and support for government programs (Study 2). Trust and support are highest in the transparent and responsive condition, when residents can see active service requests that were recently opened and closed. $*, * *$, and $* * *$ signify significance at the $10 \%$, $5 \%$ and $1 \%$ levels, respectively, relative to the baseline non-transparent condition. Adding the backlog of unfulfilled service requests does not enhance or diminish trust or support for government.

3.2.2. Results. As shown in Table 3, entering the transparency conditions into regressions modeling our composite measures for trust and support for government programs revealed that participants randomlyassigned to experience transparency that showed the government to be responsive to citizen's concerns by visualizing both recently opened and closed service requests - reported higher levels of trust in government $(\beta=0.33, p<0.05)$ and increased support for government programs $(\beta=0.36, p<0.05)$ relative to participants in the non-transparent control. This pattern of results, in which participants observing transparency into the responsive work that government was doing perceived the government more favorably than participants who did not observe the work, persisted on average across individual items as well. Participants in the transparent/ non-responsive condition, who in addition to visualizing recently opened and closed requests also saw the large backlog of requests the government had not resolved, did not report 
the same elevated levels of trust in and support for government, relative to the non-transparent control. In particular, participants in the transparent/ non-responsive condition were no more trusting of government $(\beta=0.07, p=\mathrm{NS})$ nor more supportive of government programs $(\beta=0.21, p=\mathrm{NS})$ than participants who observed the non-transparent condition.

To what extent did trust in government brought about by increased operational transparency lead to greater support for government programs? To answer this question, we conducted a causal mediation analysis (Hicks and Tingley 2011, Imai et al. 2010). We found that the average causal mediation effect the change in support for government programs that was due to the transparency-induced change in trust was 0.102 (confidence interval: $0.013,0.233$ ). This effect accounted for $28.1 \%$ of the total effect of the transparent/responsive condition on support for government programs. Taken together, these results suggest that surfacing the work that government is doing, may not only increase levels of citizen engagement as documented in Study 1, but also increase levels of citizen trust and in turn, support for government. Moreover, consistent with the prior results, we find that operational transparency's capacity to improve attitudes toward government is limited to cases when it reveals a responsive government actively resolving resident requests. Interestingly however, even when transparency portrays the government to be less responsive, by exposing the growing backlog of unresolved service requests, we do not find evidence that transparency decreases trust and support below the baseline non-transparent condition. In the next study, we delve into the mechanisms underlying the effects of operational transparency and responsiveness on resident attitudes and engagement.

\subsection{Study 3: Underlying mechanisms driving the effects of operational transparency}

3.3.1. Participants. 1,497 participants $\left(46.9 \%\right.$ female, $\left.M_{\mathrm{age}}=37.72\right)$ were recruited on the Amazon Mechanical Turk platform to participate in a five-minute research study on perceptions of local government in exchange for $\$ 1.00$. We intended to recruit 1,500 participants, in order to reach a minimum of 200 participants in each of the study's six experimental conditions after excluding those who failed the attention check. 127 participants failed to correctly answer the attention check question, resulting in a final sample of 1,370 participants ( $48.3 \%$ female, $\left.M_{\mathrm{age}}=38.18\right)$.

3.3.2. Design and procedure. Upon completing the informed consent process, participants read a description of the Citizen's Connect app, and were provided a demonstration of how in Boston, residents can use the app to report public service requests, which the local government then works to resolve. Participants were asked to imagine that they were a resident of Boston, that they had used the app regularly in the past, and that they had found that the government had responded to their requests $[100 \%, 80 \%, 60 \%]$ of the time. Varying past responsiveness in this way facilitates an examination of the drivers of the pattern 
of results observed in the first two studies, wherein transparency led to increased attitudes and engagement when past responsiveness had been at least moderately high, but not when past responsiveness had been low. One potential explanation arises from the field of political science, wherein civic engagement has been shown to be shaped, in part, by feelings of efficacy - engagement may be driven in part by the agency an individual feels to produce a desired or intended result (Finkel 1985, Fox and Lawless 2010). However, the idea that past experiences influence attitudes about whether one's engagement will be worthwhile spans a wide variety of service contexts outside government. For example, feelings of efficacy have been shown to be an important driver of engagement in a variety of co-productive settings, such as in promoting student engagement in the classroom (Linnenbrink and Pintrich 2003), fostering engagement with self-service technologies in financial services (van Beuningen et al. 2008), increasing adherence to diets, exercise, and medical prescriptions in healthcare (Brus et al. 1999, Robertson and Keller 1992, Zrinyi et al. 2003). As such, we adapted three items from ANES (2019) intended to assess each participant's degree of internal efficacy ("Sometimes operations in the Boston local government seem so complicated that a person like me really can't understand what's going on.") and external efficacy ("Officials in the Boston local government don't care much what people like me think," and "People like me don't have any say in what gets done by the Boston local government."). Participants indicated the extent to which they agreed with each statement on a 7-item Likert scale, and we reverse-coded their responses to create an index of efficacy for each participant $(\alpha=0.871)$.

After manipulating past responsiveness and measuring the resulting degree of efficacy, participants were next asked to imagine that they had seen trash on the sidewalk, and that they had used the Citizen's Connect app to report it to the Boston local government. Then, on the following screen, participants were informed that the next day they saw a response posted in the app. Participants were randomly-assigned to receive either a non-transparent or operationally transparent response (Figure 5). Consistent with the manipulation in the field data in Study 1, participants randomly-assigned to the non-transparent condition saw their submission photo, as well as a tag indicating that the case had been closed, and text noting that the debris had been picked up. Participants randomly-assigned to the operationally transparent condition saw the same closed tag and text description, but additionally saw a photo of the same sidewalk cleared of debris. Hence the study was a 3(responsiveness: low, medium, high) x 2(transparency: non-transparent, transparent) design.

3.3.3. Survey measures. After experiencing the experimental manipulations, all participants were asked a battery of questions intended to trace out and test two potential causal paths between transparency and engagement that builds on prior research investigating the links among operational transparency and behaviors among customers and employees (Buell et al. 2017, Buell and Norton 2011, Grant 2007). In 
particular, we hypothesized that a consumer's willingness to engage with government would be influenced by transparency's capacity to improve their perceptions of the government itself (the institution with which they were being asked to engage), as well as its capacity to increase their perceptions that their engagement with government was impactful and worthwhile. For all questions, participants were asked to provide their perceptions on a 1-7 Likert scale.

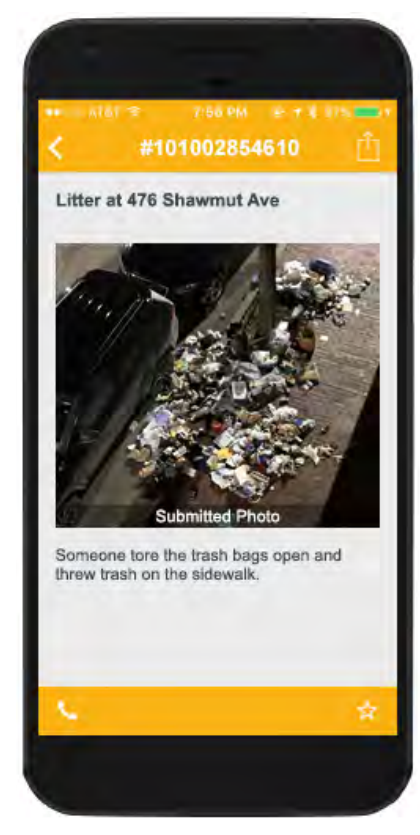

A. Submission

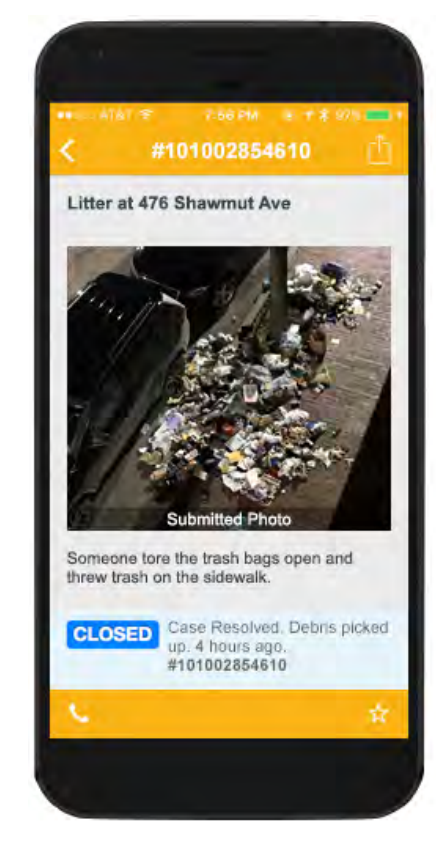

B. Non-transparent response

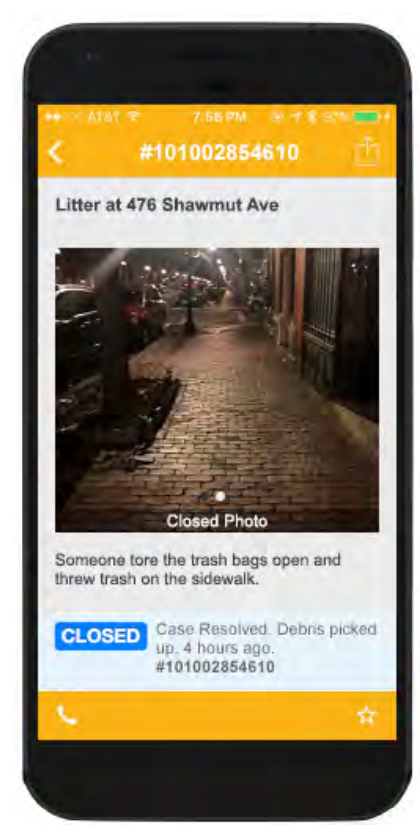

C. Transparent response

Figure 5: Screenshots from Study 3, demonstrating a) the submission, and the response in the b) nontransparent, and c) transparent conditions (Study 3).

First, following prior work on operational transparency's capacity to influence customer attitudes (Buell and Norton 2011, Buell et al. 2017), we measured perceived effort and feelings of appreciation toward the government. Just as perceived effort and appreciation had been shown to increase consumers' perceived value of a service, we hypothesized they may also lead to increased trust and support, as observed in Study 2, which could in turn serve as a driver of engagement. To that end, perceived effort was measured using four items: "How much effort do you think the Boston local government exerts on behalf of its citizens?", "How much expertise do you think the Boston local government has?", "How much experience does the Boston local government have?", and "How thorough is the Boston local government in addressing the needs of its citizens?" Leveraging the same prior research, appreciation was measured using the following three items: "How positive do you feel toward the Boston local government?", "How grateful do you feel toward the Boston local government?", and "How appreciative do you feel toward the Boston local government?" Building on prior research investigating the links among transparency and trust (Mohan et 
al. 2019), we measured trust with the following three items: "I can trust the Boston local government.", "I can rely on the Boston local government.", and "The Boston local government is honest." Support was measured using two items: "Which would you rather have: Smaller Boston local government with fewer services, or bigger Boston local government with more services?", and "Where on the following scale would you place yourself: Boston local government programs should be cut back to Boston local government programs should be expanded?" Responses were aggregated to create composite scales for perceived effort $(\alpha=0.913)$, appreciation $(\alpha=0.946)$, trust $(\alpha=0.930)$, and support $(\alpha=0.830)$.

\begin{tabular}{lccccc}
\hline & $\begin{array}{c}(1) \\
\text { Engage }\end{array}$ & $\begin{array}{c}(2) \\
\text { Engage }\end{array}$ & $\begin{array}{c}(3) \\
\text { Engage }\end{array}$ & $\begin{array}{c}(4) \\
\text { Engage }\end{array}$ & $\begin{array}{c}(5) \\
\text { Engage }\end{array}$ \\
\hline Transparency indicator & $0.129^{* *}$ & -0.000 & $0.205^{* *}$ & $0.197^{*}$ & $0.201^{* * *}$ \\
& $(0.059)$ & $(0.102)$ & $(0.104)$ & $(0.100)$ & $(0.073)$ \\
Female indicator & $0.331^{* * *}$ & $0.251^{* *}$ & $0.320^{* * *}$ & $0.377^{* * *}$ & $0.355^{* * *}$ \\
Age & $(0.059)$ & $(0.099)$ & $(0.109)$ & $(0.100)$ & $(0.075)$ \\
& $0.007^{* * *}$ & $0.009^{* *}$ & $0.013^{* *}$ & $0.013^{* *}$ & $0.006^{* *}$ \\
Age ${ }^{2}$ & $(0.002)$ & $(0.004)$ & $(0.006)$ & $(0.005)$ & $(0.003)$ \\
Education level & 0.000 & -0.000 & $-0.000^{*}$ & $0.000^{* * *}$ & $0.000^{* * *}$ \\
& $(0.000)$ & $(0.000)$ & $(0.000)$ & $(0.000)$ & $(0.000)$ \\
Income level & -0.003 & -0.035 & 0.005 & 0.027 & 0.015 \\
& $(0.025)$ & $(0.039)$ & $(0.042)$ & $(0.054)$ & $(0.033)$ \\
Political knowledge & $0.049^{* * *}$ & $0.057^{* *}$ & 0.049 & $0.047^{*}$ & $0.047^{* *}$ \\
& $(0.016)$ & $(0.024)$ & $(0.030)$ & $(0.028)$ & $(0.021)$ \\
Political interest & 0.007 & 0.005 & -0.017 & 0.037 & 0.010 \\
& $(0.062)$ & $(0.082)$ & $(0.098)$ & $(0.139)$ & $(0.085)$ \\
Political ideology & $0.089^{*}$ & $0.164^{* *}$ & 0.051 & 0.022 & 0.051 \\
& $(0.053)$ & $(0.077)$ & $(0.067)$ & $(0.131)$ & $(0.071)$ \\
Constant & -0.042 & 0.024 & -0.096 & -0.049 & -0.071 \\
& $(0.038)$ & $(0.057)$ & $(0.079)$ & $(0.062)$ & $(0.049)$ \\
& $5.292^{* * *}$ & $4.909^{* * *}$ & $5.363^{* * *}$ & $5.131^{* * *}$ & $5.424^{* * *}$ \\
& $(0.237)$ & $(0.358)$ & $(0.469)$ & $(0.405)$ & $(0.301)$ \\
Observations & & & & & \\
Past responsiveness & 1,332 & 453 & 445 & 434 & 879 \\
R-squared & All & $60 \%$ & $80 \%$ & $100 \%$ & $>60 \%$ \\
\hline & 0.079 & 0.092 & 0.099 & 0.095 & 0.084 \\
\hline & & & & &
\end{tabular}

Table 4: Operational transparency increases intended engagement among participants who, in the past, experienced at least a moderate level of responsiveness from the government (Study 3). Robust standard errors are provided in parentheses. All models additionally include an indicator variable for the respondent's stated political party. $* * *$, and $* * *$ signify significance at the $10 \%, 5 \%$ and $1 \%$ levels, respectively, relative to the baseline non-transparent condition.

Second, building on prior operational transparency research investigating the links between transparency to the beneficiaries of an employee's labor and the employee's willingness to exert effort (Buell et al. 2017, Grant 2007), we adapted measures originally intended to assess employees' perceptions of the impact of their efforts, and the degree to which they felt appreciated for the work that they were doing. Just as employees perceive that their efforts are more impactful and appreciated when they can see the people their efforts affect, we theorized that transparency into the outcomes resulting from one's engagement might increase perceptions that engaging was impactful, while engendering positivity toward 
oneself for engaging. Since such perceptions drive a willingness to exert effort among service employees, we reasoned the same mechanisms may be at play when any individual decides whether to engage in a coproductive process. To assess perceived impact of engaging, we used the following three items: "To what extent does solving this problem depend on your success or failure in engaging with the Boston local government?", "To what extent do the methods that you use to engage with the Boston local government have an impact on solving this problem?", and "To what extent does your level of performance in engaging with the Boston local government have an impact on solving this problem?" Responses were aggregated together to form a composite measure of perceived impact ( $\alpha=0.930$ ). Positivity toward oneself for engaging was measured with the question "How positive do you feel toward yourself for engaging with the Boston local government to solve this problem?" Finally, willingness to engage with the app in the future was measured by asking participants, "If given the opportunity, how likely would you be to use the Citizen's Connect app in the future?"

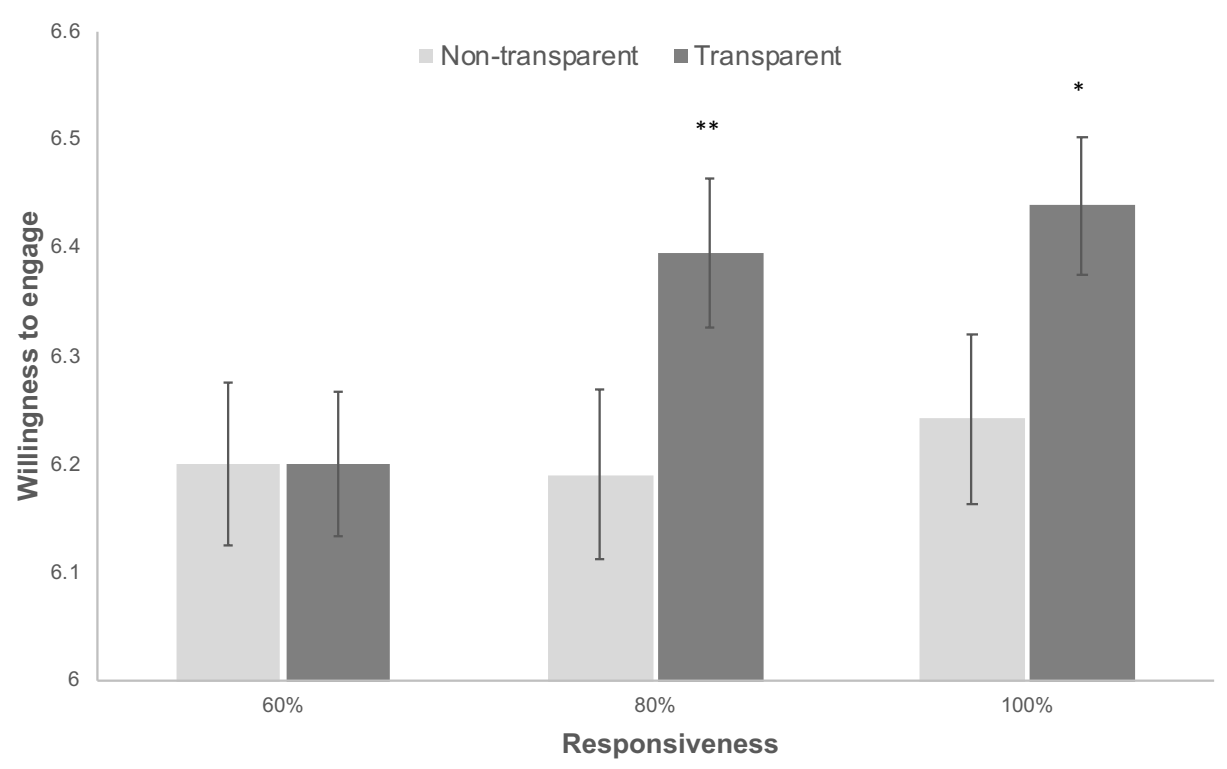

Figure 6: Operational transparency increases intended engagement among participants who, in the past, experienced at least a moderate level of responsiveness from the government (Study 3). All models are estimated with robust standard errors. $* * *$, and $* * *$ signify significance at the $10 \%, 5 \%$ and $1 \%$ levels, respectively, relative to the baseline non-transparent condition. Error bars represent Delta-method standard errors.

3.3.4. Control measures. We also captured demographic information about each participant, including their gender, age, level of education, monthly income, and their political interest, level of knowledge, party, and ideology, to control for individual differences that may influence one's attitudes toward government and their willingness to engage with it. At the end of the survey, we additionally asked "To what extent did 
you learn new things about what the Boston local government does," and a series of questions about the appeal of the graphics in the Citizen's Connect app: "I liked the graphics and images I saw in the app.", "The screen layout of the app was visually appealing.", "The app was attractive.", "The app appealed to my visual senses.", and "The app was aesthetically appealing." Summary statistics for the responses to all survey questions for participants across conditions are presented in the online appendix.

3.3.5. Empirical approach and results. We analyze the results of this experiment in three stages. First, we explore the effect of transparency on engagement for each level of past responsiveness, holding constant individual differences that may, themselves, serve as important drivers of one's willingness to engage. Next, we test the extent to which transparency covaries with each hypothesized driver of engagement and whether evidence exists for mediation along the hypothesized causal paths. Finally, we develop and analyze a structural equation model to trace out each causal chain.

We begin by exploring the effect of transparency on engagement for different levels of responsiveness. In Table 4, we use OLS regression, modelling an individual's willingness to engage as a function of the transparency treatment and all control variables, with robust standard errors clustered by respondent. Column (1) demonstrates that, controlling for other factors, transparency significantly increases willingness to engage among the entire sample of participants (coefficient $=0.129, p<0.05$ ). However, Columns $(2-4)$ demonstrate that transparency does not increase engagement for all levels of responsiveness. Consistent with the results of our field analysis, Column (2) demonstrates that transparency does not increase engagement among participants who, in the past, had experienced the government to have a low level of responsiveness (coefficient $=-0.000, p=0.99$ ). In contrast, Columns $(3-4)$ show that transparency does increase engagement among participants who were told that past responsiveness had been $80 \%$ (coefficient $=0.205, p<0.05$ ) or $100 \%$ (coefficient $=0.197, p<0.10$ ), respectively. Column (5) shows the effect of transparency is especially robust among all participants who experienced at least a moderate level of past government responsiveness (coefficient $=0.201, p<0.01$ ). Figure 6 plots these relationships graphically.

Next, we analyze whether transparency drives the proposed causal mechanisms highlighted in Section 3.3.3 above. In particular, we hypothesized that, consistent with prior research on consumers interacting with operations, operational transparency would increase perceptions of the government's effort, feelings of appreciation and reciprocity toward the government (Buell and Norton 2011, Buell et al. 2017), and in turn, trust and support it more (Mohan et al. 2019), driving increased engagement. We further hypothesized that, consistent with prior research on employees receiving a window into the effects of their efforts (Buell et al. 2017, Grant 2007), operational transparency would increase perceptions that engaging with the government was impactful, and would, bolster positive feelings toward oneself for engaging, in turn driving engagement. Finally, consistent with prior political science research linking political engagement to 
feelings of efficacy, and our earlier results linking increased trust and engagement to government responsiveness, we hypothesized that people would be more inclined to engage in the process, both directly, and indirectly through the causal pathways documented above, when their doing so in the past achieved desirable outcomes.

\begin{tabular}{|c|c|c|c|c|c|c|c|c|c|}
\hline & $\begin{array}{c}(1) \\
\text { Efficacy rating }\end{array}$ & $\begin{array}{c}(2) \\
\text { Engage } \\
\end{array}$ & $\begin{array}{c}\text { (3) } \\
\text { Effort }\end{array}$ & $\begin{array}{c}(4) \\
\text { Appreciation } \\
\end{array}$ & $\begin{array}{c}(5) \\
\text { Trust } \\
\end{array}$ & $\begin{array}{c}(6) \\
\text { Support }\end{array}$ & $\begin{array}{c}(7) \\
\text { Support }\end{array}$ & $\begin{array}{c}(8) \\
\text { Impact }\end{array}$ & $\begin{array}{c}(9) \\
\text { Positivity }\end{array}$ \\
\hline Transparency indicator & & $\begin{array}{c}0.156^{* * *} \\
(0.056)\end{array}$ & $\begin{array}{c}0.222^{* * *} \\
(0.053)\end{array}$ & $\begin{array}{c}0.302^{* * *} \\
(0.063)\end{array}$ & $\begin{array}{c}0.166^{* * *} \\
(0.057)\end{array}$ & $\begin{array}{c}0.057 \\
(0.065)\end{array}$ & $\begin{array}{c}-0.009 \\
(0.061)\end{array}$ & $\begin{array}{c}0.259^{* * *} \\
(0.062)\end{array}$ & $\begin{array}{c}0.256^{\star \star *} \\
(0.067)\end{array}$ \\
\hline Efficacy rating & & $\begin{array}{c}0.236^{* * *} \\
(0.024)\end{array}$ & $\begin{array}{c}0.269^{* * *} \\
(0.022)\end{array}$ & $\begin{array}{c}0.286^{* * *} \\
(0.025)\end{array}$ & $\begin{array}{c}0.299^{* * *} \\
(0.025)\end{array}$ & $\begin{array}{c}0.068^{* * *} \\
(0.026)\end{array}$ & $\begin{array}{l}-0.052^{* *} \\
(0.025)\end{array}$ & $\begin{array}{c}0.155^{\star * *} \\
(0.023)\end{array}$ & $\begin{array}{c}0.247^{* * *} \\
(0.027)\end{array}$ \\
\hline Trust & & & & & & & $\begin{array}{c}0.400^{* * *} \\
(0.037)\end{array}$ & & \\
\hline $80 \%$ responsiveness & $\begin{array}{c}0.731^{* * *} \\
(0.084)\end{array}$ & & & & & & & & \\
\hline $100 \%$ responsiveness & $\begin{array}{c}1.022^{* * *} \\
(0.091)\end{array}$ & & & & & & & & \\
\hline Female indicator & $\begin{array}{c}0.064 \\
(0.074)\end{array}$ & $\begin{array}{c}0.316^{* * *} \\
(0.056)\end{array}$ & $\begin{array}{c}0.204^{* * *} \\
(0.053)\end{array}$ & $\begin{array}{c}0.249 * * * \\
(0.063)\end{array}$ & $\begin{array}{c}0.149^{* * *} \\
(0.057)\end{array}$ & $\begin{array}{c}0.104 \\
(0.066)\end{array}$ & $\begin{array}{c}0.044 \\
(0.062)\end{array}$ & $\begin{array}{c}0.203^{* * *} \\
(0.061)\end{array}$ & $\begin{array}{c}0.261^{\star * *} \\
(0.066)\end{array}$ \\
\hline Age & $\begin{array}{l}0.006^{* *} \\
(0.003)\end{array}$ & $\begin{array}{l}0.005^{* *} \\
(0.002)\end{array}$ & $\begin{array}{c}0.002 \\
(0.002)\end{array}$ & $\begin{array}{l}-0.000 \\
(0.002)\end{array}$ & $\begin{array}{c}-0.003^{* *} \\
(0.002)\end{array}$ & $\begin{array}{l}-0.003 \\
(0.004)\end{array}$ & $\begin{array}{l}-0.002 \\
(0.003)\end{array}$ & $\begin{array}{c}0.005^{\star * *} \\
(0.002)\end{array}$ & $\begin{array}{c}0.001 \\
(0.003)\end{array}$ \\
\hline $\mathrm{Age}^{2}$ & $\begin{array}{c}-0.000^{* * *} \\
(0.000)\end{array}$ & $\begin{array}{l}0.000^{* *} \\
(0.000)\end{array}$ & $\begin{array}{l}0.000^{* *} \\
(0.000)\end{array}$ & $\begin{array}{l}0.000^{* *} \\
(0.000)\end{array}$ & $\begin{array}{l}0.000^{* *} \\
(0.000)\end{array}$ & $\begin{array}{c}0.000^{* * *} \\
(0.000)\end{array}$ & $\begin{array}{l}0.000^{* *} \\
(0.000)\end{array}$ & $\begin{array}{c}0.000^{* * *} \\
(0.000)\end{array}$ & $\begin{array}{c}0.000^{* * *} \\
(0.000)\end{array}$ \\
\hline Education level & $\begin{array}{l}-0.055^{\star} \\
(0.029)\end{array}$ & $\begin{array}{c}0.010 \\
(0.024)\end{array}$ & $\begin{array}{l}-0.003 \\
(0.023)\end{array}$ & $\begin{array}{l}0.029 \\
(0.028)\end{array}$ & $\begin{array}{l}0.040 \\
(0.025)\end{array}$ & $\begin{array}{l}0.058^{* *} \\
(0.027)\end{array}$ & $\begin{array}{l}0.042^{*} \\
(0.026)\end{array}$ & $\begin{array}{l}0.060^{* *} \\
(0.028)\end{array}$ & $\begin{array}{l}0.056^{*} \\
(0.029)\end{array}$ \\
\hline Income level & $\begin{array}{c}0.013 \\
(0.019)\end{array}$ & $\begin{array}{c}0.044^{* * *} \\
(0.015)\end{array}$ & $\begin{array}{c}0.024 \\
(0.016)\end{array}$ & $\begin{array}{c}0.014 \\
(0.018)\end{array}$ & $\begin{array}{l}0.035^{\star *} \\
(0.016)\end{array}$ & $\begin{array}{l}0.030^{*} \\
(0.018)\end{array}$ & $\begin{array}{c}0.016 \\
(0.017)\end{array}$ & $\begin{array}{l}0.008 \\
(0.018)\end{array}$ & $\begin{array}{l}-0.009 \\
(0.019)\end{array}$ \\
\hline Political knowledge & $\begin{array}{l}-0.163^{* *} \\
(0.067)\end{array}$ & $\begin{array}{l}0.040 \\
(0.060)\end{array}$ & $\begin{array}{l}-0.031 \\
(0.051)\end{array}$ & $\begin{array}{l}-0.032 \\
(0.060)\end{array}$ & $\begin{array}{l}-0.017 \\
(0.055)\end{array}$ & $\begin{array}{l}0.022 \\
(0.058)\end{array}$ & $\begin{array}{c}0.029 \\
(0.053)\end{array}$ & $\begin{array}{l}0.023 \\
(0.057)\end{array}$ & $\begin{array}{l}0.026 \\
(0.062)\end{array}$ \\
\hline Political interest & $\begin{array}{c}0.172^{* * *} \\
(0.058)\end{array}$ & $\begin{array}{c}0.050 \\
(0.052)\end{array}$ & $\begin{array}{c}0.030 \\
(0.045)\end{array}$ & $\begin{array}{c}0.018 \\
(0.050)\end{array}$ & $\begin{array}{c}0.016 \\
(0.047)\end{array}$ & $\begin{array}{c}0.031 \\
(0.051)\end{array}$ & $\begin{array}{c}0.025 \\
(0.047)\end{array}$ & $\begin{array}{c}0.081 \\
(0.050)\end{array}$ & $\begin{array}{c}0.037 \\
(0.055)\end{array}$ \\
\hline Political ideology & $\begin{array}{l}-0.112^{*} \\
(0.060)\end{array}$ & $\begin{array}{l}-0.016 \\
(0.039)\end{array}$ & $\begin{array}{c}0.018 \\
(0.040)\end{array}$ & $\begin{array}{c}0.039 \\
(0.045)\end{array}$ & $\begin{array}{c}0.048 \\
(0.043)\end{array}$ & $\begin{array}{c}-0.187^{* * *} \\
(0.046)\end{array}$ & $\begin{array}{c}-0.206^{* \star *} \\
(0.040)\end{array}$ & $\begin{array}{l}0.081^{*} \\
(0.044)\end{array}$ & $\begin{array}{c}0.050 \\
(0.050)\end{array}$ \\
\hline Constant & $\begin{array}{c}4.698^{\star * *} \\
(0.259)\end{array}$ & $\begin{array}{c}4.062^{* * *} \\
(0.258)\end{array}$ & $\begin{array}{c}3.955^{* * *} \\
(0.234)\end{array}$ & $\begin{array}{c}3.962^{* * *} \\
(0.276)\end{array}$ & $\begin{array}{c}3.490 * * * \\
(0.252)\end{array}$ & $\begin{array}{c}5.085^{* * *} \\
(0.279)\end{array}$ & $\begin{array}{c}3.688^{* * *} \\
(0.302)\end{array}$ & $\begin{array}{c}3.511^{* * *} \\
(0.271)\end{array}$ & $\begin{array}{c}3.837^{\star * *} \\
(0.309)\end{array}$ \\
\hline Observations & 1,336 & 1,332 & 1,335 & 1,335 & 1,336 & 1,336 & 1,336 & 1,336 & 1,333 \\
\hline R-squared & 0.123 & 0.164 & 0.163 & 0.148 & 0.176 & 0.200 & 0.299 & 0.083 & 0.105 \\
\hline
\end{tabular}

Table 5: Operational transparency and feelings of efficacy increase perceived effort, feelings of government appreciation, trust in the government, the perception that engaging with the government is impactful, and positive feelings toward oneself for engaging (Study 3). Robust standard errors are provided in parentheses. All models additionally include an indicator variable for the respondent's stated political party. $* * *$, and $* * *$ signify significance at the $10 \%, 5 \%$ and $1 \%$ levels, respectively, relative to the baseline non-transparent condition.

In Table 5, Column (1), we find that individual feelings of efficacy are significantly higher when the government has been $80 \%$ (coefficient $=0.731, p<0.01$ ) or $100 \%$ (coefficient $=1.022, p<0.01)$ responsive in the past, relative to when it was only $60 \%$ responsive. Column (2) shows that a person's efficacy rating is a potent driver of an individual's willingness to engage in the future (coefficient $=0.236, p<0.01$ ), which is separate from the effects of operational transparency (coefficient $=0.156, p<0.01$ ). Columns $(3-5$ ) demonstrate that feelings of efficacy and operational transparency drive an individual's perception of the government's effort, feelings of appreciation toward the government, and trust in the government $(p s<0.01)$. Column (6) shows that although feelings of efficacy drives support for government (coefficient $=0.068$, $p<0.01$ ), transparency doesn't do so directly (coefficient $=0.057, p=0.378$ ). However, Column (7) shows 
how trust is an important driver of support (coefficient $=0.400, p<0.01$ ). Finally, Columns (8) and (9) demonstrate how feelings of efficacy and operational transparency drive the perceptions that one's engagement with the government is impactful and positive feelings toward oneself for engaging $(p s<0.01)$.

\begin{tabular}{|c|c|c|c|c|c|c|c|c|}
\hline & $\begin{array}{c}(1) \\
\text { Engage }\end{array}$ & $\begin{array}{c}(2) \\
\text { Engage } \\
\end{array}$ & $\begin{array}{c}(3) \\
\text { Engage } \\
\end{array}$ & $\begin{array}{c}(4) \\
\text { Engage } \\
\end{array}$ & $\begin{array}{c}(5) \\
\text { Engage } \\
\end{array}$ & $\begin{array}{c}(6) \\
\text { Engage } \\
\end{array}$ & $\begin{array}{c}(7) \\
\text { Engage } \\
\end{array}$ & $\begin{array}{c}(8) \\
\text { Engage } \\
\end{array}$ \\
\hline Transparency indicator & $\begin{array}{c}0.156^{* * *} \\
(0.056)\end{array}$ & $\begin{array}{c}0.047 \\
(0.050)\end{array}$ & $\begin{array}{c}0.009 \\
(0.048)\end{array}$ & $\begin{array}{c}0.015 \\
(0.047)\end{array}$ & $\begin{array}{c}0.018 \\
(0.046)\end{array}$ & $\begin{array}{c}0.057 \\
(0.052)\end{array}$ & $\begin{array}{c}0.036 \\
(0.049)\end{array}$ & $\begin{array}{c}0.009 \\
(0.046)\end{array}$ \\
\hline Perceived effort & & $\begin{array}{c}0.482^{* * *} \\
(0.036)\end{array}$ & $\begin{array}{c}0.197^{\star \star *} \\
(0.047)\end{array}$ & $\begin{array}{c}0.134^{* * *} \\
(0.048)\end{array}$ & $\begin{array}{c}0.129^{* * *} \\
(0.049)\end{array}$ & & & $\begin{array}{l}0.056 \\
(0.050)\end{array}$ \\
\hline Appreciation & & & $\begin{array}{c}0.335^{\star \star *} \\
(0.044)\end{array}$ & $\begin{array}{c}0.259^{\star \star \star} \\
(0.042)\end{array}$ & $\begin{array}{c}0.253^{\star \star *} \\
(0.041)\end{array}$ & & & $\begin{array}{c}0.165^{\star \star \star} \\
(0.045)\end{array}$ \\
\hline Trust in government & & & & $\begin{array}{c}0.183^{* * *} \\
(0.041)\end{array}$ & $\begin{array}{c}0.132^{* * *} \\
(0.041)\end{array}$ & & & $\begin{array}{c}0.131^{* * *} \\
(0.041)\end{array}$ \\
\hline Support for government & & & & & $\begin{array}{c}0.148^{* * *} \\
(0.027)\end{array}$ & & & $\begin{array}{c}0.141^{* * *} \\
(0.026)\end{array}$ \\
\hline Perceived impact & & & & & & $\begin{array}{c}0.375^{* * *} \\
(0.032)\end{array}$ & $\begin{array}{c}0.125^{\star * *} \\
(0.037)\end{array}$ & $\begin{array}{c}0.017 \\
(0.037)\end{array}$ \\
\hline Positivity toward self & & & & & & & $\begin{array}{c}0.328^{* * *} \\
(0.037)\end{array}$ & $\begin{array}{c}0.176^{* * *} \\
(0.039)\end{array}$ \\
\hline Efficacy rating & $\begin{array}{c}0.236^{* * *} \\
(0.024)\end{array}$ & 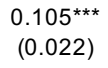 & $\begin{array}{c}0.086^{* * *} \\
(0.020)\end{array}$ & $\begin{array}{c}0.070^{* * *} \\
(0.020)\end{array}$ & $\begin{array}{c}0.078^{* * *} \\
(0.019)\end{array}$ & $\begin{array}{c}0.177^{\star \star \star} \\
(0.022)\end{array}$ & $\begin{array}{c}0.137^{* * *} \\
(0.021)\end{array}$ & $\begin{array}{c}0.079^{* * *} \\
(0.020)\end{array}$ \\
\hline Female indicator & $\begin{array}{c}0.316^{* * *} \\
(0.056)\end{array}$ & $\begin{array}{c}0.216^{* * *} \\
(0.050)\end{array}$ & $\begin{array}{c}0.191^{* * *} \\
(0.048)\end{array}$ & $\begin{array}{c}0.196^{* * *} \\
(0.047)\end{array}$ & $\begin{array}{c}0.189^{* \star *} \\
(0.047)\end{array}$ & $\begin{array}{c}0.240^{* * *} \\
(0.052)\end{array}$ & $\begin{array}{c}0.208^{* * *} \\
(0.049)\end{array}$ & $\begin{array}{c}0.180^{* * *} \\
(0.045)\end{array}$ \\
\hline Age & $\begin{array}{l}0.005^{* *} \\
(0.002)\end{array}$ & $\begin{array}{c}0.004^{* * *} \\
(0.001)\end{array}$ & $\begin{array}{c}0.005^{\star \star *} \\
(0.002)\end{array}$ & $\begin{array}{c}0.006^{* \star *} \\
(0.002)\end{array}$ & $\begin{array}{c}0.006^{* * *} \\
(0.002)\end{array}$ & $\begin{array}{l}0.003^{*} \\
(0.002)\end{array}$ & $\begin{array}{c}0.004^{* * *} \\
(0.001)\end{array}$ & $\begin{array}{c}0.006^{* \star *} \\
(0.002)\end{array}$ \\
\hline $\mathrm{Age}^{2}$ & $\begin{array}{l}0.000^{* *} \\
(0.000)\end{array}$ & $\begin{array}{c}0.000 \\
(0.000)\end{array}$ & $\begin{array}{l}0.000 \\
(0.000)\end{array}$ & $\begin{array}{l}-0.000 \\
(0.000)\end{array}$ & $\begin{array}{c}-0.000^{* * *} \\
(0.000)\end{array}$ & $\begin{array}{l}-0.000 \\
(0.000)\end{array}$ & $\begin{array}{l}-0.000 \\
(0.000)\end{array}$ & $\begin{array}{c}-0.000^{* \star *} \\
(0.000)\end{array}$ \\
\hline Education level & $\begin{array}{c}0.010 \\
(0.024)\end{array}$ & $\begin{array}{c}0.012 \\
(0.022)\end{array}$ & $\begin{array}{c}0.002 \\
(0.021)\end{array}$ & $\begin{array}{l}-0.003 \\
(0.020)\end{array}$ & $\begin{array}{l}-0.010 \\
(0.020)\end{array}$ & $\begin{array}{l}-0.012 \\
(0.022)\end{array}$ & $\begin{array}{l}-0.015 \\
(0.021)\end{array}$ & $\begin{array}{l}-0.017 \\
(0.020)\end{array}$ \\
\hline Income level & $\begin{array}{c}0.044^{\star * *} \\
(0.015)\end{array}$ & $\begin{array}{l}0.033^{* *} \\
(0.014)\end{array}$ & $\begin{array}{c}0.035^{\star \star *} \\
(0.013)\end{array}$ & $\begin{array}{l}0.031^{* *} \\
(0.013)\end{array}$ & $\begin{array}{l}0.029^{* *} \\
(0.013)\end{array}$ & $\begin{array}{c}0.041^{* * *} \\
(0.015)\end{array}$ & $\begin{array}{c}0.046^{\star * *} \\
(0.014)\end{array}$ & $\begin{array}{l}0.033^{* *} \\
(0.013)\end{array}$ \\
\hline Political knowledge & $\begin{array}{c}0.040 \\
(0.060)\end{array}$ & $\begin{array}{c}0.055 \\
(0.052)\end{array}$ & $\begin{array}{l}0.057 \\
(0.051)\end{array}$ & $\begin{array}{l}0.056 \\
(0.050)\end{array}$ & $\begin{array}{c}0.051 \\
(0.049)\end{array}$ & $\begin{array}{c}0.032 \\
(0.053)\end{array}$ & $\begin{array}{c}0.027 \\
(0.054)\end{array}$ & $\begin{array}{c}0.040 \\
(0.049)\end{array}$ \\
\hline Political interest & $\begin{array}{c}0.050 \\
(0.052)\end{array}$ & $\begin{array}{c}0.035 \\
(0.045)\end{array}$ & $\begin{array}{c}0.038 \\
(0.044)\end{array}$ & $\begin{array}{c}0.038 \\
(0.043)\end{array}$ & $\begin{array}{c}0.035 \\
(0.043)\end{array}$ & $\begin{array}{c}0.019 \\
(0.046)\end{array}$ & $\begin{array}{c}0.027 \\
(0.048)\end{array}$ & $\begin{array}{c}0.030 \\
(0.043)\end{array}$ \\
\hline Political ideology & $\begin{array}{l}-0.016 \\
(0.039)\end{array}$ & $\begin{array}{l}-0.025 \\
(0.033)\end{array}$ & $\begin{array}{l}-0.033 \\
(0.031)\end{array}$ & $\begin{array}{l}-0.037 \\
(0.031)\end{array}$ & $\begin{array}{l}-0.006 \\
(0.029)\end{array}$ & $\begin{array}{l}-0.046 \\
(0.033)\end{array}$ & $\begin{array}{l}-0.035 \\
(0.034)\end{array}$ & $\begin{array}{l}-0.008 \\
(0.030)\end{array}$ \\
\hline Constant & $\begin{array}{c}4.062^{* * *} \\
(0.258)\end{array}$ & $\begin{array}{c}2.159^{\text {*** }}(0.273)\end{array}$ & $\begin{array}{c}1.955^{\star * *} \\
(0.264)\end{array}$ & $\begin{array}{c}1.862^{* * *} \\
(0.264)\end{array}$ & $\begin{array}{c}1.336^{* * *} \\
(0.280)\end{array}$ & $\begin{array}{c}2.744^{* * *} \\
(0.267)\end{array}$ & $\begin{array}{c}2.352^{* * *} \\
(0.260)\end{array}$ & $\begin{array}{c}1.276^{\star \star \star *} \\
(0.275)\end{array}$ \\
\hline Observations & 1,332 & 1,331 & 1,331 & 1,331 & 1,331 & 1,332 & 1,329 & 1,328 \\
\hline R-squared & 0.164 & 0.341 & 0.399 & 0.413 & 0.434 & 0.305 & 0.374 & 0.456 \\
\hline
\end{tabular}

Table 6: Perceived effort, appreciation of the government, trust in government, support for government, the perception that engaging with government is impactful, feelings of positivity toward oneself for engaging with government, and feelings of efficacy increase willingness to engage with the government (Study 3). Robust standard errors are provided in parentheses. All models additionally include an indicator variable for the respondent's stated political party. ${ }^{*}, * *$, and $* * *$ signify significance at the $10 \%, 5 \%$ and $1 \%$ levels, respectively.

In Table 6, we iteratively test the links between each of the hypothesized mechanisms outlined above and engagement. Columns (1-2) demonstrate how transparency is a significant driver of engagement (coefficient $=0.156, p<0.01$ ), but that the effect is mediated by perceived effort (coefficient $=0.047$, $p=0.348$ ), which itself is a significant driver of engagement (coefficient $=0.482, p<0.01$ ). Column (3) shows how, consistent with prior research and our hypothesis, the effect of perceived effort on engagement is mediated by feelings of appreciation (coefficient $=0.197, p<0.01$ ), which itself is a potent driver of 
engagement (coefficient $=0.335, p<0.01$ ). Columns (4) and (5) provide evidence of how this causal pathway affects engagement by increasing trust (coefficient $=0.183, p<0.01$ ) and support (coefficient $=$ $0.148, p<0.01)$. Column (6) shows the beginning of a second causal pathway, wherein the effects of transparency increase engagement through the perception that one's engagement is impactful (coefficient $=0.375, p<0.01$ ), which in Column (7), in turn, drives engagement through feelings of positivity for engaging (coefficient $=0.328, p<0.01$ ). Finally, Column $(8)$ demonstrates how, in the fully controlled model, engagement is separately driven by feelings of appreciation for government (coefficient $=0.165, p<0.01$ ), trust in government (coefficient $=0.131, p<0.01)$, and support for government $($ coefficient $=0.141, p<0.01)$, as well as the positivity one feels toward themselves for engaging with government (coefficient $=0.176$, $p<0.01$ ), and one's own perceptions of self-efficacy (coefficient $=0.079, p<0.01$ ).

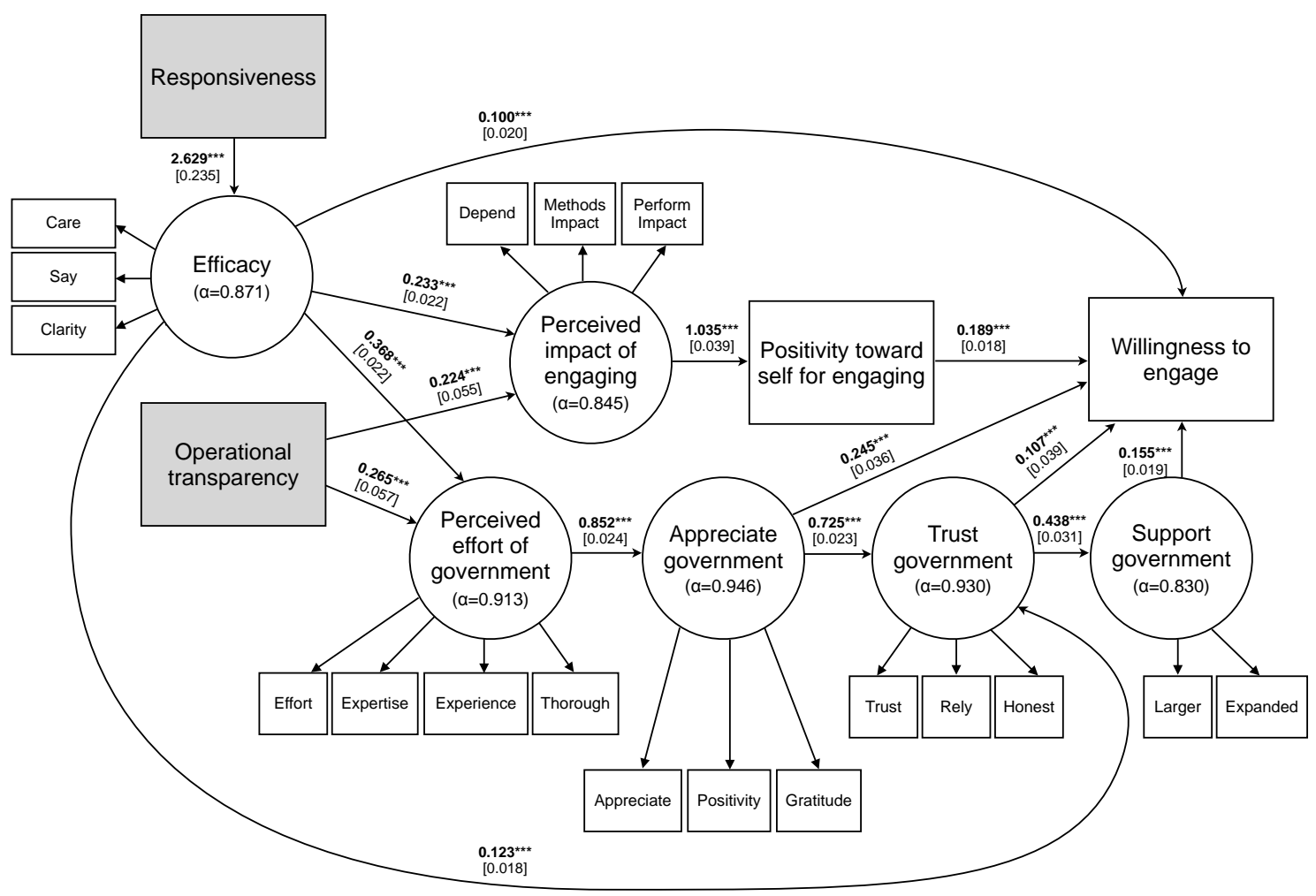

Figure 7: Structural equation model of mechanisms linking past responsiveness and operational transparency to one's willingness to engage (Study 3). Factors that were exogenously manipulated in the experiment are shown in grey boxes. The results demonstrate that an individual's willingness to engage is driven by the efficacy they feel (whether they believe they have agency in affecting outcomes of interest), as well as their perceptions of the organization with which their engaging (e.g., their perceptions of its effort, their appreciation of it, their trust in it, and their support for it), and their perceptions of the impact of their engagement (whether their engagement affects outcomes, and the degree of positivity they feel toward themselves for engaging). When past responsiveness is low, it suppresses one's willingness to engage along all three causal pathways. 
Figure 7 provides a visual summary of a structural equation model that provides strong support for the three hypothesized causal pathways explaining the links among operational transparency, past responsiveness, and willingness to engage with the government in the future. The model has a high Comparative Fit Index $(\mathrm{CFI})=0.915$ and a low Root Mean Squared Error of Approximation $(\mathrm{RMSEA})=$ 0.088 , suggesting strong support. In summary, the model suggests that past responsiveness influences feelings of efficacy, which influences willingness to engage, both directly (coefficient $=0.100, p<0.01$ ), and indirectly, by increasing the perceived effort of government (coefficient $=0.368, p<0.01$ ), and the perceived impact of engaging with government (coefficient $=0.233, p<0.01)$.

Operational transparency increases willingness to engage by increasing perceptions of the government's efforts (coefficient $=0.265, p<0.01$ ), which in turn increases feelings of appreciation toward the government (coefficient $=0.852, p<0.01$ ). Feelings of appreciation toward the government influences engagement both directly (coefficient $=0.245, p<0.01$ ), and indirectly by increasing feelings of trust (coefficient $=0.725, p<0.01)$, and in turn, support for the government (coefficient $=0.438, p<0.01)$. We find that trust (coefficient $=0.107, p<0.01$ ) and support (coefficient $=0.155, p<0.01$ ) both separately drive engagement. The results also suggest that operational transparency increases the perceived impact of engaging with government (coefficient $=0.224, p<0.01$ ), which in turn engenders positivity toward oneself for engaging with government (coefficient $=1.035, p<0.01$ ), which results in increased willingness to engage (coefficient $=0.189, p<0.01$ ). In sum, we find that providing transparency into a responsive operation drives a co-producer's increased level of engagement by helping them feel more efficacious, that the organization with which they are engaging is an effortful and trusted engagement partner, and that their engagement is important and meaningful.

3.3.6 Robustness test. In a separate study, presented in full in the online appendix, we replicate the procedure of Study 3 in the $80 \%$ responsiveness condition, using messaging to directly manipulate perceived effort and perceived impact in a 2(transparency: non-transparent, transparent) x 2(messaging: none, low effort and impact messaging) design, with 2,894 online participants (50.2\% female, $M_{\text {age }}=35.7$ ). The results replicate the main effects of transparency on all dependent and interstitial process measures described in Study 3, but they also provide further process evidence through the direct manipulation of perceived effort and impact. When perceived impact and perceived effort are downwardly manipulated, by informing participants that "In addressing the issue, the public works team didn't spend much time planning and didn't physically exert themselves," and that "instead of reporting the issue to the government, you could have picked up the trash yourself," trust and willingness to engage decline, along with the interstitial process measures. When participants experience messaging and operational transparency, the dependent measures and interstitial process measures are improved relative to the messaging-only condition, though 
not to the same level as under transparency in the absence of messaging. Finally, we observe an interaction, wherein the effects of operational transparency on trust and engagement are stronger when messaging is used to downwardly manipulate perceptions of government effort and perceptions of engaging with government. This pattern suggests that the gains from operational transparency may be largest where people have low perceptions of the government as an effortful and impactful engagement partner.

3.3.7 Discussion. Taken together, these results make three important contributions to the literature on co-production. First, they highlight how when a consumer is in a co-productive relationship with an organization like the government, operational transparency can enact--in the same person--the mutually reinforcing set of causal mechanisms that exist among customers and employees in a traditional service interaction. We find that transparency simultaneously increases engagement by bolstering attitudes toward the government, and by helping the individual feel that their own engagement is impactful and rewarding. Second, they highlight the important contingent effects of an organization's past level of responsiveness to an individual's future willingness to engage. When past levels of government responsiveness have been moderate to high, participants report feeling more efficacious, which influences their willingness to engage both directly, as well as indirectly through the causal channels through which operational transparency increases engagement. As a consequence, operational transparency can only lead to increased levels of engagement when past levels of responsiveness leave an individual feeling sufficiently efficacious to perceive the organization's efforts worthy of their engagement, and the engagement sufficiently impactful to be worthy of their time. Finally, the results demonstrate the role of support for the organization, as well as perceptions of the effort it expends in responding to requests, and the impact of engaging with it, in affecting an individual's willingness to engage. We find that an individual's degree of support for the government is driven by whether it engages in operational transparency and the degree of efficacy they feel from their past interactions with it, which influences support through their level of trust in the organization, but also by outside factors that drive individual differences in levels of support. Relatedly, we find that the potential of operational transparency to bolster trust and engagement is higher in contexts where people have low perceptions of the organization as an effortful partner when it responds to requests, and low perceptions of the impact of their own engagement - perceptions that operational transparency can offset.

\section{General discussion}

Through three studies, conducted in the field and in the lab, we investigated the effects of both operational transparency and government responsiveness on people's trust in and engagement with

government services. Study 1 showed that when the City of Boston introduced operational transparency by providing residents with photos of the work it performed in response to their service requests, residents 
increased their subsequent levels of engagement - submitting $60 \%$ more service requests in $38 \%$ more categories over the ensuing 13 months. Moreover, we find that the effects were strongest among residents who had previously experienced the government to be at least moderately responsive to their requests in the past. Study 2 builds on these results, by showing that when Boston residents interacted with a website that visually depicted resident service requests and efforts by the city to resolve them, reported levels of trust in and support for government increased. However, when transparency revealed a growing backlog of unresolved service requests, portraying government to be less responsive, residents reported being no more nor less trusting and supportive than residents who had not experienced operational transparency.

These studies highlight that transparency alone is not a panacea for trust and engagement - it must be paired with a responsive operation for benefits to emerge. Study 3 replicates and extends the results from the first two studies by mapping the mechanisms linking operational transparency and responsiveness to trust and engagement. We find that in co-productive settings where the customer takes on the roles of both consumer and producer of the service, operational transparency increases perceptions that the organization is expending effort on the customer's behalf and thus is a trusted partner for engagement, as well as heightening customers' beliefs that their engagement is meaningful and worthwhile. Moreover, we document a critical role for government responsiveness, which by increasing feelings of personal efficacy both directly - and indirectly (through perceived effort and impact) - increases people's willingness to engage. In this way, operational transparency in co-productive settings, where successful service delivery depends on the customer trusting and engaging with the organization, activates similar causal chains to those separately experienced by customers and employees in other service contexts.

\subsection{Limitations and Opportunities for Future Research}

Like many empirical studies that leverage field data to investigate phenomena in practice, we acknowledge that the present research has limitations that offer opportunities for future research. For example, Study 1 leverages proprietary data from the City of Boston to test the effects of operational transparency in promoting resident engagement, exploiting variation imposed by both the resident and the public works team to conduct the analysis. Although our econometric method allows us to isolate the effects of interest (as described in Section 3.1.8), we acknowledge that even stronger evidence would be obtained from a fully-randomized controlled trial, in which, for example, every resident's app had the capacity to display operational transparency, and public works teams were assigned to randomize whether to post a photo on an issue-by-issue basis. Moreover, Study 2, which also relies on data from the City of Boston to test the effects of operational transparency and responsiveness on resident perceptions, manipulates perceptions of responsiveness by varying the content of the transparency itself. Although an ex-post 
manipulation check suggests the effectiveness of this approach, future research might replicate our analysis in multiple cities as a complementary strategy for examining the role of government responsiveness.

Research could also build on the present studies by further testing both the content and composition of operational transparency. For example, from a content perspective, prior research on operational transparency has focused on making operational processes transparent (e.g., showing a city worker filling a pothole), while the present work instead focuses on making the outcomes themselves transparent (e.g., showing the filled pothole). Future work could shed light on the factors that determine whether providing transparency into the process versus the outcome is more likely to improve perceptions and engagement. Given the high degree of opacity in government operations, merely showing outcomes may be sufficient to reshape peoples' understanding and appreciation of the work occurring behind the scenes; in more customer-facing operations where outcomes are readily observed, however, providing a window into processes themselves may be more effective. Relatedly, future work is needed to explore how the specific design of operational transparency influences customer perceptions and behaviors - such as when the mere provision of information is sufficient, or visual imagery is required. Indeed, in the online appendix we present a study modeled on the Citizen's Connect application, which suggests that in the government context, trust and support are most positively impacted when visual imagery is provided; however, in some contexts, the mere provision of information may be sufficient to affect customer perceptions. For example, online package tracking often provides a window into the process without providing visual imagery of the package itself. It is possible that in contexts where trust is high and service processes are already well known, the provision of information is sufficient to reshape perceptions and behaviors, but in contexts where trust is low and the processes operating behind the scenes are poorly understood (such as government), the use of visual imagery is more impactful. By delving into these moderators, future research could also inform successful implementation of operational transparency in a wider array of contexts.

\subsection{Managerial implications}

\subsubsection{Operational transparency can be an effective way to build trust and engender long-term} engagement in co-productive services. The present research reveals how a relatively low-cost modification to the design of co-productive service interactions - designing operational transparency into the interaction itself - can affect consumers' experience and engagement with the operation. We conduct this research in the context of government services, a domain where trust and engagement are approaching historically-low levels, and where even expensive interventions can have a miniscule effect. For example, some campaigns in the 2020 federal election cycle reported spending $\$ 25.00$ to 75.00 in direct marketing costs to attract a single $\$ 1.00$ donation (Goldmacher and Lerer 2019). Our results demonstrate that simply showing the 
otherwise-hidden work that government performs in service of its citizen requests can motivate long-lasting changes in engagement. Boston residents who were exposed to operational transparency, seeing at least a single photo of the work government performed in response to one of their requests, became significantly more engaged, submitting $60 \%$ more service requests in $38 \%$ more categories over the ensuing 13 months, and exhibiting measurable differences even 11 months after their initial exposure. The long-lasting nature of these effects suggests that operational transparency may help to reframe how residents think about their interactions with government, in turn reshaping the way they engage in those interactions.

4.2.2 Showing is more motivating than telling. We note that in all three of the primary studies presented in this paper, the baseline is not a no-information condition; in all cases, the effects of operational transparency we document are over and above the effects of simply telling people about the work being performed. For example, residents in the control condition of the Citizen's Connect study received a textual notification of the work that government performed in response to their requests, and residents in the control condition of the Daily Brief study observed counts of the number of open, recently opened, and recently closed service requests. The only difference in these experimental manipulations was that rather than being merely told about the work performed by the government, people in the operationally transparent conditions were also shown that work. Indeed, in a separate study reported in the online appendix, we separate the components of operational transparency and find that people need to see the work being requested and performed for its benefits to arise.

4.2.3 Responsiveness remains a critical driver of trust and engagement. Across all three studies, operational transparency led to increased trust and engagement only when government was at least moderately responsive to citizens' requests. People who experienced low levels of government responsiveness did not show increased engagement in response to operational transparency, and those for whom transparency revealed the growing backlog of government requests were no more nor less trusting and supportive than those who experienced no transparency at all. In short, no amount of transparency is likely to build trust and engagement in a non-responsive operation. At the same time, we note that none of our studies demonstrated transparency undermining trust and engagement. This pattern of results suggests that the costs of being more fully transparent in operations may be lower than some managers perceive. Indeed, to the extent that transparency can afford more opportunities to collect feedback, and can itself be a potent motivator of employee behavior and change (Buell 2019), enacting operational transparency may accelerate improvements in operational responsiveness.

4.2.4 The potential gains from enacting operational transparency may be highest in contexts where peoples' perceptions of the organization as an effortful and impactful engagement partner are lowest. By providing a window into the otherwise-hidden work being performed inside the organization, operational 
transparency increases peoples' perceptions of the effort expended in response to their engagement, and the impact of their engagement itself. Consistently, our experimental results suggest that the effects of operational transparency on trust and engagement can be strongest when it is used to disconfirm peoples' low perceptions.

\subsubsection{Operational transparency activates a similar set of processes in co-producers as it separately} activates in customers and employees. Customers in co-produced service settings - such as government take on the role of both customers and producers of the service; our results suggest that despite this dual role, operational transparency enacts a similar set of processes it has separately been shown to induce in customers and employees. As with customers in other settings, we find that operational transparency into the hidden work taking place behind the scenes in co-produced settings increases perceived effort and appreciation for the organization, in turn contributing to heightened trust and greater engagement. We also observe that, as with employees, revealing the hidden value creation that arises from people's own effort causes them to feel that their engagement is more meaningful, and to feel more positively about themselves for engaging. Taken together, these results suggest that in co-produced settings, additional benefits may arise when organizations allow employees to see how their work fosters the co-productive engagement of customers. Providing such a window may serve as an additional motivational driver for employees in coproduced settings, particularly those where customer engagement is critical for achieving successful outcomes. The ubiquity of these dynamics in people-centric operations - hidden work occurring behind the scenes that is not fully appreciated, and consumer engagement leading to meaningfully better outcomes suggests that the results we observe in government contexts in the present research are likely to generalize to a broad array of service operations.

\subsection{Conclusion}

All services rely, at least to a certain extent, on customer inputs (Sampson and Froehle 2006), but services are co-produced in a growing number of settings, with successful outcomes reliant on fostering the trust and engagement of consumers (Roels 2014). Although the work performed by service employees in many of these contexts frequently occurs behind the scenes, our results suggest that making that effort more operationally transparent can lead to higher levels of consumer trust and engagement. The present research is conducted in government services, a massive economic sector where trust and engagement are at or near historic lows, but the psychological processes driving our results likely apply to a much broader set of coproduced contexts where successful outcomes rely on the trust and meaningful engagement of customers. For example, successful outcomes in education, medicine, and government require the trust and engagement of students, patients, and citizens to invest in their learning, well-being, and communities. We 
suggest that these necessary consumer investments may be promoted by providing transparency into the work taking place behind the scenes in support of their engagement: the work of teachers planning lessons and grading homework; the work of physicians conducting tests to determine the best courses of treatment; and the work of civic employees responding to citizen requests to help the community improve. We argue, and our results suggest, that transparent operations can foster better relationships with stakeholders and promote a deeper level of engagement that creates better outcomes for everyone involved.

\section{References}

Ambady N, Rosenthal R (1993) Half a minute: Predicting teacher evaluations from thin slices of nonverbal behavior and physical attractiveness. J. Pers. Soc. Psychol. 64:431-441.

Benjamin DJ, Shapiro JM (2009) Thin-slice forecasts of gubernatorial elections. Rev. Econ. Stat. 91:523536.

van Beuningen J, de Ruyter K, Wetzels M, Streukens S (2008) Customer self-efficacy in technologybased self-service: Assessing between- and within-person differences. J. Serv. Res. 11(4):407-428.

Bowler S, Karp JA (2004) Politicians, scandals, and trust in government. Polit. Behav. 26(3):271-287.

Bray R (2018) Operational transparency: Showing when work gets done

Brus H, Van De Laar M, Taal E, Rasker J, Wiegman O (1999) Determinants of compliance with medication in patients with rheumatoid arthritis: The importance of self-efficacy expectations. Patient Educ. Couns.

Buell RW (2019) Operational transparency. Harv. Bus. Rev. 97(4).

Buell RW, Choi M (2019) Improving customer compatibility with operational transparency (Boston, MA).

Buell RW, Kalkanci B (2019) How transparency into internal and external responsibility initiatives influences consumer choice. Manage. Sci. Forthcoming.

Buell Ryan W., Kim T, Tsay CJ (2017) Creating reciprocal value through operational transparency. Manage. Sci. 63(6):1673-1695.

Buell R.W., Kim T, Tsay CJ (2017) Creating reciprocal value through operational transparency. Manage. Sci. 63(6):1673-1695.

Buell RW, Mariadassou S, Zheng Y (2019) Relative performance transparency: Effects on sustainable purchase and consumption behavior (Boston, MA).

Buell RW, Norton MI (2011) The labor illusion: How operational transparency increases perceived value. Manage. Sci. 57(9):1564-1579.

Campbell A, Converse P, Miller W, Stokes D (1960) The American Voter (University of Chicago Press, Chicago, IL). 
Chinander KR, Schweitzer ME (2003) The input bias: The misuse of input information in judgments of outcomes. Organ. Behav. Hum. Decis. Process. 91(2):243-253.

Citrin J (1974) Comment: The political relevance of trust in government. Am. Polit. Sci. Rev. 68(3):973988.

City of Boston (2016) Commonwealth Connect. Retrieved (February 18, 2016), http://www.cityofboston.gov/doit/apps/commonwealthconnect.asp.

Code for America (2019) Our vision, mission, values, and operating principles. Retrieved (August 5, 2019), http://www.codeforamerica.org/values.

Cui R, Li J, Zhang D (2018) Discrimination with incomplete information in the sharing economy: Evidence from field experiments on Airbnb. Manage. Sci. (Forthcoming):38.

Desilver D (2017) U.S. trails most developed countries in voter turnout (Washington, D.C.).

Dimock M, Doherty C, Kohut A (2013) Majority says the federal government threatens their personal rights (Washington, D.C.).

Finkel SE (1985) Reciprocal effects of participation and political efficacy: A panel analysis. Am. J. Pol. Sci.

Fox RL, Lawless JL (2010) If only they'd ask: Gender, recruitment, and political ambition. J. Polit.

Goldmacher S, Lerer L (2019) New democratic debate rules will distort priorities, some campaigns say. New York Times (May 31) https://www.nytimes.com/2019/05/30/us/politics/democratic-debaterules.html.

Grant AM (2007) Relational job design and the motivation to make a prosocial difference. Acad. Manag. Rev. 32:393-417.

Grant AM, Campbell EM, Chen G, Cottone K, Lapedis D, Lee K (2007) Impact and the art of motivation maintenance: The effects of contact with beneficiaries on persistence behavior. Organ. Behav. Hum. Decis. Process. 103(1):53-67.

Hetherington MJ, Husser JA (2012) How Trust Matters: The Changing Political Relevance of Political Trust. Am. J. Pol. Sci.

Hicks R, Tingley D (2011) Causal mediation analysis. Stata J. 11(4):1-15.

Imai K, Keele L, Tingley D (2010) A general approach to causal mediation analysis. Psychol. Methods 15(4):309-34.

Ingraham C (2017) Somebody just put a price tag on the 2016 election and it's a doozy. The Washington Post (April 4).

Jennings MK, Stoker L (2004) Social trust and civic engagement across time and generations. Acta Polit. 39(4):342-379.

Kalkanci B, Ang E, Plambeck E (2018) Managing social and environmental impacts with voluntary vs. mandatory disclosure to investors. Manage. Sci. (Forthcoming). 
Koch J, Mettler S (2012) Who perceives government's role in their lives? Assessing the impact of social policy on visibility (Ithaca, NY).

Kraft T, Valdés L, Zheng Y (2018) Supply chain visibility and social responsibility : Investigating consumers ' behaviors and motives. Manuf. Serv. Oper. Manag. 20(4):617-636.

Kruger J, Wirtz D, Van Boven L, Altermatt TW (2004) The effort heuristic. J. Exp. Soc. Psychol. 40(1):91-98.

Lewis-Beck ML, Jacoby WG, Norpoth H, Weisberg HF (2008) The American Voter Revisited (University of Michigan Press, Ann Arbor, MI).

Linnenbrink E a, Pintrich PR (2003) The role of self-efficacy belief in student engagement and learning in the classroom. Read. Writ. $Q$.

Mejia J, Parker C (2018) When transparency fails: Bias and financial incentives in ridesharing platforms. SSRN.

Mejia J, Urrea G, Pedraza-Martinez AJ (2019) Operational transparency on crowdfunding platforms: Effect on donations for emergency response. Prod. Oper. Manag. 28(7):1773-1791.

Mettler S (2011) The Submerged State: How Invisible Government Policies Undermine American Democracy (University of Chicago Press, Chicago).

Miller AH (1974) Political issues and trust in government: 1964-1970. Am. Polit. Sci. Rev. 68(03):951972.

Mohan B, Buell RW, John LK (2019) Lifting the veil: The benefits of cost transparency. Mark. Sci. Forthcomin:36.

Mohr LA, Bitner MJ (1995) The role of employee effort in satisfaction with service transactions. J. Bus. Res. 32(3):239-252.

Morales AC (2005) Giving firms an E for effort: Consumer responses to high-effort firms. J. Consum. Res. 31(4):806-812.

Neely A, Mcfarlane D, Visnjic I (2011) Complex service systems - Identifying drivers, characteristics and success factors. 18th Int. Annu. EurOMA Conf. Explor. Interfaces. (Cambridge University Press, Cambridge, UK), 74.

Özer Ö, Subramanian U, Wang Y (2018) Information sharing, advice provision, or delegation: What leads to higher trust and trustworthiness? Manage. Sci.

Özer Ö, Zheng Y (2016) Establishing trust and trustworthiness for supply chain information sharing. Ha A, Tang C, eds. Handb. Inf. Exch. Supply Chain Manag. (Springer).

Özer Ö, Zheng Y (2019) Trust and trustworthiness. Handb. Behav. Oper.

Parasuraman A, Zeithaml VA, Berry LL (1985) A conceptual model of service quality and its implications for future research. J. Mark. 49(4):41-50.

Pew Research Center (2019) Public trust in government: 1958-2019 
Pierson P (1993) When effect becomes cause: Policy feedback and political change. World Polit. 45(4):595-628.

Putnam RD (2000) Bowling Alone: The Collapse and Revival of American Community (Simon and Schuster, New York, NY).

Robertson D, Keller C (1992) Relationships among health beliefs, self-efficacy, and exercise adherence in patients with coronary artery disease. Hear. Lung J. Crit. Care.

Roels G (2014) Optimal design of coproductive services: Interaction and work allocation. Manuf. Serv. Oper. Manag. 16(4):578-594.

Rosenstone SJ, Hansen M (1993) Mobilization, Participation and Democracy in America (Pearson).

Rule NO, Ambady N (2008) The face of success: inferences from chief executive officers' appearance predict company profits. Psychol. Sci. 19:109-111.

Sampson SE, Froehle CM (2006) Foundations and implications of a proposed unified services theory. Prod. Oper. Manag. 15(2):329-343.

Schlozman KL, Verba S, Brady HE (2012) The unheavenly chorus: Unequal political voice and the broken promise of American democracy

Simmons JP, Nelson LD, Simonsohn U (2012) A 21-word solution. SPSP Dialogue:1-4.

Skocpol T (2003) Diminished Democracy: From Membership to Management in American Civic Life (University of Oklahoma Press, Norman, OK).

Staats BR, Dai H, Hoffmann DA, Milkman KL (2016) Process compliance and electronic monitoring: Empirical evidence from hand hygiene in healthcare. Manage. Sci. 63(5):1563-1585.

Tsay CJ (2014) The vision heuristic: Judging music ensembles by sight alone. Organ. Behav. Hum. Decis. Process. 124(1):24-33.

U.S. Bureau of Labor Statistics (2019) All employees, thousands, government, not seasonally adjusted (Washington, D.C.).

Zrinyi M, Juhasz M, Balla J, Katona E, Ben T, Kakuk G, Pall D (2003) Dietary self-efficacy: Determinant of compliance behaviours and biochemical outcomes in haemodialysis patients. Nephrol. Dial.

Transplant. 


\section{Online Appendix for "Surfacing the Submerged State: Operational Transparency Increases Trust in and Engagement with Government"}

1. Study 1: Full sample analysis and supplemental exhibits

\begin{tabular}{lcc}
\hline Request & Count & Percentage \\
\hline Illegal graffiti & 17,633 & $11.76 \%$ \\
Unshoveled sidewalk & 10,315 & $6.88 \%$ \\
Street lights & 9,985 & $6.66 \%$ \\
Pothole & 8,515 & $5.68 \%$ \\
Litter & 7,793 & $5.20 \%$ \\
Snow and ice control & 7,424 & $4.95 \%$ \\
Broken sidewalk & 4,907 & $3.27 \%$ \\
Damaged sign & 4,014 & $2.68 \%$ \\
Overflowing trash can & 2,853 & $1.90 \%$ \\
Illegal parking & 2,800 & $1.87 \%$ \\
Student move-in issues & 972 & $0.65 \%$ \\
Missed trash or recycling & 494 & $0.33 \%$ \\
Dead animal pick-up & 493 & $0.33 \%$ \\
Traffic signal & 480 & $0.32 \%$ \\
Dead tree removal & 423 & $0.28 \%$ \\
Tree pruning & 325 & $0.22 \%$ \\
Needle clean-up & 230 & $0.15 \%$ \\
Rodent sighting & 223 & $0.15 \%$ \\
Broken park equipment & 216 & $0.14 \%$ \\
Abandoned vehicle & 205 & $0.14 \%$ \\
Abandoned bicycle & 134 & $0.09 \%$ \\
Park lights & 65 & $0.04 \%$ \\
Other & 69,452 & $46.32 \%$ \\
\hline Total Requests & & $100.00 \%$ \\
\hline
\end{tabular}

Table A1: Breakdown of Service Requests. Data represents requests submitted to the City of Boston through the Citizen's Connect application between September 10, 2009 and October 27, 2015.

As described in the exposition of the manuscript, we conducted our primary analyses for Study 3 on a sub-sample of the data $(N=21,786)$ that excluded users who submitted 21 or more requests in a given month (the top percentile), in part because it was possible that such heavy users were government employees. We note that all results are substantively similar when all observations are included $(N=$ 21,986). Tables A2 and A3 provide comparisons of the results in the full and focal samples. 


\begin{tabular}{|c|c|c|c|c|c|c|}
\hline & (1) & $(2)$ & (3) & (4) & $(5)$ & (6) \\
\hline & $\begin{array}{l}\text { Monthly } \\
\text { Count }\end{array}$ & $\begin{array}{l}\text { Monthly } \\
\text { Count }\end{array}$ & $\begin{array}{l}\text { Monthly } \\
\text { Count }\end{array}$ & $\begin{array}{l}\text { Category } \\
\text { Count }\end{array}$ & $\begin{array}{l}\text { Category } \\
\text { Count }\end{array}$ & $\begin{array}{l}\text { Category } \\
\text { Count }\end{array}$ \\
\hline Transparency & $\begin{array}{c}0.667^{\star \star *} \\
(0.184)\end{array}$ & $\begin{array}{c}0.130 \\
(0.134)\end{array}$ & $\begin{array}{c}-6.890^{\star \star \star} \\
(1.761)\end{array}$ & $\begin{array}{c}0.316^{\star \star \star} \\
(0.059)\end{array}$ & $\begin{array}{c}0.041 \\
(0.046)\end{array}$ & $\begin{array}{c}-2.990^{\star \star \star} \\
(0.562)\end{array}$ \\
\hline First transparency month indicator & & $\begin{array}{c}2.452^{\star \star \star} \\
(0.173)\end{array}$ & $\begin{array}{c}2.488^{\star \star \star} \\
(0.214)\end{array}$ & & $\begin{array}{l}1.255^{\star \star \star} \\
(0.041)\end{array}$ & $\begin{array}{l}1.271^{\star \star \star} \\
(0.049)\end{array}$ \\
\hline Percentage of requests closed & & & $\begin{array}{l}1.220^{\star \star \star} \\
(0.189)\end{array}$ & & & $\begin{array}{l}1.043^{\star \star \star} \\
(0.068)\end{array}$ \\
\hline Percentage of requests closed ${ }^{2}$ & & & $\begin{array}{c}-0.919^{\star \star \star} \\
(0.171)\end{array}$ & & & $\begin{array}{c}-0.910^{* * *} \\
(0.070)\end{array}$ \\
\hline Transparency x Percentage closed & & & $\begin{array}{c}17.650^{\star \star \star} \\
(5.027)\end{array}$ & & & $\begin{array}{l}7.662^{\star \star \star} \\
(1.494)\end{array}$ \\
\hline Transparency x Percentage closed $^{2}$ & & & $\begin{array}{c}-10.766^{\star \star *} \\
(3.315)\end{array}$ & & & $\begin{array}{c}-4.698^{\star \star \star} \\
(0.958)\end{array}$ \\
\hline Tenure & $\begin{array}{c}-0.034^{\star \star \star} \\
(0.003)\end{array}$ & $\begin{array}{c}-0.031^{\star \star \star} \\
(0.002)\end{array}$ & $\begin{array}{c}-0.032^{\star \star \star} \\
(0.002)\end{array}$ & $\begin{array}{c}-0.022^{\star * *} \\
(0.001)\end{array}$ & $\begin{array}{c}-0.021^{\star * *} \\
(0.001)\end{array}$ & $\begin{array}{c}-0.021^{\star * *} \\
(0.001)\end{array}$ \\
\hline Tenure $^{2}$ & $\begin{array}{l}0.000^{\star \star *} \\
(0.000)\end{array}$ & $\begin{array}{l}0.000^{\star \star \star} \\
(0.000)\end{array}$ & $\begin{array}{l}0.000^{\star * *} \\
(0.000)\end{array}$ & $\begin{array}{l}0.000^{\star * *} \\
(0.000)\end{array}$ & $\begin{array}{l}0.000^{\star \star \star} \\
(0.000)\end{array}$ & $\begin{array}{c}0.000^{\star \star \star} \\
(0.000)\end{array}$ \\
\hline Total number of closed submissions & $\begin{array}{r}-0.006 \\
(0.017)\end{array}$ & $\begin{array}{l}-0.004 \\
(0.011)\end{array}$ & $\begin{array}{c}-0.004 \\
(0.013)\end{array}$ & $\begin{array}{l}-0.006 \\
(0.004)\end{array}$ & $\begin{array}{l}-0.005^{*} \\
(0.003)\end{array}$ & $\begin{array}{c}-0.006^{\star *} \\
(0.003)\end{array}$ \\
\hline Constant & $\begin{array}{l}0.694^{\star \star \star} \\
(0.049)\end{array}$ & $\begin{array}{l}0.662^{\star \star \star} \\
(0.044)\end{array}$ & $\begin{array}{l}0.377^{\star \star \star} \\
(0.058)\end{array}$ & $\begin{array}{l}0.458^{\star \star \star} \\
(0.016)\end{array}$ & $\begin{array}{l}0.441^{\star \star *} \\
(0.011)\end{array}$ & $\begin{array}{c}0.300^{* * *} \\
(0.032)\end{array}$ \\
\hline $\begin{array}{l}\text { Observations } \\
\text { R-squared } \\
\text { Number of reporters }\end{array}$ & $\begin{array}{c}375,889 \\
0.010 \\
21,986\end{array}$ & $\begin{array}{c}375,889 \\
0.022 \\
21,986\end{array}$ & $\begin{array}{c}375,889 \\
0.023 \\
21,986\end{array}$ & $\begin{array}{c}375,889 \\
0.037 \\
21,986\end{array}$ & $\begin{array}{c}375,889 \\
0.066 \\
21,986\end{array}$ & $\begin{array}{c}375,889 \\
0.068 \\
21,986\end{array}$ \\
\hline
\end{tabular}

Table A2: Operational transparency increases resident engagement $(N=375,889$ monthly observations from 21,986 resident reporters) (Study 1). Residents submit more service requests, and across a broader array of categories after observing operational transparency, though the effects are attenuated relative to the focal sub-sample, which withholds high-intensity submitters. $* * *$, and $* * *$ signify significance at the $10 \%, 5 \%$ and $1 \%$ levels, respectively, relative to the blind treatment.

\section{Study 2: Question battery and factor analysis}

To measure participants' trust in and support for government, we relied upon the Pew Center for the People and the Press Trust in Government Survey (Dimock et al. 2013). This 14-question battery, the full text of which appears in Table A4, measures participants' attitudes about government's role in their everyday lives, government's role as being positive or negative, the quality of civil service, and whether they trust government to do what is right, as well as whether they would prefer a bigger or smaller government with more or fewer services, and whether government programs should be maintained or cut back. Responses were standardized and an exploratory factor analysis was conducted, which revealed eight questions that measured participants' trust in government $(\alpha=0.87)$, and two questions that measured support for government programs $(\alpha=0.77)$. The same battery and factor analysis approach was used in the Appendix Study, which is described in Section 4 of the online appendix. 


\begin{tabular}{|c|c|c|c|c|}
\hline & (1) & (2) & (3) & (4) \\
\hline & $\begin{array}{l}\text { Monthly } \\
\text { Count }\end{array}$ & $\begin{array}{c}\text { Category } \\
\text { Count }\end{array}$ & $\begin{array}{c}\text { Monthly } \\
\text { Count }\end{array}$ & $\begin{array}{c}\text { Category } \\
\text { Count }\end{array}$ \\
\hline 1 month after exposure & $\begin{array}{l}0.990^{\star * *} \\
(0.068)\end{array}$ & $\begin{array}{l}0.461^{* * *} \\
(0.032)\end{array}$ & $\begin{array}{l}1.526^{\star * *} \\
(0.168)\end{array}$ & $\begin{array}{c}0.523^{\star \star *} \\
(0.038)\end{array}$ \\
\hline 2 months after exposure & $\begin{array}{l}0.472^{\star * *} \\
(0.062)\end{array}$ & $\begin{array}{l}0.190^{* * *} \\
(0.026)\end{array}$ & $\begin{array}{l}0.489^{* * *} \\
(0.145)\end{array}$ & $\begin{array}{l}0.182^{\star \star \star} \\
(0.034)\end{array}$ \\
\hline 3 months after exposure & $\begin{array}{c}0.394^{\star * *} \\
(0.057)\end{array}$ & $\begin{array}{l}0.152^{* * *} \\
(0.031)\end{array}$ & $\begin{array}{l}0.263^{*} \\
(0.140)\end{array}$ & $\begin{array}{l}0.102^{\star \star \star} \\
(0.030)\end{array}$ \\
\hline 4 months after exposure & $\begin{array}{l}0.418^{* * *} \\
(0.071)\end{array}$ & $\begin{array}{l}0.161^{\star \star \star} \\
(0.031)\end{array}$ & $\begin{array}{l}0.273^{*} \\
(0.151)\end{array}$ & $\begin{array}{l}0.081^{* *} \\
(0.031)\end{array}$ \\
\hline 5 months after exposure & $\begin{array}{l}0.389^{* * *} \\
(0.072)\end{array}$ & $\begin{array}{l}0.166^{\star \star \star} \\
(0.027)\end{array}$ & $\begin{array}{c}0.002 \\
(0.181)\end{array}$ & $\begin{array}{c}0.028 \\
(0.041)\end{array}$ \\
\hline 6 months after exposure & $\begin{array}{c}0.456^{\star * *} \\
(0.069)\end{array}$ & $\begin{array}{c}0.170^{* * *} \\
(0.034)\end{array}$ & $\begin{array}{c}0.095 \\
(0.168)\end{array}$ & $\begin{array}{l}0.083^{*} \\
(0.044)\end{array}$ \\
\hline 7 months after exposure & $\begin{array}{c}0.529^{* * *} \\
(0.091)\end{array}$ & $\begin{array}{l}0.192^{* \star *} \\
(0.037)\end{array}$ & $\begin{array}{l}0.535^{\star * *} \\
(0.200)\end{array}$ & $\begin{array}{l}0.138^{\star *} \\
(0.065)\end{array}$ \\
\hline 8 months after exposure & $\begin{array}{c}0.399^{* * *} \\
(0.083)\end{array}$ & $\begin{array}{c}0.147^{\star * *} \\
(0.030)\end{array}$ & $\begin{array}{c}0.399 \\
(0.305)\end{array}$ & $\begin{array}{c}0.080 \\
(0.051)\end{array}$ \\
\hline 9 months after exposure & $\begin{array}{l}0.451^{* * *} \\
(0.091)\end{array}$ & $\begin{array}{l}0.141^{* * *} \\
(0.040)\end{array}$ & $\begin{array}{c}0.286 \\
(0.252)\end{array}$ & $\begin{array}{c}0.013 \\
(0.074)\end{array}$ \\
\hline 10 months after exposure & $\begin{array}{c}0.455^{\star * *} \\
(0.108)\end{array}$ & $\begin{array}{c}0.162^{\star * *} \\
(0.039)\end{array}$ & $\begin{array}{c}0.334 \\
(0.631)\end{array}$ & $\begin{array}{l}-0.062 \\
(0.097)\end{array}$ \\
\hline 11 months after exposure & $\begin{array}{c}0.425^{\star * *} \\
(0.093)\end{array}$ & $\begin{array}{c}0.138^{* * *} \\
(0.041)\end{array}$ & $\begin{array}{l}-0.543 \\
(0.524)\end{array}$ & $\begin{array}{r}-0.086 \\
(0.119)\end{array}$ \\
\hline 12 months after exposure & $\begin{array}{c}0.120 \\
(0.100)\end{array}$ & $\begin{array}{c}0.022 \\
(0.039)\end{array}$ & $\begin{array}{l}-1.372^{*} \\
(0.702)\end{array}$ & $\begin{array}{l}-0.310^{*} \\
(0.174)\end{array}$ \\
\hline 13 months after exposure & $\begin{array}{c}0.108 \\
(0.116)\end{array}$ & $\begin{array}{c}0.004 \\
(0.052)\end{array}$ & $\begin{array}{l}-2.322^{\star \star} \\
(1.133)\end{array}$ & $\begin{array}{l}-0.330 \\
(0.278)\end{array}$ \\
\hline 14 months after exposure & $\begin{array}{c}0.332 \\
(0.708)\end{array}$ & $\begin{array}{c}0.396 \\
(0.391)\end{array}$ & $\begin{array}{l}-7.542 \\
(5.282)\end{array}$ & $\begin{array}{l}-1.270 \\
(0.917)\end{array}$ \\
\hline Constant & $\begin{array}{c}0.171^{* * *} \\
(0.014)\end{array}$ & $\begin{array}{l}0.060^{\star * *} \\
(0.006)\end{array}$ & $\begin{array}{c}0.038 \\
(0.031)\end{array}$ & $\begin{array}{l}0.028^{* * *} \\
(0.008)\end{array}$ \\
\hline Observations & 371,992 & 371,992 & 375,889 & 375,889 \\
\hline R-squared & 0.425 & 0.645 & 0.134 & 0.511 \\
\hline Number of reporters & 21,786 & 21,786 & 21,986 & 21,986 \\
\hline Sample & $\begin{array}{c}\text { Withholding } \\
\text { high-intensity } \\
\text { submitters }\end{array}$ & $\begin{array}{l}\text { Withholding } \\
\text { high-intensity } \\
\text { submitters }\end{array}$ & Full sample & Full sample \\
\hline
\end{tabular}

Table A3: Persistence of the effects of operational transparency on citizen engagement for the focal subsample $(N=21,786)$ and full sample of residents $(N=21,986)$ (Study 1$)$. The effects of operational transparency on the count of monthly submissions and the number of categories into which users submit requests persists in the months following exposure to the treatment. $*, * *$, and $* * *$ signify significance at the $10 \%, 5 \%$ and $1 \%$ levels, respectively, relative to the control. 


\begin{tabular}{|c|c|c|c|c|c|}
\hline & & \multicolumn{2}{|c|}{ Study 2} & \multicolumn{2}{|c|}{ Appendix Study } \\
\hline & & $\begin{array}{l}\text { Composite } \\
\text { Trust Factor } \\
\text { Loadings }\end{array}$ & $\begin{array}{l}\text { Composite } \\
\text { Support Factor } \\
\text { Loadings }\end{array}$ & $\begin{array}{l}\text { Composite } \\
\text { Trust Factor } \\
\text { Loadings }\end{array}$ & $\begin{array}{l}\text { Composite } \\
\text { Support Factor } \\
\text { Loadings }\end{array}$ \\
\hline 1 & $\begin{array}{l}\text { All in all, how well or how badly do you think the system of } \\
\text { democracy in this country works these days? } \\
\text { ( } 1 \text { works well - } 3 \text { does not work well) }\end{array}$ & 0.577 & -0.304 & 0.572 & -0.269 \\
\hline 2 & $\begin{array}{l}\text { Most civil servants can be trusted to do what is best for the } \\
\text { country. } \\
\text { (1=strongly agree }-5 \text { strongly disagree) }\end{array}$ & 0.656 & -0.225 & 0.722 & 0.145 \\
\hline 3 & $\begin{array}{l}\text { People like me don't have any say about what the } \\
\text { government does. } \\
\text { (1=strongly agree }-6 \text { strongly disagree) }\end{array}$ & 0.327 & -0.001 & 0.571 & -0.016 \\
\hline 4 & $\begin{array}{l}\text { Elections are a good way of making the government pay } \\
\text { attention to the important political issues facing our country. } \\
(1=\text { strongly agree }-5 \text { strongly disagree })\end{array}$ & 0.504 & 0.059 & 0.635 & 0.072 \\
\hline 5 & $\begin{array}{l}\text { All in all, would you say the government is having a } \\
\text { positive or negative effect on the way things are going in } \\
\text { this country today? } \\
\text { (1=negative, } 2=\text { positive) }\end{array}$ & 0.608 & -0.049 & 0.655 & -0.256 \\
\hline 6 & $\begin{array}{l}\text { Which would you rather have? } \\
\text { (Bigger government, more services / Smaller government, fewer } \\
\text { services) }\end{array}$ & 0.416 & 0.667 & 0.149 & 0.887 \\
\hline 7 & $\begin{array}{l}\text { Overall, would you say the agencies and departments of the } \\
\text { government are doing an excellent, good, only fair, or a } \\
\text { poor job? } \\
(1=\text { excellent }-5=\text { poor })\end{array}$ & 0.711 & 0.006 & 0.759 & -0.023 \\
\hline 8 & $\begin{array}{l}\text { How much of the time do you think you can trust the } \\
\text { government to do what is right? } \\
\text { (1=just about always - } 4=\text { never) }\end{array}$ & 0.695 & -0.091 & 0.806 & -0.029 \\
\hline 9 & $\begin{array}{l}\text { Which comes closer to your view? } \\
\text { ( } 1=\text { Criticism of government is often justified/ } 2 \text { = Government } \\
\text { often does better job than given credit for) }\end{array}$ & 0.608 & 0.129 & 0.581 & 0.066 \\
\hline & $\begin{array}{l}\text { Where on the following scale of } 1 \text { to } 6 \text { would you place } \\
\text { yourself? } \\
\text { (1=Government programs should be cut back/ } 6 \text { = Government } \\
\text { programs should be maintaned) }\end{array}$ & 0.359 & 0.788 & 0.204 & 0.875 \\
\hline 11 & $\begin{array}{l}\text { How much effect do you think the government's activities - } \\
\text { the laws passed and so on - have on your day-to-day life? } \\
(1=\text { Great effect }-3=\text { No effect) }\end{array}$ & 0.273 & 0.462 & -0.009 & 0.183 \\
\hline & $\begin{array}{l}\text { In general, is the government's effect on your life positive or } \\
\text { negative? } \\
(1=\text { Positive/ } 2=\text { Negative })\end{array}$ & 0.595 & -0.084 & 0.727 & 0.083 \\
\hline & $\begin{array}{l}\text { Some people say they are basically content with the } \\
\text { government, others say they are frustrated, and others say } \\
\text { they are angry. Which of these best describes how you } \\
\text { feel? } \\
\text { (1=Content, } 2=\text { Frustrated, } 3=\text { Angry) }\end{array}$ & 0.655 & -0.284 & 0.707 & -0.205 \\
\hline & $\begin{array}{l}\text { Do you think the government threatens your own personal } \\
\text { rights and freedoms, or not? } \\
(1=\mathrm{No}, 2=\mathrm{Yes})\end{array}$ & 0.576 & -0.255 & 0.648 & -0.063 \\
\hline & $\begin{array}{l}\text { Eigenvalue } \\
\text { Chronbach's Alpha }\end{array}$ & $\begin{array}{l}4.342 \\
0.831\end{array}$ & $\begin{array}{l}1.606 \\
0.739\end{array}$ & $\begin{array}{l}5.082 \\
0.878\end{array}$ & $\begin{array}{l}1.808 \\
0.826\end{array}$ \\
\hline
\end{tabular}

Table A4: Factor loadings for the Composite Trust and Support measures (Study 2 and Appendix Study). A factor loading cutoff of 0.55 was used to identify items from the Pew Center for the People and the Press Trust in Government Survey (Dimock et al. 2013) that were included in the Composite Trust and Composite Support measures for Study 2 and the Appendix Study. This approach resulted in nine trust items $(\alpha=0.83)$ and two support items $(\alpha=0.74)$ in Study 2 and eleven trust items $(\alpha=0.88)$ and two support items $(\alpha=0.83)$ in the Appendix Study. Factor loadings that exceeded the cutoff are displayed in bold in the table above. 


\section{Study 3: Question battery and supplemental exhibits}

Below are the questions used in Study 3. The italicized question labels map to the item labels in Figure 7, and summary statistics are provided in Table $\mathbf{A 5}$.

\begin{tabular}{|c|c|c|c|c|c|c|c|c|c|c|c|c|}
\hline & \multicolumn{4}{|c|}{$60 \%$ responsiveness $(n=461)$} & \multicolumn{4}{|c|}{$80 \%$ responsiveness $(n=461)$} & \multicolumn{4}{|c|}{$100 \%$ responsiveness $(n=448)$} \\
\hline & \multicolumn{2}{|c|}{ Non-transparent } & \multicolumn{2}{|c|}{ Transparent } & \multicolumn{2}{|c|}{ Non-transparent } & \multicolumn{2}{|c|}{ Transparent } & \multicolumn{2}{|c|}{ Non-transparent } & \multicolumn{2}{|c|}{ Transparent } \\
\hline & Mean & SD & Mean & SD & Mean & SD & Mean & $\mathrm{SD}$ & Mean & SD & Mean & SD \\
\hline Efficacy & 4.72 & 1.32 & 4.67 & 1.37 & 5.50 & 1.19 & 5.40 & 1.18 & 5.69 & 1.46 & 5.69 & 1.41 \\
\hline Perceived effort & 5.56 & 1.03 & 5.72 & 1.02 & 5.65 & 1.15 & 5.82 & 0.93 & 5.82 & 1.16 & 6.09 & 0.96 \\
\hline Appreciation & 5.58 & 1.28 & 5.84 & 1.18 & 5.79 & 1.40 & 5.98 & 1.13 & 5.81 & 1.37 & 6.21 & 1.04 \\
\hline Trust & 5.22 & 1.11 & 5.31 & 1.08 & 5.36 & 1.25 & 5.48 & 1.03 & 5.54 & 1.24 & 5.77 & 1.04 \\
\hline Support & 5.12 & 1.27 & 5.13 & 1.29 & 5.13 & 1.37 & 5.15 & 1.44 & 5.03 & 1.29 & 5.20 & 1.27 \\
\hline Perceived impact & 5.36 & 1.18 & 5.52 & 1.12 & 5.44 & 1.26 & 5.60 & 1.07 & 5.41 & 1.24 & 5.82 & 1.02 \\
\hline Positivity toward self & 5.70 & 1.31 & 5.86 & 1.20 & 5.72 & 1.46 & 5.89 & 1.27 & 5.84 & 1.36 & 6.15 & 1.13 \\
\hline Willingness to engage & 6.20 & 1.09 & 6.19 & 1.05 & 6.17 & 1.25 & 6.36 & 1.09 & 6.23 & 1.21 & 6.45 & 0.93 \\
\hline Percentage female & 0.48 & 0.50 & 0.47 & 0.50 & 0.51 & 0.50 & 0.55 & 0.50 & 0.40 & 0.49 & 0.50 & 0.50 \\
\hline Average age & 37.53 & 11.81 & 38.23 & 11.97 & 39.58 & 28.04 & 38.66 & 12.22 & 37.81 & 11.32 & 37.07 & 11.04 \\
\hline Education level & 3.29 & 1.29 & 3.29 & 1.31 & 3.34 & 1.29 & 3.16 & 1.35 & 3.27 & 1.24 & 3.30 & 1.23 \\
\hline Income level & 7.13 & 1.95 & 7.21 & 2.00 & 7.16 & 2.13 & 7.10 & 2.04 & 7.30 & 1.95 & 7.24 & 1.93 \\
\hline Conservatism & 3.47 & 2.17 & 3.31 & 2.07 & 3.46 & 2.14 & 3.53 & 2.15 & 3.47 & 2.06 & 3.38 & 2.09 \\
\hline Political interest & 3.74 & 1.02 & 3.73 & 1.05 & 3.75 & 1.12 & 3.80 & 1.07 & 3.78 & 0.98 & 3.74 & 1.10 \\
\hline Political knowledge & 3.56 & 0.87 & 3.61 & 0.95 & 3.61 & 0.99 & 3.57 & 0.87 & 3.73 & 0.88 & 3.62 & 0.93 \\
\hline Political ideology & 2.51 & 1.35 & 2.63 & 1.41 & 2.55 & 1.39 & 2.56 & 1.34 & 2.69 & 1.38 & 2.51 & 1.31 \\
\hline Learning & 5.39 & 1.43 & 5.65 & 1.30 & 5.50 & 1.42 & 5.65 & 1.33 & 5.55 & 1.38 & 5.79 & 1.27 \\
\hline Graphical appeal & 5.35 & 1.20 & 5.55 & 1.08 & 5.41 & 1.21 & 5.49 & 1.14 & 5.56 & 0.99 & 5.68 & 1.05 \\
\hline
\end{tabular}

Table A5: Summary statistics (Study 3).

Based on the scenario above, please rate the extent to which you disagree or agree with the following statements? ( $1=$ strongly disagree $-7=$ strongly agree $)$

- Care: Officials in the Boston local government don't care much what people like me think.

- Clarity: Sometimes operations in the Boston local government seem so complicated that a person like me can't really understand what's going on.

- Say: People like me don't have any say in what gets done by the Boston local government.

Recalling the scenario above, please select the answers below that best align with your perspective. ( $1=$ None/not at all $-7=$ A great amount/very)

- Effort: How much effort do you think the Boston local government exerts on behalf of its citizens?

- Expertise: How much expertise do you think the Boston local government has?

- Experience: How much experience does the Boston local government have?

- Thorough: How thorough is the Boston local government in addressing citizens' needs?

- Positivity: How positive do you feel toward the Boston local government?

- Gratitude: How grateful do you feel toward the Boston local government?

- Appreciate: How grateful do you feel toward the Boston local government? 
- Depend: To what extent does solving this problem depend on your success or failure in engaging with the Boston local government?

- Methods Impact: To what extent do the methods that you use to engage with the Boston local government have an impact on solving this problem?

- Perform Impact: To what extent does your level of performance in engaging with the Boston local government have an impact on solving this problem?

- Positivity Toward Self: How positive do you feel toward yourself for engaging with the Boston government to solve this problem?

Recalling the scenario above, please rate the extent to which you disagree or agree with the following statements. ( $1=$ Strongly disagree $-7=$ Strongly agree).

- Trust: I can trust the Boston local government.

- Rely: I can rely on the Boston local government.

- Honest: The Boston local government is honest.

Which would you rather have? (1=Smaller Boston local government with fewer services $-7=$ Bigger Boston local government with more services)

Where on the following scale would you place yourself? ( 1 =Boston local government programs should be cut back $-7=$ Boston local government programs should be expanded)

If you were given the opportunity, how likely would you be to use the Citizen's Connect app in the future? ( 1 =Extremely unlikely $=7=$ Extremely likely)

During the scenario described above, what kind of service request were you asked to imagine submitting to the Boston local government? (1=Illegal graffiti, 2=Unshoveled sidewalk, 3=Broken streetlight, 4=Damaged sign, $5=$ Dead animal removal, $6=$ Trash/litter)

To what extent did you learn new things about what the Boston local government does from the scenario described above? $(1=$ Not at all $=7=$ To a great extent $)$

Please indicate the extent to which you disagree or agree with the following statements about the Citizen's Connect app used by the Boston local government in the scenario above. ( $1=$ Strongly disagree $-7=$ Strongly agree)

- Graphics 1: I liked the graphics and images I saw in the app.

- Graphics 2: The screen layout of the app was visually pleasing.

- Graphics 3: The app was attractive.

- Graphics 4: The app appealed to my visual senses.

- Graphics 5: The app was aesthetically appealing.

Are you male or female? (1=Male, $2=$ Female)

What is your age? (in years)

Please select the highest level of education you have completed. ( $1=$ High school, $2=$ Some college, $3=$ Associate's degree (2-year college), 4=Bachelor's degree (4-year college), 5=Master's degree, 6=Doctorate or professional degree, $7=$ Other)

What is your MONTHLY HOUSEHOLD income? Please include income from wages and tips, remittances from family members living elsewhere, and all other sources. (Do not include the salaries of roommates or 
others living with you but not sharing finances.) ( $1=$ None, $2=$ Under $\$ 60,3=\$ 60-499,4=\$ 500-999,5=\$ 1,000-1,999$, $6=\$ 2,000-2,999,7=\$ 3,000-3,999,8=\$ 4,000-\$ 4,999,9=\$ 5,000-7,499,10=\$ 7,500-\$ 9,999,11=$ Over $\$ 10,000$.

Generally speaking, do you usually think of yourself as a Republican, Democrat, Independent, or what? ( $1=$ Strong democrat, $2=$ Not very strong democrat, $3=$ =Independent, close to democrat, $4=$ =Independent, $5=$ =Independent, close to republican, $6=$ Not very strong republican, $7=$ Strong republican, $8=$ Other party)

How interested would you say you personally are in politics? ( $1=$ Very interested $-7=$ Not at all interested)

How knowledgeable are you about political issues? $(1=$ Very knowledgeable $-7=$ Not at all knowledgeable $)$

When it comes to politics, do you usually think of yourself as: $(1=$ Liberal, $2=$ Slightly liberal, $3=$ Moderate or middle of the road, $4=$ Slightly conservative, $5=$ Conservative)

\section{Appendix Study 1: Defining operational transparency}

4.1.1. Design: The results presented throughout the manuscript suggest that elevating the submerged state by increasing operational transparency can affect peoples' attitudes toward government. In this study, we tighten our conceptualization of operational transparency by exploring which types of revelations engender increased trust in and support for government. In particular, we test whether showing the work government does impacts attitudes above and beyond merely telling people about the work, and which specific pieces of information are most influential to convey.

We conducted this study using the template and data from the Boston 311 (BOS:311) website. BOS:311 (currently online at https://311.boston.gov) provides a real time view of the public service requests that are submitted to Boston's government and the work that city employees do in responding to each request. When a new request is submitted, the website shows the textual description of the request, the location on a map of where work is to be performed, and if provided, the photo submitted by the requester of the work that needs to be done. When the work is completed, the website appends a blue "closed" tag to the request, as well as the textual description provided by the city worker of the action that was performed, and, if provided, a photo of the work that was done.

We randomly selected 50 service requests that were submitted and fulfilled in Boston in October 2015, for which textual descriptions and decipherable photos were provided by citizens when the request was submitted, and by city workers when the work was completed. Using the data from each completed request, we created five versions of the BOS:311 website (Figure A1), which revealed different elements of each service request and of the work that was performed. In a baseline condition, participants saw the title of each request, as well as the textual description of the issue, as described by the citizen who reported it, in addition to the textual description of the resolution, as described by the employee who addressed it. This textual information was included in every experimental condition. A second condition additionally included 
a map, pinpointing the exact location of the service request. A third condition additionally included a photo of the issue that was submitted by the citizen when they opened the request. A fourth condition instead included a photo of the resolution, submitted by the city employee when they closed the request. Finally, a fifth condition provided all of the elements described above - which corresponds with all of the information provided on the BOS:311 website. By varying the elements presented in each condition, we are able to better identify which elements are responsible for improving attitudes toward government.

We recruited 500 voting-age participants on the Amazon Mechanical Turk platform (48.0\% female, $M_{\text {age }}=39.5$ ) to complete a ten-minute survey in exchange for $\$ 1.00$. After completing the informed consent process, and reading introductory text about service requests in the City of Boston, participants were provided links to three randomly-selected service requests (from among the catalog of 50 service requests described above) and were instructed to review each request before answering a series of questions. The linked service requests were presented in accordance with each participant's randomly assigned experimental condition. After reviewing the three service requests, drawing on Study 2, participants were asked to answer questions about their attitudes toward and levels of trust in government spending - "Do you favor increases in the taxes paid by ordinary Americans in order to increase spending on domestic programs like Medicare, education, and highways?" and "Do you think that people in the government waste a lot of money we pay in taxes, waste some of it, or don't waste very much of it?" (Hansen 1998, The American National Election Studies 2016), as well as questions from the Pew Center for the People and the Press Trust in Government survey (Dimock et al. 2013).

As in Study 2, we additionally asked participants' age, gender, education level, race, household income, party identification, and political ideology, as well as an attention check question, "Debates about television shows are a pastime of American life. Everyone has a different favorite show. We want to know if you are paying attention to this survey. To show you are paying attention, ignore the question below and choose both The Sopranos and Saturday Night Live." Furthermore, we asked participants whether they were able to see the linked service request web pages, and we monitored the total amount of time that participants spent interacting with the service requests and the survey. 29 participants failed to access the three service request webpages assigned to them. An additional 4 participants reported not being able to view the webpages, 6 participants failed the attention check question, and 29 participants were detected to reside outside the United States, resulting in a final sample of 432 participants $\left(50.7 \%\right.$ female, $\left.M_{\text {age }}=39.5\right)$. As in Studies 1 and 2, responses to the Pew questions were standardized and a factor analysis was conducted, which yielded an eleven-item trust measure $(\alpha=0.88)$ and a two-item support measure $(\alpha=0.83)$ with high scale reliability coefficients (Table A4). 


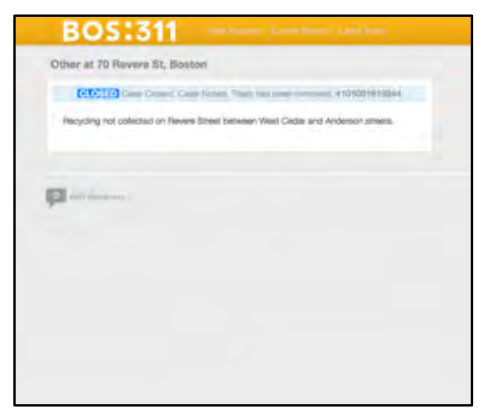

1. Text Only

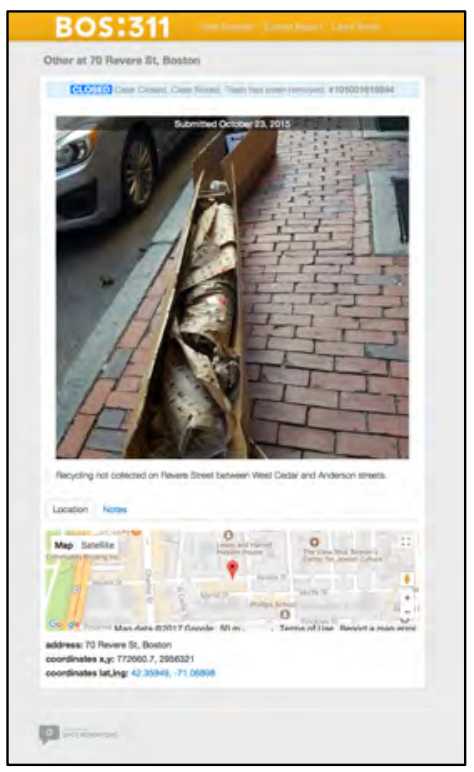

3. Text, Map, and Open Photo

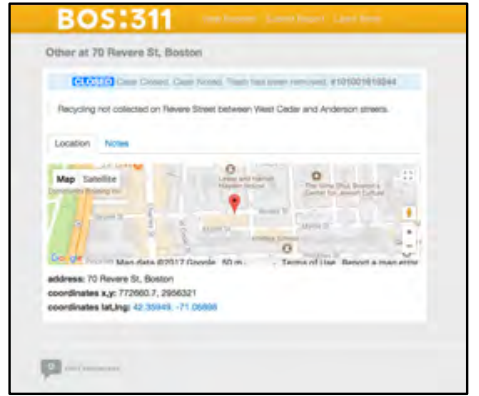

2. Text and Map

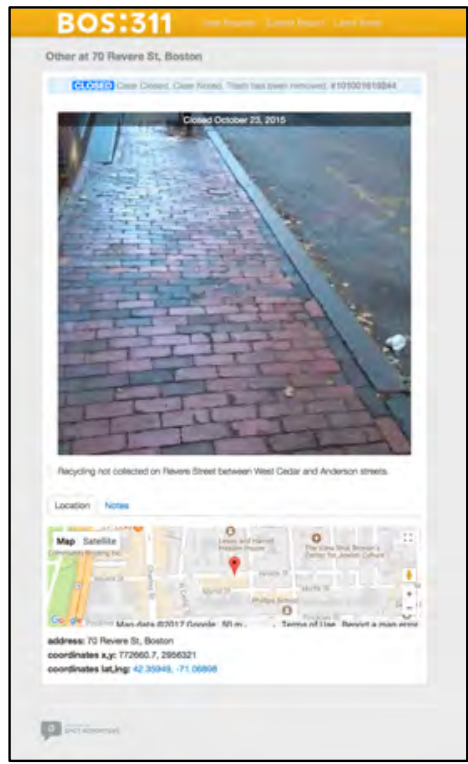

4. Text, Map, and Closed Photo

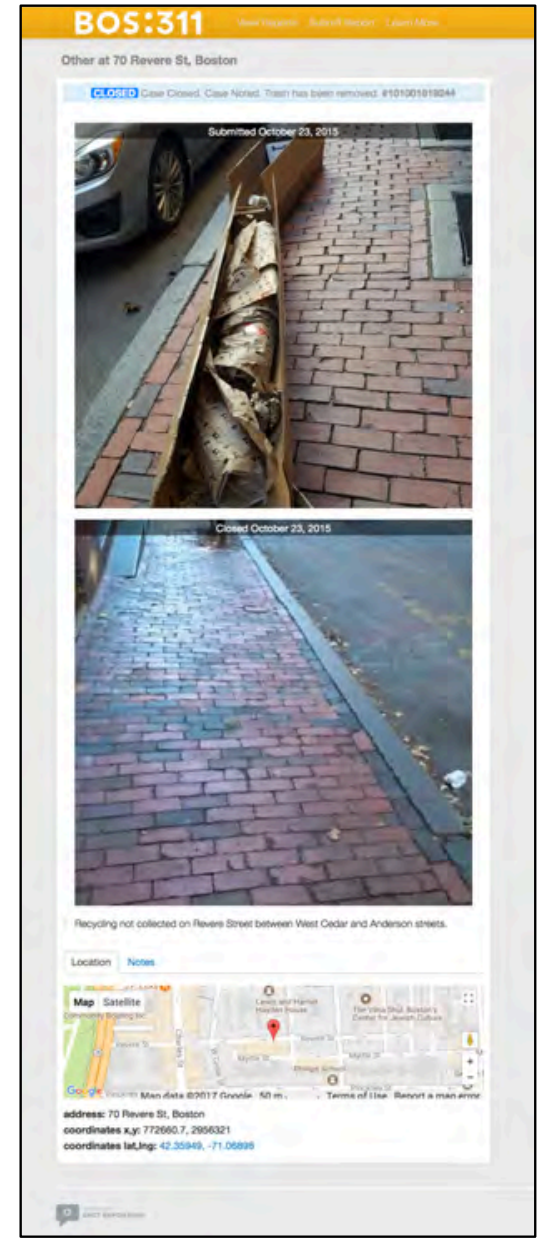

5. Text, Map, Open Photo, and Closed Photo

Figure A1: Screenshots of the BOS:311 website study, illustrating the 1) text only, 2) text and map, 3) text, map, and open photo, 4) text, map, and closed photo, and 5) text, map, open, and closed photo conditions (Appendix Study).

4.1.2. Results: We modeled responses to the composite trust, ANES domestic spending, composite support, and support for tax increase measures as a function of the randomly assigned experimental conditions and the demographic control questions. We additionally controlled for the duration of each participant's exposure to the survey questions and web pages, fixed effects for the randomly assigned service requests, and indicator variables identifying participants who opted out of answering the income and political ideology questions. As summarized in Table A6, OLS models revealed a general pattern, in which relative to the information-only baseline, the addition of a map that made tangible the location of the work performed, and the addition of photos, illustrating the work that was requested and performed, significantly increased trust in and support for the government. Adding a map increased support for the 
government $(\beta=0.26 ; p<0.05)$ and support for tax increases $(\beta=0.470, p<0.01)$, though it did not significantly increase trust $(\beta=0.165, p=0.20)$ or trust in government spending $(\beta=0.124, p=0.17)$. Additionally appending photos documenting the work being requested and performed did lead to higher levels of trust $(\beta=0.219, p<0.05)$, increased support for the government $(\beta=0.279, p<0.05)$, and greater support for tax increases $(\beta=0.42, p<0.05)$, without affecting trust in government spending $(\beta=0.137, p$ $=0.16$ ). Interestingly, the inclusion of photos documenting work requested without photos of the work performed, or the inclusion of photos documenting the work that was performed without photos of the work that was requested generally had no effect on levels of trust and support. The sole exception is that the inclusion of a photo showing work that had been performed led to a marginal increase in support for tax increases $(\beta=0.303, p<0.10)$. This pattern of results suggests that although operational transparency that creates a perceptible representation of the work being performed can improve trust in and support for the government, citizens appear unmoved by transparency that doesn't provide a window into the full exchange.

\begin{tabular}{|c|c|c|c|c|}
\hline & (1) & (2) & (3) & (4) \\
\hline & $\begin{array}{c}\text { Composite } \\
\text { Trust }\end{array}$ & $\begin{array}{c}\text { Trust in } \\
\text { Government } \\
\text { Spending } \\
\end{array}$ & $\begin{array}{l}\text { Composite } \\
\text { Support }\end{array}$ & $\begin{array}{l}\text { Support for } \\
\text { Tax Increases }\end{array}$ \\
\hline Text and map indicator & $\begin{array}{c}0.165 \\
(0.107)\end{array}$ & $\begin{array}{c}0.124 \\
(0.089)\end{array}$ & $\begin{array}{l}0.263^{* *} \\
(0.116)\end{array}$ & $\begin{array}{c}0.470^{* \star *} \\
(0.171)\end{array}$ \\
\hline Text, map, open and closed photos indicator & $\begin{array}{l}0.219^{* *} \\
(0.109)\end{array}$ & $\begin{array}{c}0.137 \\
(0.096)\end{array}$ & $\begin{array}{l}0.279^{* *} \\
(0.111)\end{array}$ & $\begin{array}{l}0.420^{* *} \\
(0.184)\end{array}$ \\
\hline Text, map, and open photo indicator & $\begin{array}{c}0.089 \\
(0.106)\end{array}$ & $\begin{array}{l}0.080 \\
(0.091)\end{array}$ & $\begin{array}{c}0.039 \\
(0.109)\end{array}$ & $\begin{array}{c}0.203 \\
(0.179)\end{array}$ \\
\hline Text, map, and closed photo indicator & $\begin{array}{l}-0.064 \\
(0.102)\end{array}$ & $\begin{array}{l}-0.050 \\
(0.090)\end{array}$ & $\begin{array}{c}0.001 \\
(0.118)\end{array}$ & $\begin{array}{l}0.303^{*} \\
(0.177)\end{array}$ \\
\hline Education & $\begin{array}{c}0.085^{* \star *} \\
(0.026)\end{array}$ & $\begin{array}{c}0.036 \\
(0.023)\end{array}$ & $\begin{array}{l}0.055^{* *} \\
(0.028)\end{array}$ & $\begin{array}{c}0.110^{* * *} \\
(0.041)\end{array}$ \\
\hline Minority & $\begin{array}{l}-0.011 \\
(0.101)\end{array}$ & $\begin{array}{l}-0.027 \\
(0.091)\end{array}$ & $\begin{array}{c}0.135 \\
(0.101)\end{array}$ & $\begin{array}{c}0.093 \\
(0.175)\end{array}$ \\
\hline Female & $\begin{array}{l}-0.067 \\
(0.069)\end{array}$ & $\begin{array}{c}0.042 \\
(0.063)\end{array}$ & $\begin{array}{c}0.093 \\
(0.075)\end{array}$ & $\begin{array}{c}0.048 \\
(0.114)\end{array}$ \\
\hline Political ideology & $\begin{array}{l}0.036 \\
(0.035)\end{array}$ & $\begin{array}{l}-0.019 \\
(0.031)\end{array}$ & $\begin{array}{c}-0.181^{* * *} \\
(0.039)\end{array}$ & $\begin{array}{c}-0.199^{* * *} \\
(0.056)\end{array}$ \\
\hline Missing ideology & $\begin{array}{l}0.525^{*} \\
(0.281)\end{array}$ & $\begin{array}{l}0.599^{* *} \\
(0.239)\end{array}$ & $\begin{array}{l}0.481^{*} \\
(0.258)\end{array}$ & $\begin{array}{c}1.181^{* \star *} \\
(0.419)\end{array}$ \\
\hline Income & $\begin{array}{c}0.009 \\
(0.010)\end{array}$ & $\begin{array}{c}0.003 \\
(0.008)\end{array}$ & $\begin{array}{l}-0.015 \\
(0.010)\end{array}$ & $\begin{array}{l}-0.010 \\
(0.016)\end{array}$ \\
\hline Missing income & $\begin{array}{l}-0.350 \\
(0.254)\end{array}$ & $\begin{array}{c}0.130 \\
(0.194)\end{array}$ & $\begin{array}{l}-0.440 \\
(0.359)\end{array}$ & $\begin{array}{l}0.795^{*} \\
(0.426)\end{array}$ \\
\hline Age & $\begin{array}{c}0.003 \\
(0.029)\end{array}$ & $\begin{array}{l}-0.038 \\
(0.025)\end{array}$ & $\begin{array}{c}0.003 \\
(0.032)\end{array}$ & $\begin{array}{c}0.051 \\
(0.053)\end{array}$ \\
\hline Party affiliation & $\begin{array}{l}0.006 \\
(0.033)\end{array}$ & $\begin{array}{l}0.048 \\
(0.030)\end{array}$ & $\begin{array}{c}0.133^{* * *} \\
(0.035)\end{array}$ & $\begin{array}{l}0.109^{* *} \\
(0.054)\end{array}$ \\
\hline Duration & $\begin{array}{c}0.000 \\
(0.000)\end{array}$ & $\begin{array}{l}-0.000 \\
(0.000)\end{array}$ & $\begin{array}{c}0.000 \\
(0.000)\end{array}$ & $\begin{array}{l}-0.000 \\
(0.000)\end{array}$ \\
\hline Constant & $\begin{array}{r}-1.115^{* *} \\
(0.483)\end{array}$ & $\begin{array}{c}1.675^{* * *} \\
(0.426)\end{array}$ & $\begin{array}{l}-0.895 \\
(0.543)\end{array}$ & $\begin{array}{c}2.583^{* \star \star} \\
(0.958)\end{array}$ \\
\hline $\begin{array}{l}\text { Observations } \\
\text { R-squared }\end{array}$ & $\begin{array}{c}432 \\
0.194\end{array}$ & $\begin{array}{c}432 \\
0.215\end{array}$ & $\begin{array}{c}432 \\
0.486\end{array}$ & $\begin{array}{c}432 \\
0.341\end{array}$ \\
\hline
\end{tabular}

Table A6: Making tangible the location where work was performed and showing the work that is performed increases trust in and support for government. Revealing images of the work requested, without imagery of the work performed, or revealing images of the work performed, without imagery of the work requested, does not have the same positive effects (Appendix Study). All columns additionally include indicator variables for the service requests shown to each participant. *,**, and *** indicate significance at the $10 \%, 5 \%$, and $1 \%$ levels, respectively, relative to the baseline, "text only" condition. Robust standard errors are presented in parentheses. 


\section{Appendix Study 2: Manipulating the mechanisms underlying the effects}

The results presented in Study 3 demonstrate that operational transparency increases willingness to engage with a responsive government through two causal pathways. First, operational transparency increases perceptions that the government is an effortful engagement partner, increasing feelings of appreciation and trust in government. Second, operational transparency increases perceptions that engaging with government is impactful, bolstering positivity toward oneself for engaging. In this supplemental study, we replicate the design of Study 3 in the $80 \%$ responsiveness condition, using messaging to directly manipulate perceived effort and perceived impact in a 2(transparency: non-transparent, transparent) $\mathrm{x}$ 2(messaging: none, low effort and impact messaging) design.

5.1.1 Participants. 3,000 participants residing in the United States $\left(49.7 \%\right.$ female, $\left.M_{\text {age }}=35.58\right)$ were recruited on Prolific, an online research platform, to participate in a five-minute research study on perceptions of local government in exchange for $\$ 1.00$. We intended to recruit 3,000 participants, in order to reach a minimum of 700 participants in each of the study's four experimental conditions after excluding those who failed the attention check. 106 participants failed to correctly answer the attention check question, resulting in a final sample of 2,894 participants (50.2\% female, $\left.M_{\mathrm{age}}=35.69\right)$.

\begin{tabular}{|c|c|c|c|c|c|c|c|c|}
\hline & \multicolumn{2}{|c|}{ No messaging } & \multicolumn{2}{|c|}{ Messaging } & \multirow[b]{2}{*}{ (A) } & \multirow[b]{2}{*}{ (B) } & \multirow[b]{2}{*}{ (C) } & \multirow[b]{2}{*}{ (D) } \\
\hline & $(1)$ & $(2)$ & (3) & $(4)$ & & & & \\
\hline & $\begin{array}{c}\text { Blind } \\
(n=725)\end{array}$ & $\begin{array}{c}\text { Transparent } \\
(n=716)\end{array}$ & $\begin{array}{l}\text { Blind. } \\
(n=728)\end{array}$ & $\begin{array}{c}\text { Transparent } \\
(n=725)\end{array}$ & $(1)=(2)$ & $(3)=(4)$ & $(1)=(3)$ & $(2)=(4)$ \\
\hline Perceived effort & 5.49 & 5.82 & 4.51 & 4.98 & $* * *$ & $* * *$ & $* * *$ & $* * *$ \\
\hline Appreciate government & 5.64 & 6.05 & 4.09 & 4.90 & $* * *$ & $* * *$ & $* * *$ & $* * *$ \\
\hline Trust government & 5.25 & 5.36 & 4.57 & 4.90 & ** & $* * *$ & $* * *$ & $* * *$ \\
\hline Support government & 5.23 & 5.21 & 5.00 & 5.00 & & & $* * *$ & $* * *$ \\
\hline Perceived impact & 5.36 & 5.67 & 4.32 & 4.81 & $* * *$ & $* * *$ & $* * *$ & $* * *$ \\
\hline Positiity toward self & 5.67 & 6.02 & 4.32 & 4.89 & $* * *$ & $* * *$ & $* * *$ & $* * *$ \\
\hline Willingness to engage & 6.20 & 6.31 & 5.58 & 5.88 & * & $* * *$ & $* * *$ & $* * *$ \\
\hline Efficacy & 5.29 & 5.25 & 5.22 & 5.30 & & & & \\
\hline
\end{tabular}

Table A7: Comparisons of primary dependent measures by condition. The main effects of operational transparency hold A) in the no messaging condition, and B) in the messaging condition. Moreover, the main effects of the messaging hold in the C) blind and D) transparent conditions. Unlike in Study 3, we note that efficacy didn't vary across conditions, as all participants in this study experienced $80 \%$ responsiveness (Appendix Study 2). * **, and *** signify significance at the $10 \%, 5 \%$ and $1 \%$ levels, respectively, for the contrast indicated in the column header.

\subsubsection{Design and procedure. Consistent with Study 3, after reading a description of the Citizen's}

Connect app and experiencing the $80 \%$ responsiveness manipulation, participants were asked to imagine 
that they had seen trash on the sidewalk, and that they had used the Citizen's Connect app to report it to the Boston local government. Then, on the following screen, participants were informed that the next day they saw a response posted in the app. Participants who were randomly assigned to experience low effort and impact messaging read, "In addressing the issue, the public works team didn't spend much time planning and didn't physically exert themselves, " and, "Instead of reporting the issue to the government, you could have picked up the trash yourself," which pre-tests revealed had a significant effect on perceived effort and perceived impact. The presentation order of these messages was counterbalanced. Then, as in Study 3, participants were randomly assigned to see a non-transparent or transparent response to their service request, before answering a battery of questions assessing their perceptions of the Boston government and their willingness to engage with it.

\begin{tabular}{|c|c|c|c|c|c|c|c|c|}
\hline & $\begin{array}{c}(1) \\
\text { Engage }\end{array}$ & $\begin{array}{c}(2) \\
\text { Effort }\end{array}$ & $\begin{array}{c}\text { (3) } \\
\text { Appreciation }\end{array}$ & $\begin{array}{c}\text { (4) } \\
\text { Trust }\end{array}$ & $\begin{array}{c}\text { (5) } \\
\text { Support }\end{array}$ & $\begin{array}{c}\text { (6) } \\
\text { Support }\end{array}$ & $\begin{array}{c}(7) \\
\text { Impact }\end{array}$ & $\begin{array}{c}\text { (8) } \\
\text { Positivity }\end{array}$ \\
\hline Transparency indicator & $\begin{array}{l}0.192^{* * *} \\
{[0.048]}\end{array}$ & $\begin{array}{l}0.398^{* * *} \\
{[0.044]}\end{array}$ & $\begin{array}{l}0.608^{* * *} \\
{[0.057]}\end{array}$ & $\begin{array}{l}0.212^{* * *} \\
{[0.045]}\end{array}$ & $\begin{array}{l}-0.035 \\
{[0.043]}\end{array}$ & $\begin{array}{l}-0.095^{\star *} \\
{[0.041]}\end{array}$ & $\begin{array}{l}0.401^{* * *} \\
{[0.045]}\end{array}$ & $\begin{array}{c}0.456^{* * *} \\
{[0.053]}\end{array}$ \\
\hline Messaging indicator & $\begin{array}{l}-0.525^{* * *} \\
{[0.048]}\end{array}$ & $\begin{array}{c}-0.904^{* * *} \\
{[0.044]}\end{array}$ & $\begin{array}{c}-1.351^{* * *} \\
{[0.057]}\end{array}$ & $\begin{array}{c}-0.570^{* * *} \\
{[0.045]}\end{array}$ & $\begin{array}{c}-0.235^{* * *} \\
{[0.043]}\end{array}$ & $\begin{array}{l}-0.072^{*} \\
{[0.042]}\end{array}$ & $\begin{array}{c}-0.957^{* * *} \\
{[0.046]}\end{array}$ & $\begin{array}{c}-1.238^{* * *} \\
{[0.054]}\end{array}$ \\
\hline Trust & & & & & & $\begin{array}{l}0.286^{* * *} \\
{[0.022]}\end{array}$ & & \\
\hline Female indicator & $\begin{array}{l}0.281^{* * *} \\
{[0.051]}\end{array}$ & $\begin{array}{l}0.157^{* * *} \\
{[0.046]}\end{array}$ & $\begin{array}{l}0.239^{* * *} \\
{[0.059]}\end{array}$ & $\begin{array}{l}0.152^{* * *} \\
{[0.047]}\end{array}$ & $\begin{array}{c}0.113^{* * *} \\
{[0.043]}\end{array}$ & $\begin{array}{l}0.069^{*} \\
{[0.041]}\end{array}$ & $\begin{array}{l}0.092^{* *} \\
{[0.047]}\end{array}$ & $\begin{array}{c}0.147^{\star * *} \\
{[0.055]}\end{array}$ \\
\hline Age & $\begin{array}{c}0.001 \\
{[0.005]}\end{array}$ & $\begin{array}{c}-0.003 \\
{[0.005]}\end{array}$ & $\begin{array}{l}-0.006 \\
{[0.006]}\end{array}$ & $\begin{array}{l}-0.005 \\
{[0.005]}\end{array}$ & $\begin{array}{l}-0.010^{* *} \\
{[0.004]}\end{array}$ & $\begin{array}{l}-0.009^{*} \\
{[0.005]}\end{array}$ & $\begin{array}{c}0.002 \\
{[0.005]}\end{array}$ & $\begin{array}{c}0.004 \\
{[0.005]}\end{array}$ \\
\hline $\mathrm{Age}^{2}$ & $\begin{array}{c}0.000 \\
{[0.000]}\end{array}$ & $\begin{array}{l}0.000^{*} \\
{[0.000]}\end{array}$ & $\begin{array}{c}0.000 \\
{[0.000]}\end{array}$ & $\begin{array}{c}0.000 \\
{[0.000]}\end{array}$ & $\begin{array}{c}0.000 \\
{[0.000]}\end{array}$ & $\begin{array}{c}0.000 \\
{[0.000]}\end{array}$ & $\begin{array}{c}0.000 \\
{[0.000]}\end{array}$ & $\begin{array}{c}0.000 \\
{[0.000]}\end{array}$ \\
\hline Education level & $\begin{array}{c}0.014 \\
{[0.019]}\end{array}$ & $\begin{array}{l}-0.005 \\
{[0.017]}\end{array}$ & $\begin{array}{c}0.016 \\
{[0.022]}\end{array}$ & $\begin{array}{c}0.009 \\
{[0.017]}\end{array}$ & $\begin{array}{c}0.011 \\
{[0.017]}\end{array}$ & $\begin{array}{c}0.008 \\
{[0.016]}\end{array}$ & $\begin{array}{r}-0.000 \\
{[0.017]}\end{array}$ & $\begin{array}{c}-0.001 \\
{[0.021]}\end{array}$ \\
\hline Income level & $\begin{array}{l}0.021^{*} \\
{[0.011]}\end{array}$ & $\begin{array}{c}0.012 \\
{[0.010]}\end{array}$ & $\begin{array}{l}0.029^{* *} \\
{[0.013]}\end{array}$ & $\begin{array}{c}0.013 \\
{[0.010]}\end{array}$ & $\begin{array}{c}-0.006 \\
{[0.010]}\end{array}$ & $\begin{array}{c}-0.009 \\
{[0.009]}\end{array}$ & $\begin{array}{c}0.009 \\
{[0.010]}\end{array}$ & $\begin{array}{l}0.028^{* *} \\
{[0.012]}\end{array}$ \\
\hline Political knowledge & $\begin{array}{c}-0.013 \\
{[0.041]}\end{array}$ & $\begin{array}{c}0.001 \\
{[0.036]}\end{array}$ & $\begin{array}{l}-0.026 \\
{[0.047]}\end{array}$ & $\begin{array}{c}0.003 \\
{[0.038]}\end{array}$ & $\begin{array}{c}-0.043 \\
{[0.037]}\end{array}$ & $\begin{array}{c}-0.044 \\
{[0.035]}\end{array}$ & $\begin{array}{c}0.053 \\
{[0.039]}\end{array}$ & $\begin{array}{c}-0.034 \\
{[0.047]}\end{array}$ \\
\hline Political interest & $\begin{array}{c}0.138^{* * *} \\
{[0.034]}\end{array}$ & $\begin{array}{c}0.043 \\
{[0.031]}\end{array}$ & $\begin{array}{l}0.085^{\star *} \\
{[0.040]}\end{array}$ & $\begin{array}{c}0.033 \\
{[0.032]}\end{array}$ & $\begin{array}{l}0.086^{* * *} \\
{[0.032]}\end{array}$ & $\begin{array}{l}0.077^{\star *} \\
{[0.030]}\end{array}$ & $\begin{array}{c}0.051 \\
{[0.033]}\end{array}$ & $\begin{array}{c}0.108^{* * *} \\
{[0.040]}\end{array}$ \\
\hline Political ideology & $\begin{array}{c}-0.089^{* * *} \\
{[0.034]}\end{array}$ & $\begin{array}{c}-0.016 \\
{[0.033]}\end{array}$ & $\begin{array}{l}-0.008 \\
{[0.043]}\end{array}$ & $\begin{array}{c}0.017 \\
{[0.033]}\end{array}$ & $\begin{array}{c}-0.251^{* * *} \\
{[0.034]}\end{array}$ & $\begin{array}{c}-0.256^{* * *} \\
{[0.031]}\end{array}$ & $\begin{array}{c}0.040 \\
{[0.034]}\end{array}$ & $\begin{array}{c}0.075^{\star} \\
{[0.039]}\end{array}$ \\
\hline Constant & $\begin{array}{l}5.481^{* * *} \\
{[0.196]}\end{array}$ & $\begin{array}{c}5.215^{* * *} \\
{[0.166]}\end{array}$ & $\begin{array}{c}5.147^{* * *} \\
{[0.214]}\end{array}$ & $\begin{array}{l}5.096^{* * *} \\
{[0.174]}\end{array}$ & $\begin{array}{c}6.212^{* * *} \\
{[0.164]}\end{array}$ & $\begin{array}{c}4.757^{* * *} \\
{[0.193]}\end{array}$ & $\begin{array}{c}4.595^{* * *} \\
{[0.174]}\end{array}$ & $\begin{array}{c}4.803^{* * *} \\
{[0.196]}\end{array}$ \\
\hline Observations & 2,845 & 2,854 & 2,851 & 2,854 & 2,854 & 2,854 & 2,853 & 2,850 \\
\hline R-squared & 0.083 & 0.168 & 0.203 & 0.079 & 0.184 & 0.258 & 0.175 & 0.196 \\
\hline
\end{tabular}

Table A8: Operational transparency increases, and low effort and impact messaging diminishes, perceived effort, feelings of government appreciation, trust in the government, the perception that engaging with the government is impactful, and positive feelings toward oneself for engaging, and trust is positively associated with support (Appendix Study 2). Robust standard errors are provided in parentheses. All models additionally include an indicator variable for the respondent's stated political party. $*, * *$, and *** signify significance at the $10 \%, 5 \%$ and $1 \%$ levels, respectively, relative to the baseline non-transparent, no messaging condition. 
5.1.3. Survey and control measures. We asked participants the same battery of questions used in Study 3, and we aggregate measures in the same way. Consistent with Study 3, we note that all multi-item measures, including perceived effort $(\alpha=0.921)$, appreciation $(\alpha=0.975)$, trust $(\alpha=0.928)$, support $(\alpha=0.823)$ and impact $(\alpha=0.844)$, showed a high degree of internal consistency. Summary statistics by condition are provided in Table A7.

5.1.4. Empirical approach. We analyze the results of the experiment in two stages. First, we use OLS regression to model the main effects of operational transparency and low effort and impact messaging on the primary dependent measures: willingness to engage, perceived effort, appreciation, trust, support, impact, and feelings of positivity directed toward oneself for engaging. In Table A8. we observe main effects of transparency on willingness to engage (coefficient $=0.192, p<0.01$ ), perceived effort (coefficient $=0.398, p<0.01)$, appreciation (coefficient $=0.608, p<0.01)$, trust (coefficient $=0.212, p<0.01)$, impact (coefficient $=0.401, p<0.01)$, and positivity (coefficient $=0.456, p<0.01)$. We also observe main effects of messaging, which reduced intended behaviors and perceptions across these same dimensions, including willingness to engage (coefficient $=-0.525, p<0.01$ ), perceived effort (coefficient $=-0.904, p<0.01$ ), appreciation (coefficient $=1.351, p<0.01)$, trust (coefficient $=-0.570, p<0.01)$, impact (coefficient $=-0.957$, $p<0.01$ ), and positivity (coefficient $=-1.238, p<0.01$ ), suggesting the messaging manipulation was experienced as intended.

Second, in Table A9, we replicate the same analysis, incorporating an interaction between transparency and messaging. This set of specifications enables us to accomplish three things. First, we can examine a more controlled analysis of the effects of operational transparency in the absence of messaging. Consistent with Study 3, we found converging evidence that operational transparency increases willingness to engage (coefficient $=0.103, p<0.10$ ), perceived effort (coefficient $=0.336, p<0.01$ ), appreciation (coefficient $=0.413, p<0.01$ ), trust (coefficient $=0.105, p<0.10)$, impact (coefficient $=0.317, p<0.01$ ), and positivity (coefficient $=0.337, p<0.01$ ). Second, we observe main effects of messaging in the absence of transparency, which again, reduced perceptions across these same dimensions, including willingness to engage (coefficient $=-0.614, p<0.01$ ), perceived effort (coefficient $=-0.966, p<0.01$ ), appreciation (coefficient $=1.546, p<0.01)$, trust (coefficient $=-0.678, p<0.01)$, impact (coefficient $=-1.041, p<0.01)$, and positivity (coefficient $=-1.356, p<0.01$ ). Third and finally, the interaction model enables us to test whether the effects of operational transparency on these dependent measures depends on the messaging condition - whether the effects of operational transparency on trust and engagement are stronger or weaker when people have low perceptions of the government as an effortful and impactful engagement partner. The results reveal positive and significant interactions for most measures, including willingness to engage (coefficient $=0.178, p<0.10)$, appreciation $($ coefficient $=0.390, p<0.01)$, trust $($ coefficient $=0.215, p<0.05)$, 
impact (coefficient $=0.167, p<0.10$ ), and positivity (coefficient $=0.237, p<0.05$ ). The coefficient on effort is directionally consistent with the other results, but it is statistically insignificant (coefficient $=0.124$, $p=0.159)$.

Taken together, these results provide converging evidence consistent with the results of Study 3, but they also reveal that operational transparency may be an especially successful strategy for increasing trust and engagement in contexts where people have low perceptions of the organization's efforts and the impact of engaging with it.

\begin{tabular}{|c|c|c|c|c|c|c|c|c|}
\hline & $\begin{array}{c}(1) \\
\text { Engage } \\
\end{array}$ & $\begin{array}{c}(2) \\
\text { Effort }\end{array}$ & $\begin{array}{c}(3) \\
\text { Appreciation } \\
\end{array}$ & $\begin{array}{c}(4) \\
\text { Trust } \\
\end{array}$ & $\begin{array}{c}\text { (5) } \\
\text { Support }\end{array}$ & $\begin{array}{c}(6) \\
\text { Support }\end{array}$ & $\begin{array}{c}(7) \\
\text { Impact } \\
\end{array}$ & $\begin{array}{c}(8) \\
\text { Positivity }\end{array}$ \\
\hline Transparency indicator & $\begin{array}{c}0.103^{*} \\
{[0.058]}\end{array}$ & $\begin{array}{c}0.336^{\star \star \star} \\
{[0.055]}\end{array}$ & $\begin{array}{c}0.413^{\star \star \star} \\
{[0.066]}\end{array}$ & $\begin{array}{l}0.105^{\star} \\
{[0.057]}\end{array}$ & $\begin{array}{c}-0.047 \\
{[0.059]}\end{array}$ & $\begin{array}{c}-0.077 \\
{[0.056]}\end{array}$ & $\begin{array}{c}0.317^{\star \star \star} \\
{[0.059]}\end{array}$ & $\begin{array}{c}0.337^{\star * *} \\
{[0.066]}\end{array}$ \\
\hline Messaging indicator & $\begin{array}{c}-0.614^{\star * *} \\
{[0.072]}\end{array}$ & $\begin{array}{c}-0.966^{\star * *} \\
{[0.068]}\end{array}$ & $\begin{array}{c}-1.546^{\star * *} \\
{[0.087]}\end{array}$ & $\begin{array}{c}-0.678^{* \star *} \\
{[0.068]}\end{array}$ & $\begin{array}{c}-0.247^{\star \star *} \\
{[0.060]}\end{array}$ & $\begin{array}{c}-0.053 \\
{[0.059]}\end{array}$ & $\begin{array}{c}-1.041^{* \star *} \\
{[0.069]}\end{array}$ & $\begin{array}{c}-1.356^{* * *} \\
{[0.082]}\end{array}$ \\
\hline Transparency $\mathrm{x}$ messaging & $\begin{array}{l}0.178^{*} \\
{[0.096]}\end{array}$ & $\begin{array}{c}0.124 \\
{[0.088]}\end{array}$ & $\begin{array}{c}0.390^{* * *} \\
{[0.113]}\end{array}$ & $\begin{array}{l}0.215^{\star *} \\
{[0.089]}\end{array}$ & $\begin{array}{c}0.025 \\
{[0.085]}\end{array}$ & $\begin{array}{c}-0.037 \\
{[0.082]}\end{array}$ & $\begin{array}{c}0.167^{\star} \\
{[0.090]}\end{array}$ & $\begin{array}{l}0.237^{\star *} \\
{[0.106]}\end{array}$ \\
\hline Trust & & & & & & $\begin{array}{c}0.286^{\star * *} \\
{[0.022]}\end{array}$ & & \\
\hline Female indicator & $\begin{array}{c}0.280^{\star * *} \\
{[0.051]}\end{array}$ & $\begin{array}{c}0.157^{\star * *} \\
{[0.046]}\end{array}$ & $\begin{array}{c}0.237^{\star \star *} \\
{[0.059]}\end{array}$ & $\begin{array}{c}0.151^{\star \star \star} \\
{[0.047]}\end{array}$ & $\begin{array}{c}0.112^{\star \star *} \\
{[0.043]}\end{array}$ & $\begin{array}{c}0.069^{*} \\
{[0.041]}\end{array}$ & $\begin{array}{l}0.092^{*} \\
{[0.047]}\end{array}$ & $\begin{array}{c}0.146^{\star \star \star} \\
{[0.055]}\end{array}$ \\
\hline Age & $\begin{array}{c}0.001 \\
{[0.005]}\end{array}$ & $\begin{array}{c}-0.003 \\
{[0.005]}\end{array}$ & $\begin{array}{l}-0.006 \\
{[0.006]}\end{array}$ & $\begin{array}{c}-0.005 \\
{[0.005]}\end{array}$ & $\begin{array}{l}-0.010^{\star *} \\
{[0.004]}\end{array}$ & $\begin{array}{l}-0.009^{*} \\
{[0.005]}\end{array}$ & $\begin{array}{c}0.002 \\
{[0.005]}\end{array}$ & $\begin{array}{c}0.004 \\
{[0.005]}\end{array}$ \\
\hline $\mathrm{Age}^{2}$ & $\begin{array}{c}0.000 \\
{[0.000]}\end{array}$ & $\begin{array}{l}0.000^{*} \\
{[0.000]}\end{array}$ & $\begin{array}{c}0.000 \\
{[0.000]}\end{array}$ & $\begin{array}{c}0.000 \\
{[0.000]}\end{array}$ & $\begin{array}{c}0.000 \\
{[0.000]}\end{array}$ & $\begin{array}{c}0.000 \\
{[0.000]}\end{array}$ & $\begin{array}{c}0.000 \\
{[0.000]}\end{array}$ & $\begin{array}{c}0.000 \\
{[0.000]}\end{array}$ \\
\hline Education level & $\begin{array}{c}0.014 \\
{[0.019]}\end{array}$ & $\begin{array}{l}-0.005 \\
{[0.017]}\end{array}$ & $\begin{array}{c}0.014 \\
{[0.022]}\end{array}$ & $\begin{array}{c}0.008 \\
{[0.017]}\end{array}$ & $\begin{array}{c}0.011 \\
{[0.017]}\end{array}$ & $\begin{array}{c}0.008 \\
{[0.016]}\end{array}$ & $\begin{array}{l}-0.001 \\
{[0.017]}\end{array}$ & $\begin{array}{c}-0.002 \\
{[0.021]}\end{array}$ \\
\hline Income level & $\begin{array}{l}0.020^{*} \\
{[0.011]}\end{array}$ & $\begin{array}{c}0.012 \\
{[0.010]}\end{array}$ & $\begin{array}{l}0.027^{* *} \\
{[0.013]}\end{array}$ & $\begin{array}{c}0.012 \\
{[0.010]}\end{array}$ & $\begin{array}{l}-0.006 \\
{[0.010]}\end{array}$ & $\begin{array}{l}-0.009 \\
{[0.009]}\end{array}$ & $\begin{array}{c}0.008 \\
{[0.010]}\end{array}$ & $\begin{array}{l}0.027^{* *} \\
{[0.012]}\end{array}$ \\
\hline Political knowledge & $\begin{array}{c}-0.015 \\
{[0.041]}\end{array}$ & $\begin{array}{l}-0.000 \\
{[0.036]}\end{array}$ & $\begin{array}{l}-0.029 \\
{[0.047]}\end{array}$ & $\begin{array}{c}0.001 \\
{[0.038]}\end{array}$ & $\begin{array}{c}-0.043 \\
{[0.037]}\end{array}$ & $\begin{array}{c}-0.043 \\
{[0.035]}\end{array}$ & $\begin{array}{c}0.052 \\
{[0.039]}\end{array}$ & $\begin{array}{c}-0.036 \\
{[0.047]}\end{array}$ \\
\hline Political interest & $\begin{array}{c}0.139^{* * *} \\
{[0.034]}\end{array}$ & $\begin{array}{c}0.044 \\
{[0.031]}\end{array}$ & $\begin{array}{l}0.087^{\star *} \\
{[0.040]}\end{array}$ & $\begin{array}{c}0.034 \\
{[0.031]}\end{array}$ & $\begin{array}{c}0.086^{* * *} \\
{[0.032]}\end{array}$ & $\begin{array}{l}0.076^{\star *} \\
{[0.030]}\end{array}$ & $\begin{array}{c}0.051 \\
{[0.033]}\end{array}$ & $\begin{array}{c}0.110^{* * *} \\
{[0.040]}\end{array}$ \\
\hline Political ideology & $\begin{array}{c}-0.087^{* * *} \\
{[0.034]}\end{array}$ & $\begin{array}{c}-0.015 \\
{[0.033]}\end{array}$ & $\begin{array}{l}-0.005 \\
{[0.043]}\end{array}$ & $\begin{array}{c}0.018 \\
{[0.033]}\end{array}$ & $\begin{array}{c}-0.251^{* * *} \\
{[0.034]}\end{array}$ & $\begin{array}{c}-0.256^{* * *} \\
{[0.031]}\end{array}$ & $\begin{array}{c}0.041 \\
{[0.034]}\end{array}$ & $\begin{array}{c}0.077^{*} \\
{[0.039]}\end{array}$ \\
\hline Constant & $\begin{array}{c}5.532^{\star * *} \\
{[0.200]}\end{array}$ & $\begin{array}{c}5.251^{\star \star *} \\
{[0.168]}\end{array}$ & $\begin{array}{c}5.258^{\star \star *} \\
{[0.214]}\end{array}$ & $\begin{array}{c}5.158^{\star \star *} \\
{[0.176]}\end{array}$ & $\begin{array}{c}6.219^{\star \star *} \\
{[0.166]}\end{array}$ & $\begin{array}{c}4.744^{\star \star *} \\
{[0.195]}\end{array}$ & $\begin{array}{c}4.643^{\star \star *} \\
{[0.176]}\end{array}$ & $\begin{array}{c}4.871^{\star * *} \\
{[0.198]}\end{array}$ \\
\hline Observations & 2,845 & 2,854 & 2,851 & 2,854 & 2,854 & 2,854 & 2,853 & 2,850 \\
\hline R-squared & 0.084 & 0.168 & 0.207 & 0.080 & 0.184 & 0.258 & 0.176 & 0.197 \\
\hline
\end{tabular}

Table A9: In the no messaging conditions, operational transparency increases perceived effort, feelings of government appreciation, trust in the government, the perception that engaging with the government is impactful, and positive feelings toward oneself for engaging, and trust is positively associated with support. In the no transparency condition, low effort and impact messaging diminishes these same perceptions. Importantly, for most contrasts there is a positive and significant interaction between transparency and messaging, suggesting the effects of transparency on trust and engagement are greater in contexts where perceptions of the government as an effortful and impactful engagement partner are low (Appendix Study 2). Robust standard errors are provided in parentheses. All models additionally include an indicator variable for the respondent's stated political party. $* * *$, and *** signify significance at the $10 \%, 5 \%$ and $1 \%$ levels, respectively, relative to the baseline non-transparent, no messaging condition. 